Bishop

HANNINGTON

解 


\section{0}

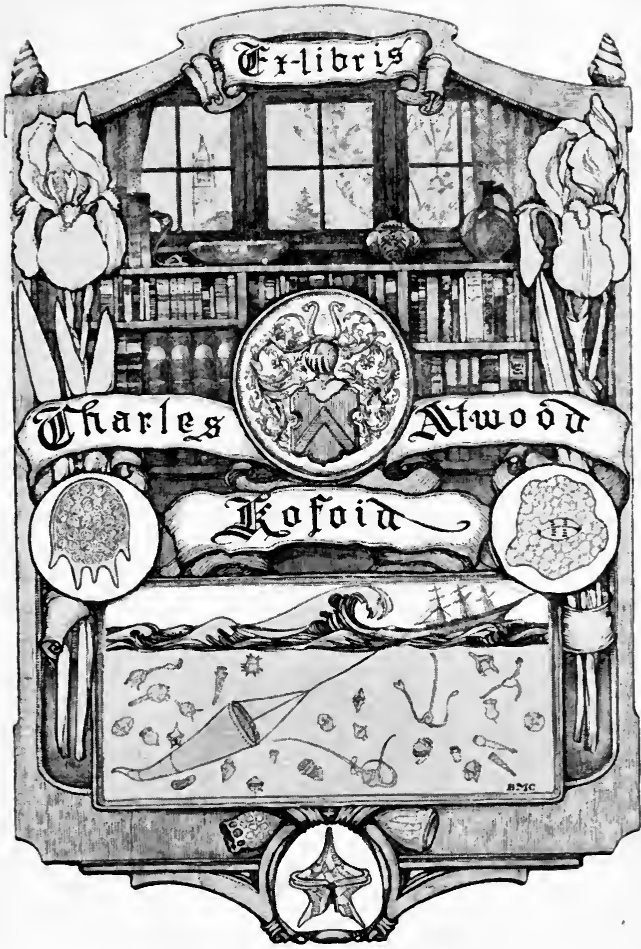




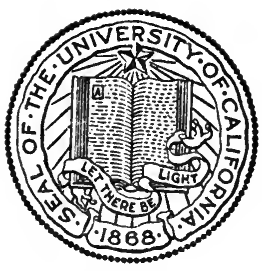

\title{
THE LIBRARY
}

OF

\section{THE UNIVERSITY}

OF CALIFORNIA

\author{
PRESENTED BY \\ PROF. CHARLES A. KOFOID AND \\ MRS. PRUDENCE W. KOFOID
}


- 


\section{BISHOP HANNINGTON}




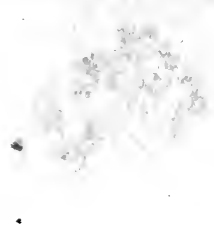




\section{Digitized by the Internet Archive in 2008 with funding from Microsoft Corporation}




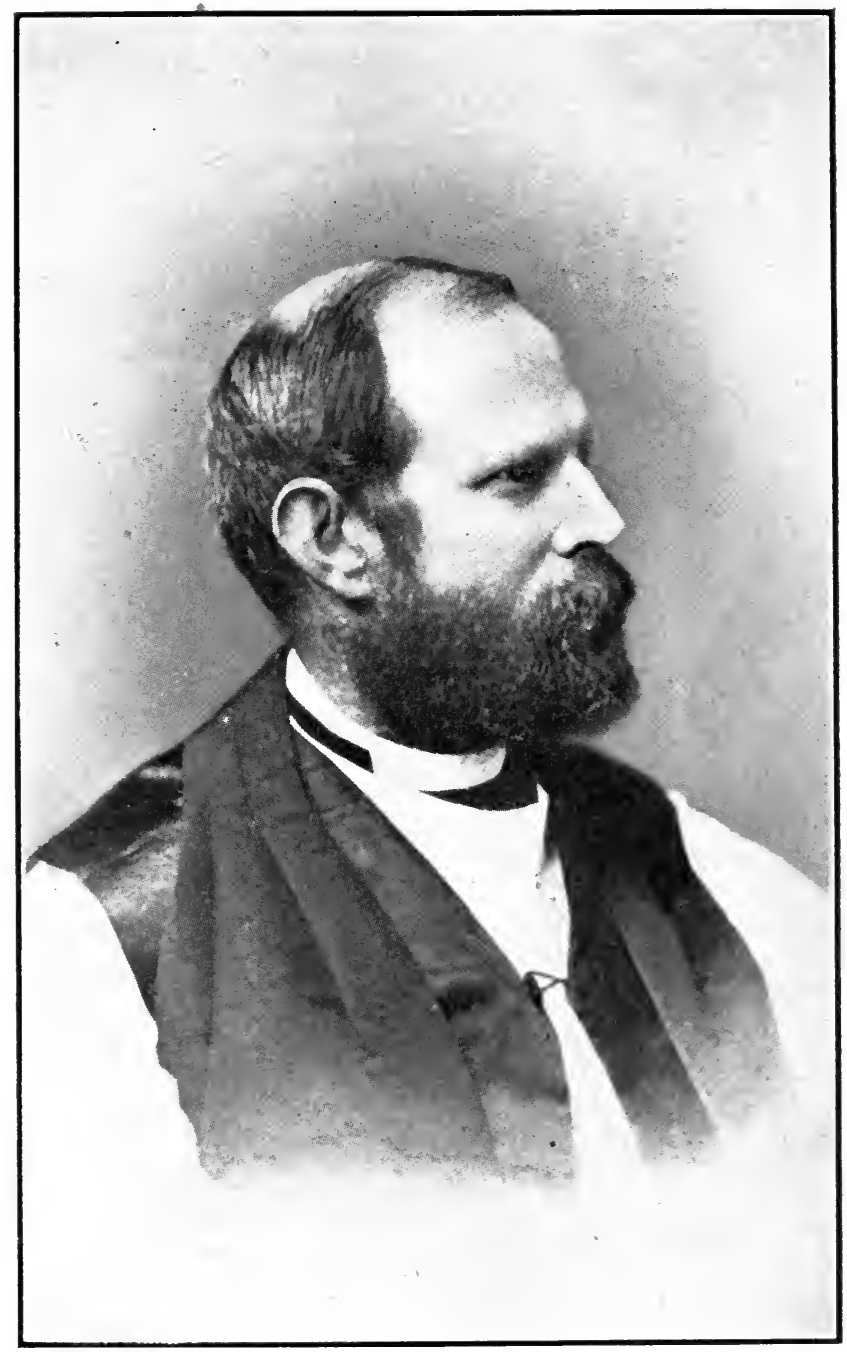

BISHOP HANNINGTON 


\section{B I S H O P}

\section{HANNINGTON}

\section{AND THE STORY OF THE UGANDA MISSION}

PREPARED BY

W. GRINTON BERRY, M.A.

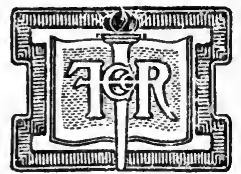

New York Chicago Toronto

Fleming H. Revell Company

LONDON AND EDINBURGH 



\section{BV 3625 $44 \mathrm{H}^{3}$}

\section{PREFACE}

$A$ BOUT a third of this little book is the work $A$ of Bishop Hannington himself. A most graphic, racy, and altogether charming volume entitled Peril and Adventure in Central Africa, consisting of a number of letters, with humorous illustrations, from the Bishop to his nephews in England, was published some years ago by the Religious Tract Society. A considerable portion of these letters has been incorporated in this book. The only regret of the reader will be that there is not more material from the vivid and glowing pen of the Bishop himself.

The compiler of this volume desires to acknowledge his special obligations to James Hannington : A History of His Life and Work, by the Rev. E. C. Dawson, M.A.; The Wonderful Story of Uganda, by the Rev. J. D. Mullins, M.A.; The History of the Church Missionary Society, in three volumes, by Mr. Eugene Stock; and the annual reports of the 


\section{PREFACE}

C.M.S. Mr. „Dawson's work is on a larger scale and more expensive than this little book. The object of the present compiler has been to produce a volume interesting to all the friends and supporters of missionary work, and specially adapted for wide-spread circulation among the older members of Sunday Schools, in Bible Classes, Christian Endeavour Societies, and kindred organisations. The story which it has to tell is that of one of the most thrilling campaigns of the Gospel warfare in heathen lands.

W. GRINTON BERRY. 


\section{CONTENTS}

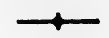

CHAP

I. 'A Gentreman at Largi' - •

II. The Story of Hannington's Conversion - 13

III. A Faithful Minister of the Word • 18

IV. The Early History of the Uganda Mission - 33

V. An Adventurous Journey : Hannington's NARRATIVE $\quad$ - $\quad$ - $\quad$ - 42

VI. At the Great Lake: Hannington's Narrative CONTINUED $\quad$ •

VII. The Darker Colours of the Picture - - II

VIII. Bishop of Eastern Equatorial Africa • $\quad$ I24

IX. The Last Journey • • • • • $\quad$ - I38

X. What had Happened in Uganda. • . I56

XI. The Martyrdom of Bishop Hannington • - 163

XII. The Story of Uganda since Hannington's DEATH • . . • .

The Religious Tract Society and the Uganda

MIssion • $\quad \cdot$ vii $\quad \cdot \quad \cdot \quad$ • 210 


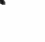




\section{BISHOP HANNINGTON}

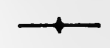

Chapter I

\section{'A GENTLEMAN AT LARGE'}

A headstrong, passionate Boy-'Mad Jim '-Cardinals and Chocolate Shops-His Mother's Influence-Becomes interested in Religion-Studying for the Ministry-His Mother's DeathOrdination.

T AMES HANNINGTON-appointed in the providence of God to a conspicuous place in the noble army of martyrs - was born on September 3, 1847, at Hurstpierpoint, a pretty little village in Sussex, some eight miles north-east of Brighton. He was the eighth child of his father, Charles Smith Hannington, who had a big drapery business in Brighton, and had just bought the property of St. George's at Hurstpierpoint.

The prosperity which the family enjoyed had been established by Smith Hannington, the grandfather of the future Bishop, who is described as

a shrewd man of business who never wanted a holiday and never thought that other people wanted 
one,' upright and stern, greatly loved and also greatly feared. The father was a man of somewhat similar temperament: he ruled his children with a firm hand, and was not sparing, when occasion rose, with the rod of correction.

James, 'a pickle of a boy,' always in scrapes, often emerging from them with impunity, sometimes not, was tenderly devoted, as a boy and always, to his mother, 'the gentlest mother, the sweetest, dearest mother that ever lived.' Her darling hand had always power to soothe him.

James was a headstrong, passionate boy, with a marked individuality, and perfectly fearless. His friend and biographer, Mr. Dawson, records how at the age of seven he clambered unnoticed up the mast of his father's yacht and was at last discovered high aloft, suspended on some projection by the seat of his trousers !

From very early he possessed a commanding -we do not say imperious-personality. At eleven years of age he made his first yachting trip with his elder brother in a hired cutter, and presently we discover him, with the calmest assurance, rebuking the captain and owner for broaching the wine locker and conniving at the projected theft of the cutter's sole silver spoon.

In one of his mad pranks, an attempt to blow up a wasp's nest by gunpowder, James lost the thumb of his left hand. It was by the mention of this personal defect, years afterwards, that 
Alexander Mackay, calmly and quietly, almost in isolation, working away at Uganda, was able to identify the tall Englishman who was reported by the natives to be approaching their country from the east.

The education of the warm-hearted and quicktempered boy was carried on at home, in a desultory and unsatisfactory way, until he was thirteen, when he was sent to a private institution, Temple School, at Brighton. He was even less in love with learning than the generality of boys, but he soon became very popular both with the other boys and the masters. He earned the nickname of 'Mad Jim' by such escapades as lighting a bonfire in the middle of his dormitory. One day he was caned more than a dozen times till his body smarted in every inch of it. Yet the heart of his moral character remained uncorrupted. He hated a lie, his word was as good as his bond, and he could stand up to a bully.

One day provoking a conflict with the tyrant of the school, Hannington was punished by the closingup of both his eyes and the temporary addition to his cranium of several egg-shaped excrescences.

His mother, to whom he had to pay his weekly visit that same day, was dreadfully shocked, and made him promise that he would not fight again. He promised, but, exasperated beyond his endurance by a bully who knew of this pledge, Hannington broke faith with his mother, gave the fellow a 
sound thrashing, and never again received provocation from that quarter.

Hannington, designed by his father for the counting-house at Brighton, left school at fifteen, and for the next six years on and off - very largely 'off' - he was learning his father's business.

Before settling down to business he was allowed the delights of a trip to Paris. The love of travel was born in Hannington. Before he had reached his majority he had done more travelling than falls to the average Englishman in the same station of life during a long lifetime, and he had had adventures galore. $\mathrm{He}$ was madly excited by the prospect of his visit to Paris: 'Visions of cardinals shut up in cages, of the horrors of revolutions, the Hunchback of Notre Dame, the Morgue, magnificent chocolate shops, all these and more confusedly floated through my brain.' The collocation of ' visions of cardinals' with ' magnificent chocolate shops' is eminently characteristic of a boy at once romantic and very natural.

At this time too he gave evidence of the possession of that rich fund of humour which helped him over many a difficult place in his journey through life. With regard to the proprietress of the boarding-house in which he stayed, he writes to his mother that 'Madame Boys is a kind, goodnatured, vulgar, blowing-up-servants little woman -all very desirable points to make me happy.' 
And he adds, 'I mean to bring you home six snails with rich plum pudding stuffing in them.'

Six months later he had another Continental trip, taking with him faculties of observation that were always wide awake. He notes, for example, that the regular professional gamblers at Wiesbaden were ' the ugliest set of people' that he ever saw in his life. He recollected these 'awfully eager' faces for many a day.

When only sixteen and a half years old Hannington acquired a commission as second lieutenant in the Ist Sussex Artillery Volunteers. Soldiering was much more in his line than business-was he not, once he was converted, and until he received the crown of martyrdom, a typical fighting Christian ? -and he made an excellent officer. He knew how to command and, not less, how to win the affections of his men. He was a splendid specimen of an English youth, standing, on his seventeenth birthday - as he records in his diary $-5 \mathrm{ft}$. Io in. high, and weighing II st. $6 \mathrm{lb}$. $\mathrm{He}$ was long, but his weight shows that he could not have been lean. 'He threw himself heart and soul into the work of his battery,' says Mr. Dawson, 'and received his commission as captain. He took a great deal of trouble in procuring for his men suitable recreation-rooms, and personally inspected, tested, and bought the various articles necessary for their equipment. He organised concerts, read- 
ings, and games, and made himself a prime favourite with the men under his charge.'

During a yachting tour in the North Sea and Baltic, Hannington gave another signal instance of his power of firm command. The crew had been getting very disorderly, and Hannington announced to them that in future any man breaking leave would be discharged. The first to offend was the captain; he went ashore, got hopelessly drunk, and overstayed his time. He imagined that he would easily make it up with the youth of nineteen who was his 'boss.' Mighty, then, was his astonishment and that of the whole crew when the captain was there and then sent ashore with all his belongings. There was no more trouble from disorderly seamen on that yacht!

Hannington had by this time clearly demonstrated his unfitness for business; his heart had never been in it ; even the father gave up hope of launching James out into a successful mercantile career; but what was to be done with the young man ? Echo answered, what?

Heart religion had up to this point borne no part in the life of James Hannington. He was a good, honest, truthful, manly lad, but, as he would probably himself have expressed it, religion was not in his line. The piety of his father was of a simple and somewhat severe character. Of his mother, James, as a lad of sixteen, wrote, 'Never was there such a churchgoer as my mother. She 
simply would go if it was possible.' This refers to times when the family were yachting, and Mrs. Hannington, in spite of the roughest weather, would insist on landing in order to go to church. On another occasion we read in Hannington's pocket-book: 'It blew furiously. No landing for church. Which means it did blow.' $\mathrm{He}$ concludes his diary for 1864 with the following verses :

' My heart, Lord, may I ever raise

To Thee in humble thanks and praise

For keeping me throughout this year.

Lord, guard and guide me while I'm here,

And when to die my time is come,

Oh, take me to Thy heavenly home.'

About this time he had a strange hankering after Roman Catholicism, probably dazzled by the powerful appeal of its ritual and ceremonies to the senses. This phase of his life was merely momentary. He soon came to the conclusion that 'the system was rotten.' At a later time, visiting the Pope's yacht, 'The Immaculate Conception,' at Civita Vecchia, he describes the vessel as "handsome outside, but very dirty in.' Hannington would have admitted that the words aptly enough described popery as well as the Pope's yacht.

The soul of a young lad is often a thing of mystery, and it is not easy to find the key of interpretation. While out shooting one day he lost his ring. He asked God that the ring might be found and be to him a sure sign of salvation. It was found, and in 
a most unlikely place. Hannington's comment in his adiary is: 'A miracle! Jesus, by Thee alone can we obtain remission of our sins.' It is difficult to know what to make of this incident; was it an instance of mere superstition, or was there an element of true faith in it ? What if the ring had not been found? Hannington, writing several years afterwards, says that this strange occurrence befell him at the most worldly period of his existence.

Mr. Hannington, James' father, held the tenets of the Independents, and had built a chapel in the grounds of his residence, in which Nonconformist services were held. At the end of 1867 , however, the family joined the Church of England, and St. George's Chapel was licensed for public worship by the Bishop of Chichester. The Nonconformist minister and his wife were pensioned by $\mathrm{Mr}$. Hannington, the pension to continue for the survivor's life.

James now began to interest himself in religious matters, and his loathing for the business at Brighton led him to think about the ministry as a profession, although to-outward appearance he was still as gay, thoughtless, and reckless as ever. However, he kept Lent of 1868 with much severity, fasting twice a week. He told his mother that he had decided in favour of the Church and that he believed that God was with him in the matter. He went to all the special religious functions in the neighbour- 
hood, heard the distinguished preachers that exercised their ministry in, or visited, the vicinity, attended the Church services regularly, and altogether was what would be called a very active church worker. Religion was in his head and hands and feet, but not in his heart and soul. Nevertheless, it was decided that in due course James Hannington would seek ordination as a clergyman of the Church of England.

Accordingly, in the autumn of 1868 , Hannington entered St. Mary's Hall, Oxford. $\mathrm{He}$ was then twenty-one, a tall, handsome fellow, full of 'go' and fun. He was a thoroughly 'good fellow,' and from the beginning of his college course to the end he was the most popular man at St. Mary's Hall. He was not, however, a brilliant or successful student, he cared little for the classics, and his own favourite subjects, botany and natural science generally, were not the sort that brought high marks and distinction to a man whose end was the ministry. It was something, however, that he should even think of preparing himself for a profession, for he had private means more than ample to supply the wants of an irresponsible young bachelor.

Hannington kept open house at St. Mary's and had hosts of friends. His pranks made him something of a trial to the Principal of the Hall, but his good-nature was recognised and his offences against college discipline winked at. Upon one occasion, however, the Principal remonstrated with him 
upon want of attention to study, and inquired how long he intended to continue ' a gentleman at large.' Hannington rather 'cheekily' replied that he intended in future to be a gentleman at 'smalls.' 'Smalls' is, of course, the name of one of the examinations to be passed by the undergraduate in his progress towards his degree.

His studies, such as they were, did not seriously interfere with his sports, and especially with boating, of which he was passionately fond. Of course he was elected captain of the boat club. Hannington had, and continued to have throughout life, that indefinable something which we call 'weight' or ' character' which points out a man to his fellows as their born and natural leader; the impress of his personality, without any conscious effort of the man himself, made itself immediately felt wherever he was-whether in the committee-room of the C.M.S. at Salisbury Square, or amidst a throng of excited, squabbling, perverse natives in the heart of Africa.

Hannington spent the vacations in ceaseless travel on the Continent and elsewhere. When in the autumn of 1869 he returned to Oxford the Principal of St. Mary's, thinking that the situation was now serious, advised him to find a tutor in the country and read steadily for his degree. Accordingly we find Hannington in the household of the Rev. C. Scriven, Rector of Martinhoe, a wild lovely corner of the North Devon coast. 
Hannington fell in love with the place and the people. He was the sort of man whom everybody very soon got to know and like. He several times came near to losing his life in the course of his adventures among the rocks of the wild coast. We hear little about his studies, but in any case he passed his Responsions in the following June. He suggested to Mr. Scriven that he should come to him at once as his curate and read for his degree afterwards, but the Bishop refused to ordain him until he had graduated.

The death of his mother, whom he passionately loved, made a deep impression on the heart of Hannington. Her last words were from Holy Writ. She kept repeating, 'I will take the stony heart out of their flesh and will give them an heart of flesh. I will take-I will take the stony heart away-away.' As she breathed her last her heart-broken son fell on her face and kissed her and cried to her, as though she could still hear him.

'It was almost impossible,' Mr. Dawson writes, ' to bear him away from her bedside. He would sit there in the silent gloom, hour after hour, plunged in grief that refused to be comforted. Or he would be found kneeling by that figure so mysterious and still beneath its enveloping sheet. They had to coax and almost to compel him from the presence of the dead in order that he might take rest or meals.' This sad event occurred on February 26, 1872 . 
Hannington took his B.A. degree in 1873 . His University course had been prolonged by his disinclination to study, but towards the end of it he had really worked hard. He now returned to Martinhoe to prepare for the Bishop's examination. He left his study of the Prayer-Book for the last fortnight's reading, and he was exceedingly unwell on the day when he had to tackle the examinationpaper on that subject. The result was that he failed and was overwhelmed with shame and despair. He was conscious of his own remissness, but also felt that the Bishop (Dr. Temple) was hard in his manner towards him.

However, though he was possessed of a sufficient competency, and the temptations towards a life of exploration or scientific pursuit must have been great, he persevered. Examinations were a terror to Hannington; put him down in front of an examination-paper and the chances were that all his knowledge would fly away out of his head. The second time he got through, although the Bishop told him that he must remain a deacon for two years and come up for an intermediate examination. 'You've got fine legs, I see,' added his Lordship; ' mind that you run all about your parish.' The ordination ceremony deeply impressed the susceptible young man: 'Behind Bishop and officiating clergy, he saw One to whose awful majesty he had consecrated the service of his life.' 


\section{Chapter II}

\section{THE STORY OF HANNINGTON'S CONVERSION}

First Sermon-Unconventional Country Parson-Something lacking-Distress of Soul-The wonderful Power of Prayer -The Light breaks.

THE power of prayer is strikingly illustrated 1 by the circumstances which led up to Hannington's conscious acceptance of forgiveness at the hands of Christ, and his absolute surrender of his life and heart and soul to his Lord and Saviour. We shall tell the story as succinctly as possible.

Hannington preached his first sermon at Hurstpierpoint among his own people. His friends congratulated him, but the young clergyman was not satisfied with his performance, and tore up the manuscript.

Then he began his duties as curate of Trentishoe, the sister parish to Martinhoe. There was nothing conventional about this country parson, "clad in a pair of Bedford-cord knee-breeches of a yellow colour, continued below with yellow Sussex gaiters with brass buttons. Below these a short pair of 


\section{I4 STORY OF HANNING'TON'S CONVERSION}

nail boots, four inches across the soles, and weighing fully four pounds. My upper garment, an all-round short jerkin of black cloth, underneath which an ecclesiastical waistcoat, buttoning up at the side.' He went about the scattered hamlets, riding on his rough Exmoor pony, with a Prayer-Book in one pocket of his shooting-jacket and medicines in the other. He was welcomed, admired, beloved everywhere. He sat up long nights with the sick and dying; those who came to him in want did not go away empty. He preached against immorality and hard drinking.

But he knew there was something lacking; he had not experienced the power of the Gospel in his own heart, and he could not preach what he had not experienced.

And now comes the memorable story. About thirteen months before the time of which we are writing, the Rev. E. C. Dawson, a college chum of Hannington, settled as a curate in a country parish of Surrey, was converted. He knew himself redeemed and in union with the Father of spirits. $\mathrm{He}$ began to think about Hannington and to pray for him. It seemed that the Lord had specially laid upon him the burden of that other soul. No letter had passed between the two for nearly a couple of years; but Mr. Dawson, coming upon a pair of skates that belonged to Hannington, wrote to the latter about where he wanted these skates sent to. And so a correspondence was opened. 
Hannington mentioned that he was meditating ordination and expressed a doubt as to whether he was as fit as he ought to be. This gave Mr. Dawson his chance. He knew that Hannington had openly expressed his contempt for religious enthusiasm and for what he considered cant. Nevertheless, Mr. Dawson resolved to risk the loss of Hannington's friendship. Here we must use Mr. Dawson's own simple and sufficient narrative: 'With prayer for guidance he just wrote a simple, unvarnished account of his own spiritual experience; tried to explain how it had come to pass that he was not as formerly; spoke of the power of the love of Christ to transform the life of a man and draw out all its latent possibilities ; and finally urged him, as he loved his own soul, to make a definite surrender of himself to the Saviour of the world and join the society of His disciples.'

Thirteen months passed away. No reply came from Hannington. Mr. Dawson concluded that the letter had been treated with contempt, yet he kept on praying for Hannington, feeling perfectly convinced that the Lord had laid that burden upon him.

The fact was that Hannington had read the letter again and yet again, that it had lain on his table all the year, and that he simply could not get away from the impression that it had made upon him. Yet there was no peace in his mind. At last he wrote to Mr. Dawson, saying that he was 


\section{I6 STORY OF HANNINGTON'S CONVERSION}

in much distress of soul, and begging his friend to pay him a visit, even though it were a short one. Mr. Dawson could not get away from his work, but he wrote a helpful letter, invited Hannington to come to him, and enclosed a copy of Grace and Truth, a volume by Dr. Mackay of Hull.

Hannington was in despair, it seemed to him that his death-knell had been sounded. He wrote to Mr. Dawson that darkness, coldness, and barrenness had seized hold upon him, that he was being bound by the devil hand and foot. "I have no faith, I can lay hold of nothing,' he cried in his agony; ' I cannot believe that I can ever be saved; and I feel that I have no right to preach to others. I try to feel that God willeth not the death of the sinner, but no ; I can preach it, and feel it for other persons, not for myself. Will the sun ever break through the clouds so that I shall be able to say, "Jesus is mine and I am His"?"

Hannington began to read Grace and Truth, but detecting in the preface a mistake in scholarship, as he thought, he threw it away in disgust and annoyance. But he felt that when he met his friend he would have to tell him about the book, so a second time he tried to read it. This time the book fared no better; Hannington disliked it so much that he determined never to touch it again. Yet he took it with him on a visit to Hurst. Once more he took up 'the old thing' and read on until he came to the chapter entitled 'Do you feel 


\section{A NEW CREATURE}

your sins forgiven ?' Then his eyes were opened. He was in bed at the time. He sprang out of bed and leaped about the room, rejoicing and praising God that Jesus died for him. In a short while he emerged finally from the mists into the full sunlight of the Father's smile.

In the autumn of 1874 Hannington and $\mathrm{Mr}$. Dawson met in Surrey. The time of stress through which Hannington had passed had had its effect upon his health, but the joy of his soul nothing could impair. The friends had sweet converse together concerning how the Lord had dealt with their souls. Hannington went back to his charge among the moors of Devon, to tell the people in his own simple, powerful language what he knew, what great things the Lord had done for him. His long anxiety was over, he had found the hidden treasure for which he had made a prolonged and painful search, and his joy was now 'exceeding great.' ' He shook off the chains of darkness and bounded into the light.' 


\section{Chapter III}

\section{A FAITHFUL MINISTER OF THE WORD}

A Devonshire Moorland Parish - Return to his Native Place-

'Hannington's Saints '-The old Fuddlers-Marriage-A successful Ministry-A fighting Christian-His Thoughts turn to the Mission Field.

ATER his conversion Hannington, not without a severe struggle at first, adopted the plan of preaching in extempore language. $\mathrm{He}$ prepared for his pulpit work carefully, and he made copious notes for his discourses, but for the actual words he trusted to the inspiration of the moment. He soon developed considerable power as a preacher. His father, when he heard him for the first time in St. George's, was deeply moved.

The young convert threw himself enthusiastically into evangelistic work. The record of his life from this time, until he offered his services to the Church Missionary Society seven years later, consists in great part of home mission effort among his own people and evangelistic tours throughout the country. His experiences from the first were encouraging. At Parracombe, in Devonshire, he 
preached in connection with a parochial mission there from Rom. v. I: "Therefore being justified by faith, we have peace with God through our Lord Jesus Christ.' He spoke the thing he knew, and his discourse was made useful to inquiring, anxious souls.

In the meantime Hannington continued to work quietly in his Devonshire parish. He now eagerly grasped every reasonable opportunity of communicating the Word of Life to the people. He was always a ' handy ' man, was James Hannington, and he acquired quite a reputation among his simple friends for his knowledge of medicine. He was sent for in almost every case, and he never missed a suitable occasion of speaking to his patients about their souls. The people over whom Hannington had charge did not number more than three hundred, but great distances had to be traversed over moorland roads and bridle paths. In every corner of the large area Hannington and his harum-scarum Exmoor pony were familiar friends. The young minister was happy in his work, and he had the satisfaction of seeing fruit from his labours.

A proposal from his father that he should take definite charge of the Chapel of St. George, Hurstpierpoint, was, therefore, not at all viewed with any feeling of bounding joy. Hannington was quite aware of the peculiar difficulties attaching to work among the people who had known him 
from boyhood-and that a rather wild, 'larky,' tempestuous boyhood, too. The style of discourse that did good among the inhabitants of a Devonshire moorland parish might not prove acceptable or fruitful among people who lived within a few miles of a genteel and fastidious place like Brighton. Then he was as yet only a deacon; neither his own Bishop of Exeter nor the Bishop of Chichester might wish him to undertake a new charge until he had received priest's orders. In sum, he was very loth to leave Martinhoe.

It was, however, just because the proposed transference was so contrary to his own natural inclinations that Hannington considered himself bound to give earnest heed to the suggestion of it. 'He ever distrusted his own flesh,' says Mr. Dawson; ' and thought that, in doubtful cases, it was a good and safe rule to run counter to its special pleading.' All the difficulties were cleared away, and Hannington resolved to risk the fate that too often overtakes a prophet in his own country.

Before taking up work at Hurst, Hannington spent the best part of three months at Darley Abbey, a suburb of Derby, in order to learn how to work a well-ordered parish. The vicar was the Rev. J. Dawson, a powerful and attractive preacher, a devoted parish worker, a successful minister of the Word in every sense.

During Hannington's stay there a mission was held by the Rev. C. Melville Pym. Hannington 
took part in it, every day giving an address, assisting at the after-meetings, and visiting from house to house. On one occasion he seized hold of a notorious drunkard and would not let him go until he had made a definite promise to attend that evening's service. Hannington took the hearts of the people by storm. His general manner might be a trifle boisterous, but to the aged, the weak, the suffering, the lonely he was tenderness itself; his manner then became quiet and gentle, and there was a ring of true sympathy in his voice.

Hannington preached his introductory sermon in St. George's Chapel, Hurst, on November 7, 1875. Mr. Dawson has given a charming account of Hannington's work as a faithful country parson. All the children of the place knew him. He would stop them in the street, give them little homilies as to their duties to their parents and to each other, and, as application to his discourse, out would come some goodies or bull's-eyes from the capacious pocket of the old faded boating-coat. A godly manliness was one of the most striking traits of Hannington's character, and therefore we are not surprised to learn that he was particularly successful in his dealings with boys and men. He interested himself in the pursuits of the boysit was not a mere patronising but a natural and a real interest; he showed wonderful skill in weaning them away from evil pursuits and evil companions and drawing them towards things that were lovely 


\section{A FAITHFUL MINISTER OF THE WORD}

and of good report. 'Boys who showed a liking for curiosities or natural history were invited to his house and allowed to examine his own large and various collections, and his cabinets of classified specimens.' All the same, he had a genial and effective way of snubbing boys who were inclined to be priggish or conceited.

A certain lad fancied himself as a musician, and Hannington readily consented to allow the use of his own harmonium.

'But when shall I begin, sir ?' asked the boy.

'Oh, well,' said Hannington, looking at him with an amused smile, ' I shall be out on Thursday.'

'Hannington's Saints' was the nickname given to the lads and young men that he gathered into his Bible class and temperance association. Hannington was a teetotaller,-indeed, it is believed, the first teetotaller that there was in Hurst. Many a time from his pulpit did he denounce the vice of intemperance in language that no one could fail to understand. 'The old fuddlers' was how he used to dub the alehouse theologians and pothouse politicians. One Sunday he gave out the announcement: 'I intend to preach a temperance sermon next Sunday evening; I am aware that the subject is unpopular, but you know my own views about it. I shall, no doubt, speak pretty plain, so if any of you do not care to hear me, you had better stop away.' The church was crowded.

Hannington waged war to the knife against 
drink. During his first year only four pledges of total abstinence were taken, but as a result of his perseverance, in spite of the most determined opposition, the number of abstainers gradually increased. There were no fewer than seven publichouses in the village. Hannington never went about without a pledge-book. Those who signed were derided by the cry of, ' $H e$ 's joined the saints,' but this petty persecution merely roused the zealous pastor to greater effort. He was perfectly fearless. With the utmost good-humour he would say, 'Ah! you're another old fuddler; won't you come and write in my little book ?' He had a well-known sign which he used to make; holding up his left hand he would write with his fingers upon it. Everyone knew that it meant, ' Come and sign the pledge.'

He did not mind preaching on behalf of temperance in the Church of the Annunciation at Brighton, though it was a ritualistic place of worship. When he gave out as his text, 'Take a little wine' (I Tim.v. 23), a look of terror passed over the faces of many persons in the crowded congregation, but Hannington went on to show-to quote his own words-that his brother had a stronger claim upon him than his stomach !

The absence of men from the churches is still, alas! a too common and too just cause of lament. But. no one looking round Hannington's congregation at St. George's ever asked, 'Where are the men ?' Hismanliness was his most conspicuouscharacteristic. 
He was a man first and afterwards a parson. Hannington was a true chivalrous knight; he had ' a way with the ladies' when it was necessary to employ it, but he was in no sense 'a ladies' man,' he was not the kind of parson that young damsels gush over. Practically all his friends were men; his greatest strength lay in the management of men, and in the power and conviction with which he could address himself to their souls.

The one and only love of his life was the lady whom he married in 1877 , Miss Blanche HankinTurvin. Until he met this lady, Hannington had imagined himself a confirmed bachelor; he enjoyed his 'independence,' he was a 'handy' man, not needing the ministrations of women, he had his own little stock of peculiarities which might not easily fit into the character of another, and, above all, he was wedded to his work. It was indeed in the interests of his work that his thoughts turned towards matrimony. A clergyman without a wife, he felt, lay under various disadvantages; if he is popular and good-looking the young ladies of his church are apt to embarrass him by their marked solicitude for his comfort and happiness, and he may easily find himself in positions of awkwardness and difficulty.

Hannington accordingly asked Miss HankinTurvin to become his wife because she was a lady of sound, earnest character, well qualified to discharge the duties of her new position. The 
marriage turned out to be one of perfect happiness. Hannington's character was softened and mellowed by matrimony, and he found in his wife a true helpmeet, who entered with all her heart and soul into his views of the Gospel and into his many good works.

Hannington kept back nothing from his Lord. He was very fond of riding, but receiving an impression from Heaven that he must deny himself this pleasure, he sold his horse and turned the stable and coach-house into a mission-room. As incumbent of St. George's he had no stipend; his private fortune, which had been ample for his bachelor wants, became something of a tight fit when he married, and a small band of little children began to grow up around him. Yet he managed to give away a considerable part of his income, in sums of $£ 50$, $£ 40$, and smaller amounts. There was no ostentation in his liberality,- the world knew little of it, and that the most insignificant part.

As a preacher, Hannington was not perhaps entitled to be called ' great,' but he was certainly effective. He knew what he meant to say, and he could make other people know it too. No conventional tones or attitudes were his. His thought, earnestness, and passion gave him language; he did not bother about the rigid correctness of his grammar or the classical turn of his periodsall that was beneath him. Practice soon put him in possession of a concise, pithy style; he knew 


\section{A FAI'THFUL MINISTER OF THE WORD}

his Bible well, he had thought deeply, he had passed thrôngh the crucial religious experience, he led a life of service and communion with his Lord,-these qualifications made him not only a cultivated but also a powerful preacher. $\mathrm{He}$ was never either dull or vague. He was as far removed as possible from the temperament of the Irish clergyman who sought laboriously for a euphonious synonym to the 'vulgar' word potato. 'What truths were made plain to his own heart, these he sought the power of the Spirit of God to enable him to make plain to the congregation.'

The result was that his little chapel was filled to its utmost capacity, that many souls were brought out of darkness into light, and many others built up in their most holy faith. Hannington preached for conversions. He never forgot that a great part of an ordinary congregation consists of people who have not definitely accepted the salvation of Christ and surrendered their lives to Him as their Lord and Master. He sought for broken hearts, contrite spirits, and souls willing to be saved through faith in the Redeemer.

Mr. Dawson records several striking instances of Hannington's devotion as a shepherd of the flock. A boy was seized with the smallpox, no one would go near the house where he lay, and the lad was dying for want of milk. Hannington fetched the milk, and prayed with the boy and his mother. The people of the parish were dreadfully 
alarmed when they heard that Hannington had visited the smallpox case. The relieving officer forbade the clergyman to go to the house, but, though the officer of health added his warning, Hannington did not so understand his duty. A lady member of his flock wrote to him entreating him not even to speak to her husband in his carriage out of doors for three weeks. Thanks no doubt in large part to the devotion of the minister, the boy recovered. Hannington devotedly and tenderly loved the flock over which God had made him a pastor.

A certain married man in the parish ran away with another woman, leaving his lawful wife destitute. Hannington put the police on the track of the scoundrel, and he was soon safely lodged in prison. $\mathrm{He}$ understood, however, that his duty demanded something more than bringing a malefactor to justice, namely, bringing him to repentance. Accordingly he called upon the prisoner, and sought to show him his sin in its true light. But the heart of the man was hardened. Yet Hannington appeared in the man's behalf in court, and said all that was possible in his favour with regard to his past history. The culprit was sentenced to three months' hard labour. Hannington called upon him again, and received nothing but reproaches and bitter accusations for his pains. But the devoted clergyman would not loose his hold on the man,-this was a soul to be won for the Lord, 


\section{A FAITHFUL MINISTER OF THE WORD}

and, God willing, he must be won. Hannington continued to petition the throne of grace for this hard-hearted sinner. When the man stepped out at the prison gate Hannington was there. There was an affecting interview, lasting three hours, and at last the sinner was penitent. There was joy in the presence of the angels of God. The poor fellow, now utterly broken down, was helped by Hannington to sail away to another land, there to live the regenerated life. In due time he returned every penny of the money that Hannington had lent him.

It would be difficult to find among men a more striking illustration of the sanctified pertinacity that marks the good shepherd of souls; if he lose one of his sheep he goes after that which was lost until he find it.

The doings of the vigorous, unconventional young clergyman, the large audiences he commanded, the spiritual success with which his labours were blessed began to be noised abroad, and he was offered livings with larger and better known spheres of labour. But he refused preferment, his constant reply being, 'I dwell among mine own people.' There was no occasion or excuse for slackness in the work of 'fishing for men' even in a quiet country parish.

Hannington had the happiness of associating his youngest brother Joseph with him in this work. He set Joseph to work in connection with 
his meetings. 'My part,' said Joseph, 'was to waylay souls and catch them by guile, in order that they might be induced to remain to be dealt with personally, or to seek an interview with him in his own study. Thus a goodly number were brought to the Lord. He was particularly apt in dealing with souls, and was much used in removing their difficulties and pointing them to a simple acceptance of the Saviour.' He started a Mothers' Meeting (the first ever held in Hurst), a Women's Bible Class, a Men's Bible Class, a Saturday Night Prayer-Meeting for Men, and other organisations, all of which were honoured by the Lord with much fruit.

A year before his marriage, referred to above, Hannington passed his final examination for priest's orders at Chichester. He was highly complimented by all examiners, five in number, and told that he had come out at the top of the list. It is characteristic of Hannington that he found recreation the day after his ordination examination by nesting in the Bishop's garden and round the belfry tower for swift's eggs.

Hannington was invited to conduct missions in various parts of the country. His accounts of these in his letters to his wife and in his diary are very vivid. At Atwick, for example, he tells us that a man walked all round the neighbourhood literally compelling the people to come in. Hannington describes the fruit as 'small, yet very blessed. 


\section{A FAITHFUL MINISTER OF 'THE WORD}

God be praised for even one ! Oh, the value of one soul ! it is priceless.'

He refers several times to the small but sometimes exasperating difficulties of evangelistic work.

At the end of a meeting at Birmingham he asked those who were anxious about their souls to stay behind. Thereupon the organist immediately stood up and announced a choir practice!

On another occasion a huge, tipsy man, wedged into the middle of the crammed meeting, kept interrupting the preacher. 'Nevertheless,' wrote Hannington, 'the Lord gave me immense power, so that I held them together in spite of intense interruption. But the strain was so great that I afterwards burst into tears.'

One man professed to be in a difficulty because he had been told that God came from Teman; evidently he was labouring under a strange misinterpretation of Hab. iii. 3. Those who labour in spiritual things among the poor frequently get staggering glimpses into abyssmal depths of ignorance. A parishioner of Hannington once asked him whether God was alive before Jesus Christ, who Paul was, and who the Israelites were.

Hannington cried earnestly to be filled, more and more, with the Holy Ghost. The entry in his diary on New Year's Day, I879, is: 'I pray for more earnestness, more love, more diligence, greater regularity, and entire consecration to the service of the Lord.' 
$\mathrm{He}$ had sometimes difficulties in his evangelistic work with some brethren in the ministry. A mission was held at Hurstpierpoint, one sequel of which was that Hannington got what he called 'a tremendous rowing' from a neighbouring clergyman, the root of whose grievance was that one of his parishioners had been converted at the mission !

Hannington's congregations used to include people of many denominations. On one occasion it was known that among his hearers were two Unitarians, two Roman Catholics, Ritualists, Wesleyans, Calvinists, a Quaker, Congregationalists, and Plymouth Brethren.

His experience of a mission at Ballybrack, by the lakes of Killarney, leads Hannington to remark that the people appeared to be ready to hear of the sins of the Roman Catholics, but never dreamt that Protestants were sinners too !

Hannington, up to this time, had confined his spiritual work to his own parish and to the missions that he was invited to conduct in different parts of the country. He knew little about foreign missions, and this fascinating theme had not yet gripped his heart. However, on one occasion at a friend's house near Derby he met Miss Gell, the sister of Bishop Gell of Madras, and with her had some talk about the work in the regions beyond. Gradually his mind and heart opened to the work of the advance guard in the army of Christ. He 
was just the sort of man, a fighting, chivalrous, knightly Christian, every inch of him, to whom that work, once known, would powerfully appeal.

$\mathrm{He}$ carefully notes in his diary the occasion of his first C.M.S. sermon. Towards the end of I88I he attended a meeting at Eastbourne, at which Mr. Eugene Stock, the editorial secretary of the C.M.S., gave an address. "If he had asked me to go out,' wrote Hannington in his diary, 'I should have said, Yes.'

It was the violent death of Lieutenant Shergold Smith and Mr. T. O'Neill on the shore of Victoria Nyanza, towards the end of 1877 , that first turned the thoughts of Hannington towards the heroic and devoted life of a missionary. Although his name is inseparably associated with Uganda, Hannington, oddly enough, never entered the country for which he laid down his life. For the sake of clearness we shall devote our next chapter to a brief statement of the Uganda Mission up to the point at which Hannington enters its history. 


\section{Chapter IV}

\section{THE EARLY HISTORY OF THE UGANDA MISSION ${ }^{1}$}

The first Missionaries in East Africa-Stanley's Letter to the Daily Telegraph-How it reached its DestinationAction by the C.M.S.-First Expedition to Uganda-Arrival at the Capital-Murder of Shergold Smith and O'NeillAlexander Mackay-General Gordon helps forward a C.M.S. Party to Uganda-Romanist Priests arrive and cause Trouble-The first Baptisms.

T UST over sixty years ago two German missionaries, labouring under the auspices of the Church Missionary Society, took up their abode at Rabai, on a hill near one of the many creeks which run inland from Mombasa, a chief seaport on the East Coast of Africa. These were Ludwig Krapf and John Rebmann. In the cause of the Gospel they made many journeys into the interior, discovering the snow-clad mountains of Kilimanjaro and suggesting the great lake system of Central Africa. They had heard from Arab

1 This chapter is a summary of the narratives contained in The Wonderful Story of Uganda, by the Rev. J. D. Mullins, M.A., and The History of the Church Missionary Society, in three vols., by Eugene Stock. Both works are published by the C.M.S. 
34 EARLY HISTORY OF UGANDA MISSION

traders tales of a great lake which had no end, 'although one should travel for a hundred days to see the end.' Stay-at-home geographers demonstrated by argument that no great lakes could exist along the line of the Equator, but Speke, Burke, and Grant went out to see, and proved that the missionaries were right.

Among the marvels reported by these travellers was the existence of a considerable kingdom on the more distant shore of the Victoria Nyanza, 700 miles from the coast. Here was a young king whose power was felt over thousands of square miles, and who, amidst much oppression and cruelty, had developed something like organised government. This was Mtesa and Uganda.

Then on November 15, 1875, appeared the famous letter of Stanley in the Daily Telegraph, in effect a challenge and an appeal to the Christian churches to send missionaries to Uganda. Nowhere in all the pagan world, he said, was there a more promising field than Uganda. The Baganda are a Bantu race, of intelligence and general capacity far beyond any other inhabitants of Central Africa.

The hand of God may be clearly discovered in the extraordinary adventures of this letter in its journey from the heart of Africa to Fleet Street. The only practicable route at that time (says Uganda Notes) was by the Nile. A young Belgian, named Linants de Bellefonds, was then in Uganda, and to him Stanley entrusted the letter. On his 
way north his expedition was attacked by the Bari tribe and he himself murdered. Some time later a punitive expedition, sent to inquire into his death, discovered the body still clad in the high knee-boots he was wearing at the time of his death, and in the boots, thrust in at the last moment, was Stanley's letter to the Daily Telegraph. It was forwarded to General Gordon at Khartoum, and by him sent to England.

Three days after the appearance of the letter 'An Unprofitable Servant ' placed $£ 5000$ at the disposal of the C.M.S. for the immediate and energetic organisation of a mission to the Victoria Nyanza. The Committee closed with the offer; another gift of $£ 5000$ was forthcoming, and in all $£ 24,000$ was soon subscribed. It must be remembered that the adventure was a much more daring and more perilous one than it would be nowadays. The temper of the chiefs whose territory must be traversed was unknown; communications were uncertain, and the climate was unhealthy.

The first expedition to Uganda was composed of George Shergold Smith, an ex-Lieutenant of the Royal Navy, who was studying for the ministry of the Church of England; Alexander Mackay, a young Scotch engineer; the Rev. C. T. Wilson, a Manchester curate; Mr. T. O'Neill, an architect; Dr. John Smith, a qualified medical man from Edinburgh; G. J. Clark, an engineer; W. M. Robertson, an artisan; and James Robertson, a builder from 
Newcastle, - in all eight persons. The last-mentioned had been rejected by the doctors and accompanied the pioneers at his own risk and expense.

By the end of April 1876 all had sailed for Africa. James Robertson, fulfilling the warning of the doctors, died on the coast before the journey into the interior was begun. The track followed was an old trade round, beginning on the mainland opposite Zanzibar, proceeding about 250 miles west, then about 300 miles in a north-westerly direction to the south of the Victoria Nyanza, whence Uganda was to be reached by a long voyage in canoes, skirting the shores of the mighty lake.

Mr. Mullins draws a vivid picture of the acute discomforts and dangers of the journey. First there is the heat, like that of a furnace, yet damp, causing exhaustion and depression. Then there is a continuous plague of insects, centipedes, snakes, and beasts of prey; thirst; fever; menacing demands from all the petty chiefs for tribute. All the materiel of the expedition, including the food, and the cloth which served for money, had to be carried on the heads of the black porters. 'The long, straggling line which wound its way along the narrow paths often comprised hundreds of men; some deserting, some falling ill and dying, some attacked by robbers.' The journey to the lake occupied six and a half months, the shore of the Victoria Nyanza being reached on January 29, I877. 
The expedition, as we have said, started with eight white men. One was already dead. Mackay was prostrated with fever when the expedition had reached Mpwapwa, 220 miles inland, and was ordered back to the coast. Clark was placed in charge of the station at Mpwapwa, but was afterwards forced by ill-health to return home. W. Robertson was invalided home shortly after the party had started onwards from Mpwapwa. Four members of the party reached the southern shore of the lake, having had to fight their way through waterless deserts and malarial swamps. Dr. John Smith died there. O'Neill was left behind.

Meanwhile news of the arrival of the missionaries on the southern shore of the Lake had reached Uganda, and Mtesa had sent letters urging them to come quickly. These letters were written in English by a lad who had been brought up in Bishop Steere's mission-school at Zanzibar, had travelled into the interior with Stanley and been left by him in Uganda.

Shergold Smith and Wilson pressed forward in the 'Daisy,' a small steam-launch which they had brought with them in sections. Trying to land at an unknown place they were assailed by a shower of stones and arrows. Smith was rendered almost blind by injuries from the stones, and Wilson's arm was pierced with an arrow. No further mishap was encountered, and Rubaga, the capital of Uganda, was reached on June 26,1877 , a date ever to be 
remembered in the annals of mission work. . Shergold Smith and Wilson were escorted to the reed-walled palace of the king through lines of soldiers dressed in white raiment. Salutes were fired in honour of the missionaries and of the name of Jesus.

After the ceremonial reception, says Mr. Wilson, ' the king sent a message to say that he had one word which he wanted to say to us, but was afraid to do so before the people in the morning. So about four o'clock we went up. . . He said he wanted to know if we had brought the book-the Bible.' Of course they had.

Soon a mission-house was built by order of the king. Shergold Smith returned to the south of the lake to join O'Neill, and to bring up the rest of the stores. A sudden quarrel broke out in that region between a native king and an Arab trader from whom the missionaries had purchased a dhow. The Arab fled to the missionaries for shelter. The king demanded his surrender. The missionaries refused, their camp was attacked, Shergold Smith and O'Neill were slain. This disaster happened on December 7, I877. It was the news of it which first led the thoughts of Hannington towards the mission field.

Wilson was now alone in Uganda, and remained so for nearly a year. In the meantime Mackay had started again from the coast; this time he reached his journey's end, arriving at the lake about the middle of June and at Uganda in November I878. 
The C.M.S had in the meantime determined to send a new party to Uganda by the Nile route. Gordon, who was then Governor-General of the Soudan, had offered to assist any men who might be sent that way. Four men were selected by the C.M.S. : Pearson, who had been an officer in the P. \& O. service; Felkin, a young doctor; Litchfield and Hall, students of the C.M.S. College at Islington. They left England in May 1878. Hall, however, was disabled by a sunstroke in the Red Sea and had to return. The other three went on camels across the desert from Suakin to Berber, and thence up the Nile to Khartoum, where they were received with unbounded kindness by Gordon. He sent the party on by his steamers, and at his personal expense, right up to the frontier of Uganda. Pearson, Felkin, and Litchfield thus joined Wilson and Mackay early in February 1879.

Soon after two French Roman Catholic priests reached the country, and at once began to act in opposition to the English missionaries. They not only refused to join in the worship which Mackay conducted at the king's court, but denounced him to the king. Mtesa was sorely perplexed. 'Has every nation of white men another religion ?' he asked. The French priests had brought for Mtesa just the kind of present he most valued-rifies, powder and shot, military uniforms, helmets, and swords.

Two more C.M.S. men arrived in April, Stokes 
and Copplestone, making now seven Protestant missionaries in Uganda. Soon, however, four of them-Stokes, Copplestone, Wilson, and Felkinleft the country, their services being required in other spheres of labour. The king's caprice, the slander of the Arabs, and the opposition of the French priests combined to cause much discomfort to Mackay, Litchfield, and Pearson. Litchfield left in June I880 and Pearson in March I88I.

Nevertheless the period was, upon the whole, one of much practical work-teaching, preaching, translating, and introducing the elements of civilisation. Mackay was not left alone. He was joined in March I88I by the Rev. Philip O'Flaherty, who proved himself to possess a remarkable personality, with a singular power of picking up a language, and great readiness in making the best of untoward circumstances.

The mission had already begun to gather fruit. In the previous year two lads had openly avowed their belief in the religion of Christ, and were in consequence seized, bound, and sent away into the country. A third youth came to Mackay, on October 8, I88I, with a note written by himself with a pointed piece of spear-grass, and asking fol baptism because he believed the words of Jesus Christ. A fourth lad, when dying, had induced a companion to fetch some water and pour it on his head, saying over him the names of the Father, the Son, and the Holy Ghost. The companion, after the lad's 
death, came to the mission and told the story, bringing his dear friend's Gospel of St. Mark-a tentative version printed by Mackay-which he said had been constantly read by him.

The French priests had already baptized half a dozen lads. The ' gospel ' of fear which they preached proved more quickly effective than the Gospel of Grace. 'How many more days ?' said one who had been instructed for two months, and was told to wait a little; 'see, I tremble in every limb when I lie down to sleep at night in the thought that death may surprise me and cast my soul into eternal fire.' This was in I88o. Not till March I882 did the first Protestant baptism take place; but on the I8th of that month, to the great joy of the two missionaries, five well-tested converts were publicly admitted to the Church. Only a few days later a fifth, who had found the Saviour in Uganda, was baptized 800 miles away.

And this brings us to the date, May I882, when Hannington set out from England as the leader of a new expedition to Uganda. ${ }^{1}$

1 This is a convenient place to note that in the language of the country itself the place is Buganda, the people Baganda, a single native Muganda, and the language Luganda. 


\section{Chapter V}

\section{AN ADVENTUROUS JOURNEY: HANNINGTON'S NARRATIVE}

Hannington offers himself to the C.M.S.-Made Leader of a new Expedition to Uganda-Touching Scenes at his Farewell Sermon-His own vivid Narrative of his Adventures.

T THEN Hannington first definitely thought of offering himself to the C.M.S. he was held back by the fear in his secret heart that he might not be accepted, that he was not worthy of the honour. He did not perceive what was evident to those who knew him, that no man was more fitted by natural gifts and temperament and the grace of God for work of toil and danger, in the interests of the Gospel, among a savage race. $\mathrm{He}$ was tall, strong, fearless, fond of travel and adventure ; he had the habit and the gift of command, and great influence over men, especially over rude and untrained natures. He was clearly marked out by God for the work to which he felt his heart was being drawn.

Although some of his friends produced an abundance of specious arguments in favour of his staying at home, the upshot of the matter was that 
Hannington placed his services at the disposal of the C.M.S. for work in Uganda. For payment he asked nothing more than his travelling expenses, of which he undertook to contribute $f$ loo a year himself and $£ 50$ towards his outfit. The C.M.S. undertook during his absence to 'supply' St. George's Chapel with retired missionaries or missionaries at home on prolonged leave. These proposals were accepted. When Hannington announced his decision to his congregation, many of the people wept aloud. They were not rich, but they subscribed $£ 85$ towards the initial expenses of this great Gospel adventure.

Hannington was placed in command of the new expedition to Uganda, which consisted of six menhimself, the Rev. R. P. Ashe, B.A., St. John's College, Cambridge, J. Blackburn, Cyril Gordon (Hannington's nephew), W. J. Edmonds (three students of the C.M.S. College), and C. Wise, an artisan. The route was to be the same as that taken by the first C.M.S. party to Uganda, due west from Zanzibar for over 200 miles, then northwest to the southern shore of the Victoria Nyanza. Uganda, which is on the north-west of this mighty inland sheet of water-20,000 squares miles, with an island in it as large as the Isle of Wight-was to be reached by canoes, skirting the shores.

A book about Uganda, written by Wilson and Felkin, ${ }^{1}$ had just been published, and very favourably

${ }^{2}$ See previous chapter. 
reviewed in the Times. Hannington took advantage of the public interest in the country to make an appeal in that paper for a new boat with which to navigate the Victoria Nyanza in place of the 'Daisy,' which had been wrecked. The response was adequate, and that in itself was an encouraging beginning.

His farewell sermon at Hurst sent a thrill of emotion through the densely-crowded audience. He said that if he lost his life in Africa, no man was to think that his life had been wasted. As for the lives which had been already given for the cause, they were not lost, but were filling up the trench so that others might the more easily pass over to take the fort in the name of the Lord. A great crowd waited for him outside the church, forming a continuous double line all the way to his own house. He had a formidable ordeal of handshaking to go through.

On the morning of his departure his boy-servant, Tom Lowry, flung his arms round his neck and mplored Hannington not to leave him. Another friend, who had been breaking his heart for a month about Hannington's departure, offered to work his passage to Zanzibar if he might be permitted to follow him. The three little children could not, of course, comprehend all that it meant, but they cried, 'Come back soon, papa!' The parting from his wife need not be described. As he was about to jump into his brother's carriage, 
a publican's son crept up and thrust a letter into his hand, a pretty book-marker and a text, and a letter written by his mother.

Hannington started on this great missionary journey, one of the most thrilling and perilous ever undertaken, from the Thames on May I7, I882. At Aden the party for Zanzibar, opposite to which the expedition into the interior was to begin, were transported into a filthy old vessel called the 'Mecca,' dreadfully overcrowded, and swarming with cockroaches, black ants, and bugs. Food, accommodation, and management were as bad as bad could be. The voyage was stormy, a feeling of discomfort developed into one of horror, and Hannington, old sailor as he was, was prostrated with sickness. It was with great relief that the island of Zanzibar was sighted on June I9. We are now happy to be able to take up the narrative, for a considerable number of pages, in Hannington's own words :-

'You will be glad to hear that I have completed the voyage through the Red Sea most satisfactorily, and have duly arrived at Zanzibar. The journey out I shall not attempt to describe, since there was nothing very extraordinary about it, nor must we delay for any length of time discoursing upon Zanzibar, for it is well-trodden ground, and we have far wilder scenes before us. The streets, like those of all Oriental towns, are very narrow and 
tortuous, and have such a cut-throat appearance that at first one seemed afraid to venture far, but experience soon showed that there was nothing to harm beyond that occasional fragrance which one is wont to come across in every foreign town.

'As we peep into the shops we perceive that for the most part the traders are not negroes, but Hindus, and that they are subjects not of the Sultan of Zanzibar, but of her Majesty the Empress of India. Their wares are not very inviting, being chiefly cheap Manchester and Birmingham goods. Even the strange-looking cakes and sweetmeats that are occasionally to be seen would scarce tempt Miss Hettie to delay, although I expect I should have had a different tale to have told had she been there.

'When we got a little farther on we reached the African quarter, and saw piles of bananas, oranges, mangoes, and other kinds of fruit strewing the ground. We glance through a half-open door, and notice some camels solemnly turning a mill. They are extracting the oil from ground nuts, which will probably be sold for the best Sorrento olive oil.

'Outside the town a delightful scene meets the eye. Dark-spreading mango, vine, lemon, orange, broad-leaved bananas, and plumed cocoanut trees are crowded together with the luxuriance of a forest, while pineapples are planted along the roadsides, or are massed together in small enclosed gardens. Here and there groups of tropical vegeta- 
tion crown a gentle slope ; or, standing out against the clear sky, form a succession of beautiful pictures which I hope would have more attraction for you than the mandarin oranges hanging overhead.

'How you would have laughed to have beheld your sober old ${ }^{1}$ uncle climbing a cocoanut treeone, by the bye, that was somewhat out of the perpendicular-and you would have been still more amused to have seen his energetic struggles to emancipate the nut from its fibrous husk. But I must leave you to digest that cocoanut whilst I visit his Majesty the Sultan, Bargash Bin Said, the noble and energetic ruler of Zanzibar.

'People in our station of life do not visit Sultans every day, so I will endeavour to give you a full description of the interview. The palace is well situated in the Grand Square, and looks out on the roadstead, beautiful with its deep blue water and varied flotilla. Thither, at the appointed time, Colonel Miles, Acting Consul during the absence of Sir John Kirk, conducted me, duly arrayed in cap and gown, together with Captain Hore, of the London Missionary Society, who was also to be presented. A guard of honour was drawn up in front of the palace, and saluted upon our arrival.

'The Sultan then appeared on the scene, shook hands cordially, and beckoned us to follow him. We mounted some stairs, which were so steep that

${ }^{1}$ This is merely Hannington's fun. He was only thlrty-four at the time. 
they formed a perfect safeguard against an inebriate thrusting himself into the royal presence, and then were led into a small reception room, and bade be seated on elaborate amber-satin arm-chairs. Immediately attendant slaves brought coffee, in glass cups, tastefully mounted in gold. That was coffee ! I should like to soliloquise on it, but you are not old enough to appreciate delicate flavours. You would have done greater justice to the iced sherbet which followed; only, if I mistake not, you would have looked rather glum when, having taken a gentle sip (it is vulgar to take deep draughts in the presence of kings), the attendant at once presented a tray, and relieved you of your burden.

'Conversation now waxed warm. The Sultan was greatly interested in our movements, asked me many questions, through an interpreter, as to how we travelled, how long we expected the journey to take; and he was further very inquisitive about a report that he heard of a serpent in Ugogo, reputed to eat up whole oxen and women and children !

' The royal attire was the plain everyday costume of wealthy Arabs-the long black coat, trimmed with silver, an ordinary turban, a handsome waistband, in which were thrust two finely-wrought dirks, while a very handsome ring, worn German fashion on the first finger, graced his hand. His Majesty was exceedingly courteous, and did his utmost to entertain his guests. Upon our rising he also rose, 
led the way into the Grand Square, and wished us farewell.

'I must now hastily pack my goods in small bundles of about half a hundredweight, hire porters, and cross to the mainland. I should perhaps explain to you that on account of the ravages of the tsetse fly we are unable to use beasts of burden, and so are compelled to have all goods carried by porters. These porters are for the most part of two different races-namely, the Wanguana, or coast men from Zanzibar, and the Wanyamwezi, or the men from the Country of the Moon, that vast region which lies to the south of the Victoria Nyanza.

'Our next step is to hire an Arab dhow, which is to take us over from the island of Zanzibar to the little town of Sedaani. We pack in as tightly as safety will allow, weigh anchor, and soon after reach the coral-bound coast.

'We touch bottom about half a mile from the beach, and, as there is a heavy ground-swell on at the time, the crazy old dhow threatens to go to pieces. So while some made their way to shore in a small dug-out canoe, half full of water, your uncle put his clothing in a bag, plunged into the water, unmindful of sharks, and thus, with a heart throbbing with emotion-and, I might add, feet throbbing too, for the coral was sharp-entered the land of Moffat, Krapf, Livingstone, and Gordon. That I was not prudent thus to fling myself into the water I will allow, but you cannot fully enter into the 
feelings aroused by such tremendous associations in the heart of one whose life was about to be devoted to Africa.

'It is not too much to say that the poetry of the situation was dispelled shortly after by our sitting down to dine on a tough goat. I have seen goats on the table which knives refused to manipulate, and chickens whose limbs denied that they would part company, so strongly were they attached to each other, until one seized hold of one leg and another the other, and had a tug-of-war.

'It will not do to expatiate on the comforts and discomforts of tent life at this early stage of the journey. I believe that most of us slept well ; nor did I hear of more than one bed coming down with a crash. But no doubt I shall have some pleasant little adventures of this kind to talk about hereafter, but we will not anticipate evil, nor meet troubles half-way. One more day being required to set things in order and to call over the loads, we remained where we were, and did our utmost to get our baggage thoroughly shipshape, and on the morrow, June 30,1882 , we started for the interior,-seven white men and about five hundred porters, headmen, and tent-boys, all told.

' It may assist your geography if I give you a brief description of the whole route from the coast to the lake.

' It has been well divided by the great African traveller Burton into five different regions. The 
first of these is the coast belt which lies between the Indian Ocean and that vast chain of mountains which runs from Abyssinia to Lake Nyassa, and numbers among its peaks Kenia and Kilimanjaro. This district abounds in rivers, and has the general appearance of English park scenery. The second region is that occupied by the mountain chain we have just named, and is truly beautiful, being in places not unlike the best parts of North Devon. Here we have two flourishing mission stations, namely, Mamboia and Mpwapwa.

'Leaving this truly delightful district the third region is entered, which comprises the thicklypopulated plains of savage Ugogo, and two or three almost uninhabited and waterless tracts. Fourthly, you come to the country of the Wanyamwezi, or People of the Moon, the great traders, and consequently travellers, of Equatorial Africa ; here we have one station, Uyui. Then, lastly, the great lake basin is reached, which nurses in its bosom the mighty Victoria Nyanza. Each of these regions is well defined, the people and the physical features being very different; but more of this as we proceed.

' Our first experience, I think, might well have disappointed those in search of wild adventure, or what you in England picture to yourselves as tropical scenery. It is true that from the moment we left the coast candle-shaped euphorbias, umbrellalike acacias, and long-spined mimosas were at once 
met with; - but no very wonderful butterflies or birds or flowers dazed the eye with their brightness, much less did savage beasts break from the thicket, or disturb our slumbers by their nocturnal roarings.

'If you want to learn a little about the hardships of the missionary's life, you must think of him as compelled to march day after day under the rays of a tropical sun. Night-marching, which many suggest, is quite out of the question. The roads are too narrow and rough; the men, with their bare feet, tread on the thorns and stones, and get maimed; nor can one see them if they linger behind, or even desert us altogether. Once or twice we were compelled to march through the night in order to reach water, and we found it more trying and dangerous than even tramping at midday. On one of these occasions, after arriving at camp, and calling over our men, we found that one was missing. A search-party was sent back, and presently they spied a pool of blood in the footpath, which told the dismal tale that he had straggled from us, and been set upon by robbers, who had speared him to death, dragged his body into the jungle, and had stolen the valuable load that he was carrying.

Another great cause of suffering was the frequent absence of water, or, when not absent altogether, it was often so thick and black that it is scarce an exaggeration to say that one looked at it and wondered whether it came under the category of 
meat or drink. At times it was lively, so much so, that if you did not watch the movements of your "boy" with fatherly anxiety, you always stood a chance of an odd tadpole or two finding their way into the tea-kettle; occasionally it showed a bright green tinge. I had previously seen green tea, and had been taught studiously to avoid it; but green coffee was a new and at times unavoidable delicacy only known among the luxuries of African travel. But I cannot say that I minded very much about finding the pools lively with toads, or even crocodiles, and I soon grew tired of grumbling because dogs and men would bathe in our drinking-water; but I did not like to find dead toads and other animal and vegetable putrefaction. Afterwards, when weak and ill, I used to avoid drinking any liquid; I have been three and even four days at a stretch without drinking anything at all. But while we are talking about water I must tell you about my river experience.

' On the 8 th of July I882 we reached our first stream. Loud had been the warnings that we should not wade through or bathe while on the march, lest we should catch fever, for it was here that one man nearly died because of his imprudence. I was exceedingly hot when I arrived at its banks, and needed no advice. Well, just at that moment there were no headmen up, and I was going to wait patiently, when my boys volunteered to carry 
me across, a feat they could very well have accomplished. But the ambitious Johar must needs have all the honour and glory to himself; he seized me and bore me off in triumph. I felt an ominous totter, and yelled to him to return. But I shouted in vain; he refused to heed. More tottering, more entreaty to go back; but all to no purpose; on he pressed. Swaying to and fro like a bulrush in a gale of wind, I clenched my teeth and held my breath. They shout from the bank for Johar to retrace his steps, but it has not the slightest effect; he feels his only chance is to dash right on. Midstream is now gained, and my hopes revive; I think, perhaps-but the water deepens, the rocks become more slippery, a huge struggle, and down we go flat, Johar collapsing like an india-rubber ball punctured by a pin. Far better to have walked through with all my clothes on, for I should then only have got wet to the knees; but now no part of me could claim to be dry. Luckily, however, I did not get an attack of fever, as I expected.

' Not long after this adventure we came to a broad and deep arm of the Wami. Here the vegetation underwent a complete transformation, assuming an entirely different aspect, and we beheld for the first time what is usually understood by the term "tropical forest scenery." Gigantic trees, towering aloft, and supporting endless creepers and parasitic plants, presented to the eye 
every shade and variety of foliage. There a mass of jasmine filled the air with its perfume; there a euphorbia, like the candelabra of the Jewish temple, stood stiffly erect; and from the boughs of those trees which overhung the stream the great belted kingfisher watched for his finny prey.

- The natives possessed a small dug-out canoe, which tempted me to go for a paddle midst the fairy-like scene; but the evil spirits of the vasty deep below, in the shape of crocodiles, soon forced me to beat a hasty retreat, and make for the less enchanted ground of the camp. It was probably this same stream that we crossed, after about three days' march, by a curious native bridge of poles, and trees, and living creepers pitched and tangled together in a most marvellous manner. Living poles one has often seen used. I remember four trees being topped, and the roof of a shed put on them, and the shed gradually getting taller and taller; but this was the first time I had seen living ropes binding a bridge together, and stretching across to form a handrail for the wayfarer. It was intensely picturesque, but equally inconvenient, and took the men with their loads about two hours to cross. There was not that general activity amongst them that I expected; some almost wanted to be carried over as well as their loads, though others bounded across like monkeys. While at the riverside I heard a sharp but familiar note, and looking up I beheld our gay old friend 
the English kingfisher, in his bright blue uniform, by far the most handsome bird I had yet seen in Africa. Only one load was dropped over the cobweb-like parapet of the bridge, but that of course was a box of cartridges, being one of the most spoilable things they could find; it, however, was better than a man being snapped up by a crocodile.

'Within a mile of this we had to cross the stream again. Here the river had considerably widened, and was spanned by a gigantic fallen tree, of enormous girth and length; it must have been about I5o feet long. On arriving at the village we found that a false report that we were exceedingly hostile had reached the natives. Accordingly they had fled pell-mell, leaving behind them nothing but empty huts. In cases of this kind it is extremely difficult to restrain the men from plundering the sugar plantations and banana trees, for they must have something to eat. Then, if they steal, the natives naturally say the report was right, and the white men are robbers.

'This district was very swampy, and here, I think, we began to get incipient fever. It was a memorable sight to see the swamps at night literally blazing with fireflies darting about like millions of miniature meteors; here, too, we met with another accompaniment of marshes, which did not amuse us in the least-namely, mosquitoes, in equal myriads. 
- As we journeyed on more rivers had to be crossed. At one I had an amusing adventure with our hospital donkey, which we kept for the transport of invalids. It happened to be at hand at the time I wanted to cross, so, having had an experience of a two-legged donkey, I thought I would try the four-legged one. The wretch had on neither saddle nor bridle at the time, but was very quiet and docile until we were well into the stream, when suddenly he became tired of his burden, and began to play the natural pranks characteristic of that worthy race; his hinder part became slightly elevated, his head bobbed, and he threatened to lie down and roll. The headmen, however, saw my predicament, and rushed at me, caught me up as if I were a wisp of straw, and bore me in a horizontal position over the donkey's head to the farther side.

- At the next stream I selected two men, and was assured it was exceedingly narrow, and so it was; but there was no exit on the other side, an impenetrable fringe of reeds and jungle hedging us in; so we turned up stream. I had to urge and urge and urge them not to drop me until we gained a small sandbank a little ahead, where I stripped and waded the best part of a mile before we found a break in the dense tangle.

' July 2ist we reached our first mission station, Mamboia, about 150 miles from the coast. Here our good missionary and his wife, Mr. and Mrs. 
Last, met and welcomed us, and instantly carried me off to their comfortable quarters.

'The house, or perhaps the word bungalow describes it better, is prettily situated on the mountain side, about 3000 feet above sea-level, and commands most extensive and beautiful views. Immediately on the left side rises a precipitous cliff, in which a grand old eagle has its eyrie; to the east the mountains form an amphitheatre, and bold jutting crags add wildness to the scene; all that it lacks to make it surpassingly beautiful is water.

' The soil is most productive, and the climate sub-Alpine, so that our English vegetables grow to great perfection. The flower garden in front of the house was one mass of geraniums, nasturtiums, petunias, and other denizens of our home gardens. We had not had enough of the wild flowers of Africa to care much for these. Next the house was the church, a very original structure. Circular mud walls had been built to the height of about six feet, which were covered by a deep sloping roof open in the centre, from which rose wooden stanchions, which in their turn supported a cap roof; thus open space was left between the two roofs for ventilation. The luxury of pews was not needed, the natives preferring to sit on the ground, and two chairs served for the ordinary European portion of the congregation.

- The Sunday we were there of course was an 
exception. On this occasion the church was quite full. Parts of our prayers were read in the Kiswahili tongue, as well as the Lessons for the day. Two or three hymns were sung; and by giving them out a verse at a time the natives were able to join. Then followed the sermon, which always takes the form of catechising, or is even more conversational still. Although, in these early days, no definite results in the way of conversions are known of, yet it is most encouraging to see the natives listening attentively and sending their children to be educated.

' On 25th July we were fain to proceed, our friends accompanying us as far as they could; but at length a river decided the question, and with many heart-achings we said farewell. With one, Mrs. Last, we were to meet no more on this side of the narrow stream of death. The march was a long one. We crossed a lovely looking rivulet, clear as crystal; but its waters had a strong taste of Epsom salts, and the effect produced by drinking them was much the same. There are many saline springs and streams to be met with in Africa. Woe betide those who are unwary enough to partake of them! When the wave of civilisation spreads over the land these places will be the Baths and Buxtons of East African society.

- This part of the country abounds with game. On one occasion a herd of antelopes crossed the path as tamely as if they had been sheep, and 
tracks of giraffe and larger game were frequently seen. Guinea-fowl were so plentiful that one of the white men at Mpwapwa told us that he did not trouble to fire at them unless he could ensure killing two or three at a shot.

'I had two narrow escapes in one of my walks with a gun in search of game. I came to a belt of jungle so dense that the only way to get through it was to creep on all-fours along the tracks made by hyænas and smaller game ; and as I was crawling along I saw close in front of me a deadly puffadder ; in another second I should have been on it.

' The same day, on my return, I espied in one of these same tracks a peculiar arrangement of grass, which I at once recognised to be over a pitfall; but though I had seen it I had already gone too far, and fell with a tremendous crash, my double-barrel gun full-cocked in my hand. I had the presence of mind to let myself go and look out only for my gun, which fortunately did not explode. On arriving at the bottom I called out to my terrified boy, Mikuke Hapana, "There are no spears," a most merciful providence; for they often stake these pitfalls in order to ensure the death of the animals that fall into them. The pitfall could not have been less than ten feet deep, for when I proceeded to extricate myself I found that I could not reach the top with my uplifted hands.

' Undaunted by my adventures, and urged on by 
the monotony of nothing but tough goat on the sideboard, I started before the break of next morning in pursuit of game, and was soon to be seen crawling on hands and knees after antelope, I am afraid unmindful of puff-adders and pitfalls.

- By and by the path followed the bed of a narrow stream, which was completely ploughed with the tracks of buffalo and giraffe, as fresh as fresh could be. Our impression was, and probably it was right, that the former were lurking in the dense thicket close by. The breathless excitement that such a position keeps you in does much to help along the weary miles of the march, and to ward off attacks of fever. All experienced hands out here recommend that men should, while not losing sight of their one grand object, keep themselves amused.

- Your cousin Gordon and I, with our boys, had led the van all the morning. $\mathrm{He}$, having lately had fever, complained of being tired, and begged me to continue in pursuit of game alone, merely taking my one faithful boy with me to carry my gun; but I refused to leave him, for never had I complained of an ache or pain but what he was at my side to help and comfort me. We sat down and rested, and the other brethren, with a party of a dozen or fourteen, marched on ahead. They had not gone many hundred yards before I heard the whiz of a bullet. "They have found game," said I. Bang went a second shot. "It's a herd." Then another. "Yes, it must be a herd." Then a fourth, 
and it dawred upon me that they were attacked by robbers-the far-famed Ruga-Ruga.

" "Stay where you are," I cried, and dashed off, closely followed by my boys. The bangs had now reached seven, and we had not the slightest doubt that it was an attack of robbers, and so it proved to be. My anxiety was relieved by seeing our men intact, standing together at bay with a foe that was nowhere to be beheld. I soon learnt that as they were quietly proceeding a party of the savage Wahumba tribe had swooped down upon them; but seeing white men with rifles had fled with the utmost precipitation, without even discharging a poisoned arrow. To make their flight more rapid the white men had fired their rifles in the air; and one in grabbing his gun from his boy had managed to discharge it in such a manner as to blow off the sight of his neighbour's rifle. Finding that danger was at an end for the time being, I begged them to remain as they were ready to receive an attack, while I returned with my boys to Gordon, and got the stragglers together, after which we all proceeded in a body. I have always thought that it was I who had the greatest escape of all ; for had I gone on, as Gordon proposed, with only one, or at the outside two boys, I should most probably have been attacked.

' On July 28th a double march brought me to the second Church Missionary Station, Mpwapwa. The house is a fine one for Central Africa, and the 
prospect in the rainy season must be more beautiful than it was then in the hot dry season. It looks out over a vast plain, the home of many noble herds of antelope and buffalo. Food proved to be rather a scarce article here, as many caravans had preceded us, and they had also had a very trying dry season. Smallpox was raging in the neighbourhood, and not far from us was a native encampment terribly infected, so that we felt it was not wise to delay.

' Six miles from here is an outlying station, Kisokwe, a delightful spot among the mountains and highlands of the Usagara district, which form part of the long mountain chain I mentioned some time ago. Here almost every variety of scenery is met with. There are fine mountain peaks terminating in bare and precipitous crags, and others crowned with luxuriant verdure, while in many places torrents dash down the valleys in a succession of waterfalls, forcibly reminding one of North Devon.

'Game, as I have already hinted, is abundant, and leopards are very plentiful. Hunting excursions, however, are not unattended by danger, for small bands of savage Wahumba robbers traverse the country. Fig trees, which are plentiful throughout East Africa, attain vast proportions in this district. At the end of the garden stands a monarch, spreading his densely foliaged limbs over a space wide enough to shelter a standing army. 
Unfortunately the fruit is not edible. When ripe these figs look inviting and smell nice, but consist of nothing but seeds and rind without fleshy pulp, so that there is nothing for a human being to eat, although hornbills and other birds relish them exceedingly.

'We left this beautiful region by a mountain pass which proved to be very rugged and steep, and very trying for the men. Descending on the other side we entered the third of our divisions, which comprises desert tracks and the plains of Ugogo. It is very different from the one we have just left behind, consisting of broad sandy plains, bounded by low ridges of hills. Wherever there is water it is densely populated, so much so that the plain frequently looks like a broad causeway. Rivers are superseded by ponds and nullahs, which can scarcely be graced with the name of lakes. And it is here that curious isolated granite rocks thrust their weird-looking heads through the alluvial soil.

' Our first experience in this region was not a pleasant one. We had sent our men on before while we dallied with our friends at Mpwapwa. When we reached the summit of the pass we could see various villages with their fires in the plains below, but nowhere was the camp to be discerned. It was a weary time before we could alight on it, and when we did, what a scene presented itself to our gaze! The wind was so high that the camp fires were extinguished, and the men had betaken 
themselves to a deep trench cut through the sandy plain by a mountain torrent, but now perfectly dry; hence our difficulty in making out where the camp was. Two of the tents were in a prostrate condition, while the others were fast getting adrift. Volumes of dust were swamping beds, blankets, boxes, buckets, and in fact everything; and a more miserable scene could scarcely be beheld by a party of benighted pilgrims. It was no use staring at it. I seized a hammer and tent-pegs, forgot I was tired, and before very long had things fairly to rights ; but I slept that night in a dustheap.

'Nor did the morning mend matters, and to encourage us the Mpwapwa brethren prophesied this state of things all through Ugogo. It is bad enough in a hot climate to have dust in your hair and down your neck, and filling your boxes; but when it comes to food, and every mouthful you take grates your teeth, I leave you to imagine the pleasures of tent-life in a sandy plain.

' A day or two after this we arrived at a camp where the water was excessively bad. We had to draw it for everybody from one deep hole, and probably rats, mice, lizards, and other small animals had fallen in and been drowned, and allowed to remain and putrefy. The water smelt most dreadfully, no filtering or boiling seemed to have any effect upon it, and soup, coffee, and all food were flavoured by it. 
'That afternoon I went for a stroll with my boy and two guns to endeavour to supply the table with a little better meat than tough goat. I soon struck on the dry bed of a masika (wet season) torrent. Following this up a little way I saw a fine troop of monkeys, and wanting the skin of one of them for my collection I sent a bullet flying amongst them, without, however, producing any effect beyond a tremendous scamper. My boy then said to me, "If you want to kill monkey, master, you should try buck-shot"; so returning him my rifle I took my fowling-piece.

- Perhaps it was fortunate I did so, for about a hundred yards farther on the river bed took a sharp turn, and coming round the corner I lighted on three fine tawny lions. They were quite close to me, and had I had my rifle my first impulse might have been too strong for me to resist speeding the parting guest with a bullet. As it was, I came to a sudden halt, and they ran away. In vain my boy begged me to retreat. I seized the rifle and ran after them as fast as my legs would carry me ; but they were soon hidden in the dense jungle that lined the river banks; and although I could hear one growling and breathing hard about ten yards from me, I could not get a shot.

'I now had severe attacks of fever every day, and at length we were compelled to come to a standstill, for I was far too ill to be moved. My life hung in the balance for three days. I was 
so weak that the mere fact of a headman in kindness coming in and speaking a few words to me, brought on a fainting fit, and on another occasion I nearly succumbed from moving across the tent from one bed to another.

- After a few days the fever left me, and I was able to sit up for five and ten minutes at a time, and the next day was lifted into a hammock and carried onwards.

' The curiosity of the natives in these parts was unbounded. They swarmed round our tents from morning till night, asking to see everything we possessed, and as they are noted thieves we had to keep an uncommonly sharp look-out. The men are exceedingly undressed, wearing only short goat-skins from the shoulder to the hip-bone. They besmear themselves with red ochre, and paint hideous devices on their faces, so that they look, like red men rather than black. The hair is worn long, is often interwoven. with bark fibre, and is plaited in various fashions, some of which are by no means unbecoming. The Ugogo type of coun-' tenance is for the most part very low in the scale, the features being broad and flat, with but little, forehead. The few handsome exceptions one sees are, I am told, supposed to be Wamasai.

' The women are scrupulously clad, and the many copper and steel chains which they wear are particularly becoming.

'The great feature of the Wagogo is their ears. 
The lower lobes in men, women, and children are pierced. First starting, they begin by inserting a straw or two, or a ring of copper wire; these are gradually increased in number, until at last the ear is sufficiently stretched to allow of the insertion of bits of stick, gourds, snuff-boxes, old

( 1 cartridge cases, and other such articles. From a boy of twelve years old I got a block of wood that he had in his ear, considerably larger than the cork of a gooseberry bottle. Sometimes the lobe is so distended that it hangs down to the shoulder and refuses to hold anything inserted in it; in such a case it is used as a suspendory for fine chains, or coils of iron wire. Sometimes you would see the lobes quite broken down, so that to their immense regret they could wear nothing. I have often been asked to mend their ears; but although I could easily have done it by nipping off the ends and binding them together, yet I always refused so to encourage their vanity.

' I am supposed to be perverse, and so it was, I imagine, that I took a great fancy to these illfamed Wagogo. It struck me that there was something very manly about them; the boys were daubed with war-paint, and were armed with bright spears and skin shields, some of which I could not help coveting a little; but they asked such enormous prices, when anything was said about buying and selling, that I had to forgo purchasing. 
'In some of the places I passed through they had never seen a white man before. They would gather round me in dozens, and gaze upon me with the utmost astonishment. One would suggest that I was not beautiful-in plainer language that I was amazingly ugly. Fancy a set of hideous savages regarding a white man, regarding your uncle, as a strange outlandish creature frightful to behold. You little boys that run after a black man in the park and laugh at him, think what you may come to when you grow old. The tables may be turned on you if you take to travelling, just as they were with me.

- As with other travellers, my boots hardly ever failed to attract attention.

" "Are those your feet, white man?"

" "No, gentlemen, they are not. They are my sandals."

" "But do they grow to your feet ?"

" "No, gentlemen, they do not. I will show you."

' So forthwith I would proceed to unlace a boot. A roar of astonishment followed when they beheld my blue sock, as they generally surmised that my feet were blue and toeless. Greater astonishment still followed the withdrawal of the sock, and the II revelation of a white five-toed foot. I frequently found that they considered that only the visible parts of me were white, namely, my face and hands, and that the rest of me was as black as they were. An almost endless source of amuse- 
ment was the immense amount of clothing, according to their calculation, that I possessed. That I should have waistcoat and shirt and jersey underneath a coat, seemed almost incredible, and the more so when I told them that it was chiefly on account of the sun that I wore so much.

'My watch, too, was an unfailing attraction: "There's a man in it." " It is Lubari ; it is witchcraft," they would cry. "He talks; he says, Teek, teek, teek." My nose they would compare to a spear; it struck them as so sharp and thin compared to the African production, and ofttimes one bolder than the rest would give my hair and my beard a sharp pull, imagining them to be wigs worn for ornament. Many of them had a potent horror of this white ghost, and a snap of the fingers or the stamp of the foot was enough to send them flying helter-skelter from my tent, which they generally crowded round in ranks five deep. For once in the way this was amusing enough; but when it came to be repeated every day and all day, one had really a little too much of a good thing.

' By the 22nd of August we had passed through Ugogo without having paid hongo (tax), a triumph in African travel. And now began the desert tracts.

'What must strike every traveller on entering these plains is the immense quantity of wild fowl. Bustards, king crane, herons, storks, ibis, geese, and ducks abound; but in a land where every- 

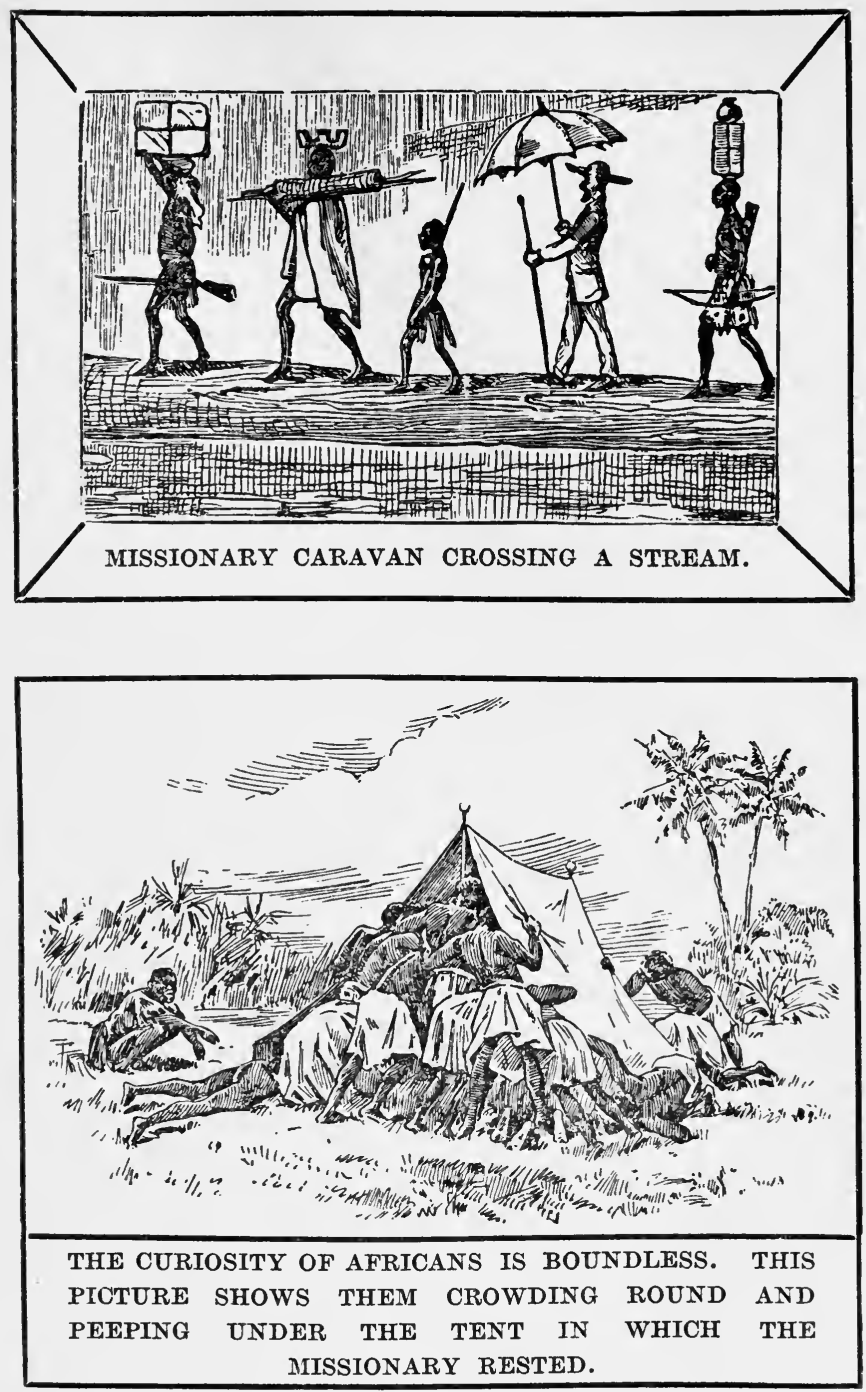

The Illustrations on this page are from Sketches by Bishop Hannington. 

body's hand is against his neighbour's, everything worth shooting is exceedingly wild.

' In the rainy season open breaks in the jungle are exceeding beautiful, blossom almost concealing foliage. In the dry season nothing could be much more dismal than the desert plateau. In some places it was so arid that no bird, beast, or butterfly broke the monotony of a scene which consisted of thin acacia trees at spaces of about thirty yards distant from each other. I have walked for an hour without finding one sufficiently dense to exclude the rays of the sun and afford a little shelter. At other times miles of dense tangle would be traversed, so thick that it seemed to defy even the penetrating power of an elephant, and yet the leafless boughs formed no protection against the rays of the midday sun.

'At times I would arouse my companions with a shout of joy.

" "What is the matter? Elephants ?"

" No."

" "Giraffe ?"

" "No, or I should not have called out."

" "Water?"

" "Not exactly."

" "What then? Come, out with it!"

" A tortula ; a new tortula."

" "What is that ?-a tortoise or a snake?"

" No; a moss. I haven't seen a vestige of moss for a hundred miles."

6 
'“ Oh!" with an emphasis that it would take a long time to paraphrase.

'After six hard days' travelling Sunday came round again, and most gladly would we have accepted the Divinely given day of rest; but it could not be, for food was running short, and to lose a day would be to starve the men. The effect of their provisions being scant began to show itself in their growing rather quarrelsome, for soon after starting I had to rush in and, like Mrs. Brown, stop a tremendous fight with my umbrella. Words had not only waxed high, but guns were about to be used. Your uncle seized one of their guns, but it was some time before I could drag it out of the man's hands ; nor did I feel safe in the skirmish, for a full-cocked loaded gun with weak and worn-out locks is not the safest thing to be wrestling over; but such is life out here-one cannot stop to think what is safe or what is unsafe.

'By the 3rd of September we had reached Uyui, our next mission station. This is a district in the fourth region that I mentioned, namely, the country of Unyamwezi, the Land of the Moon. After this country the well-known range of the Mountains of the Moon was probably called, and seems to have found its way into our older maps from reports obtained from India.

' This district consists of a high plateau, between 3000 and 4000 feet above sea-level, studded with little outcropping ridges of granite, between which 
are fertile valleys densely populated. I estimated that in one valley I passed through there were as many as eighty villages, the smallest containing from two to three hundred inhabitants.

' It is on the crests of these ridges that the granite assumes such fantastic forms. It is hard to believe that they are natural, and are not the cromlechs of a race of giants; but situation and size lead one to the conclusion that these phenomena in stone are the result of deterioration.

- The Men of the Moon are the great traders of the interior, and have probably been so from remote ages. For the love of barter they leave 12 their country as porters, and go to the coast by hundreds annually, carrying with them iron spades, horns, tobacco, hippopotamus teeth, ivory, slaves -in fact, anything marketable.

- They are far more industrious than the generality of negroes. They cultivate cotton extensively, and manufacture it in their own looms; they smelt the iron which abounds in their hills, and work it with considerable skill and design. A Wanyamwezi spade when new fetches a dollar, or cloth to that amount, at the coast.

- As a race they are slimly built, generally intensely cowardly, fractious, and more difficult to manage 2 than the most spoilt of spoilt children.

'The well-known and mighty Mirambo is the Emperor of the Wanyamwezi, having raised himself to that position by his personal bravery. I look 
back to my interview with him with the greatest pleasure, and his answers to questions show an immense amount of intelligence.

' "Mirambo, you are a great warrior, and have conquered in many battles. Tell me which make the best soldiers, young men or fathers ?"

" "If I want to march rapidly, if I want to make sudden and desperate attacks, give me young men, quite young men; they are more active, they are more daring. If $I$ want to defend villages and to stand sieges, give me fathers; they will fight for their wives and little ones and for their goods to the very last."

'A short time before my arrival he had ordered a levy of men to be made in the surrounding villages, as he was wishing to build a new palace. Three men in a distant village made an excuse ; they were ill or absent. The next day or so Mirambo, without any intimation of the fact, arrived in that village, and found them busily engaged with their own work, so he immediately ordered their heads to be struck off. The London Missionary Society's missionary residing there said to him, "Mirambo, our Queen is a great Sovereign. She never does things of this sort," and then he proceeded to explain to him the judge and jury system.

" "Yes," replied Mirambo, "that is very good for your Queen ; she is surrounded by clever gentlemen; but it would not do for me. My people are so = foolish, I can only govern them in this way." 
-When Captain Hore passed through this country on his way to Ujiji, Mirambo gave especial instructions that nobody should raise a finger against his white friend. Now it happened the very night before Captain Hore started from the capital that his headman caught one of Mirambo's pages stealing, and to punish him slightly he tied him up for the night to a post. It also happened that long before daybreak Mirambo was abroad, and visited the white man's camp, where all were asleep, and there he espied his own page in durance vile. He hastily retired, and, when all were astir, he sent down privately to inquire how this came about. $\mathrm{He}$ heard and held his peace until Captain Hore had marched away; he then sent for his page, who had been released, and had returned to the palace.

" "Where were you last night?"

" "Thy servant went no whither," was the unblushing lie.

" "Then I will tell you where you went," so he recounted all. "Now," he said, "I will teach you to disobey my orders, and to molest my white friends."

'So he took a bow and arrow and shot him through the heart, and then, as he did not die instantly, he further took his bow and bowstrung him. It was cruel and severe, but the circumstances of the case must be remembered. Mirambo had given especial orders, and one of his own servants was 
the first to disobey it, and thus laid him open to possible suspicion of connivance. Now it is a noted fact that he never puts anybody to death with his own hand, but always employs an executioner. In this case he made an especial exception in order to show that he had nothing to do with the theft, and meant to stand by the white man, and to prevent his being molested.

'Mirambo's history is too long for me to enter into at any length. He was first called Mtelya, but in consequence of his many victories, he assumed the name of Mirambo, which probably means "Killing many men." $\mathrm{He}$ is further surnamed Nzige or Locust, because it is said that he eats up all before him, and a short time ago he took the name of Malomo-Malimu, or Five Lamps, being the number of important places around him, in all of which he says " he is able to discern between friends and foes."

"Before Mirambo came to the throne he used to get drunk on pombè, the native beer, just as those around him; when, however, he became king, he at once also became a total abstainer, saying, "I could not do all my business and govern my people well, if I drank pombè."

'I was once examined by one of Mirambo's medicine men. This man was of vastly superior morality to the majority of his fellows, who I believe, as a rule, are villains of the deepest dye. $\mathrm{He}$ was, moreover, very good-natured and confiding, nor 
did he appear to be possessed with that spirit of hatred which seems ever to have prevailed amongst the priesthood of heathen systems. He did not hesitate to show me and explain his charms and their uses, and at last it ended in his examining me. For this purpose he used a pair of lazy-tongs, with a little figure at the end, over which he either breathed a prayer or else whispered some instructions. When the doll had peered into my chest, by an almost imperceptible turn of the wrist, it came round and delivered its message to its master. This was repeated twice more, and then the answer was that I had got a cold, which, considering I had been coughing and sneezing ever since I had been in the hut, was easy to guess and hard to deny.

'When we questioned him about his medicine, and asked him if he thought putting a little bottle in the earth and saying a few words over it could make rain, he replied, "Certainly not! Only God could make rain, but how could we expect Him to do so unless we prayed and made the offerings we thought right?" He prayed to God, but he always went away into the forest to do so. We asked if God was only in the forest? No; but it was more retired and quiet.

'Now, lest any should think that this man's own religion was sufficiently enlightened, and he had no need of our teaching, hear the following tale. His son was dying, so he sent a message to Mirambo to say a certain man in his village had bewitched 
him. The answer back was, "You know the punishment for witchcraft (death); apply it." The accused, however, was a desperate character, and nobody dared carry out the sentence, so word was sent to Mirambo, who asked which of his warriors would "undertake the job. All shrank back; but one man, whom I knew well, expressed himself willing to do it. The man was asked to meet him at supper ; the invitation, however, was refused, so he went to the man's house, and stood at his door until he saw him, and was able to shoot at and wound him. The men round then rushed in and speared him to death.

'I witnessed a rather peculiar Dawa (medicine) ceremony amongst the Wanyamwezi. A man solemnly seated himself while another poured some black ointment into his left hand, and then drew his knife and made small cuts, as if to tattoo, first the middle of his forehead and each of his forefingers, the top of his head, each arm, each side of his back, his great toes, each side of the neck, the hip, and back of the tongue. After all the incisions had been made, each cut was lightly touched with the medicine, and the man was ready to journey to the coast, his life henceforth being a charmed one.

' Here is another tale about these same strange people. One day, soon after encamping, I heard a great shout, and started to my feet in time to see a zebra bound through the camp, hotly pursued by a hundred or more men. It was speared a 
few yards from the tents; and then I perceived that mischief was in the wind. A tremendous quarrel ensued. I pushed my way, closely followed by Blackburn, into the surging crowd, and found myself in about as ugly a position as one could imagine.

' On the ground was a beautiful zebra; I was at its tail, Blackburn at its head, and on either side a dense crowd of fierce and angry men quarrelling at the top of their voices; a hundred spears were pointing in all directions. Blackburn at last got the public ear, and ordered the animal to be taken to his tent, saying he would divide it there and arbitrate between them. This gave general satisfaction. The skin he gave to me; but as it had over forty spear-holes in it, we agreed each to take a piece as a reminiscence.

'Then came the headmen, and said that the body must be carried off and thrown into the jungle, for the Wanyamwezi never eat zebra-it was against their creed; if they did eat it, it would very likely break the camp up. Hearing this the hungry men sprang on the prey, tore it to bits, and ran off with it; in the mêlée Blackburn getting rather disagreeably splashed. I had asked for a portion to taste, but this new phase put a stop to my expected feast. Perhaps I need scarcely add the camp was not broken up, nor in any way unhinged.

' By the middle of October I was able to walk from one room to the other, and had had a trial 
trip in my hammock from the mission station of Uyui to the camp and back. I bore this journey well, and although unable to sit up at the end of it, I deemed that the time had come for me to make a start for the lake. That very evening news was brought us that fifty of our porters had deserted, the result being that all was thrown into confusion. However, it never does to be downhearted at misfortunes, so we decided to start, and leave Rashid to follow with the boat and a few odd loads. Sasked me to be down at the camp at 2 p.m., and promised that I should have six porters told off to carry me. I made this a stipulation, as I had already experienced the trial of being dragged along by tired, ill-tempered men.

'In spite of much weakness, I sat up the whole morning and wrote to as many friends at home as possible, for all at Uyui felt that the experiment I was about to make was not unlikely to terminate fatally. At I2 we lunched, and at 2 I entered the hammock, and proceeded to the camp, where all was noise and excitement, for now that these men had departed the question had to be faced, what loads should be taken and what left? I saw that a start was for the present impracticable, and so was carried beneath the shelter of a great rock, and there left until 4.30 p.m., at which time a start was finally made. When the men came to fetch me, I was too tired to think how many or who they were, but before very long I discovered 


\section{IN BED FOR SIX WEEKS}

that I had only one relay, namely, four men in all, and that these, while at Uyui, had been going through a course of dissipation, and had neither power nor inclination to carry me properly.

' I had not gone very far when a large green snake, about eight feet long, came out of the grass and drew himself up in a defiant way, plainly indicating that if we attempted to pass it would be at our peril. My men prepared to drop me and bolt, so I jumped from my hammock and called for my gun, but was not allowed to have it, as they thought me far too weak and ill. Another then fired a bullet from a very respectful distance without any effect; and, wonderful to relate, one of the Wanguana was found brave enough to advance upon the venomous reptile with a stick, whereupon it retreated, fleeing into a hole.

'After about an hour and a half my men began to show signs of utter collapse, and jerked and shook me most painfully. By and by a stumble, and both went down. I had been looking out for this, and so broke my fall ; but it is very dangerous to be thus dropped, nothing being more likely to injure the spine. I gave them a long rest, but it was of no avail ; finally, for safety's sake, I was compelled to abandon the hammock and walk for two hours. How I managed it I scarcely know. I had been in bed for the best part of six weeks, and persuaded myself that I could only crawl from one room to another, and sit up for an hour at a 
time; now I had to walk six miles, or even more. It only proves what one can do if an effort has to be made.

' I arrived in camp at 8 p.m., where sad confusion prevailed. S- had remained to see about the loads we had been compelled to leave behind; the consequence was, the men, being tired, took advantage of his absence, and threw down their burdens everywhere. The grass was long, the night pitch dark, and thing after thing refused to be found. In my exhausted condition I had to do without bedding, and, worse still, without food; for we had encamped in the jungle with neither village nor water at hand, and daylight scarcely mended matters, for there could be no breakfast. I refused to start until I had more men to carry me than on the previous day; but although six were scraped together, yet they were not regular carriers, and I was worse off than before. The scenes of the past afternoon were painfully repeated, with the additional distress of want of food. At r.30 p.m., five-and-twenty hours after lunch at Uyui, we sat down to a meal of pea-soup without stock, and flour-and-water dumpling without suet. The next day I declined to stir an inch until I had six good men allotted to me, for my life absolutely depended upon it.

' On Ist November we encamped near the village of a great chief, called Shimami, great in possessions, stature, and power. He was considerably over six 
feet and robust, although not over-corpulent. A man of remarkably fine points. His first overture was the present of a very fine goat, which was followed by some milk, after which came two oxen. Then, having prepared the way in a right royal manner, he came himself to see and to be seen, and to pick up any little treasure that might be presented to him.

' I gave Shimami a few small presents, and among them a pair of blue spectacles. He then departed to the other tents, where he seemed inclined to spend the rest of the day; and so, as his room was rather to be desired than his company, I arrived on the scene, and suggested that he should take me to see his village, and there I would present him with an English hat, which he greatly coveted. To this he readily assented, and we marched off in correct order, namely, in single file, the chief leading, the guest following, then the Kilangori and officers, according to rank.

- When we approached the village Shimami produced the blue spectacles, and said he must put them on. It struck me that this was the right moment to bring out the hat, for I had now accomplished my object, and drawn him away from the camp. Accordingly I presented him with it. His delight knew no bounds ; he put it on, and spectacles and all, strutted off as proud as a peacock. His chief minister discovered that the crown was flattened a little, in the fashion we generally wear 
our wide-awakes. So it was taken off, and erected in a sharp peak; then its rim was bent up au brigand, and altered yet again and again. I was immensely amused, but my mirth only caused greater delight, for in Africa laughter is seldom expressive of ridicule.

'Though this scene was otherwise ludicrous, the magnificent presence of my newly made friend, with his bright coloured clothes elegantly thrown around him, was most effective. When we entered the village every corner had to be explored, and every subject had to be interrogated, in order that they might gaze upon the new costume. I felt quite sorry for the poor chief, because, in spite of all his grandeur, the white man was the chief object of attraction. The royal hut was very ordinary in appearance. I was proudly seated on the throne-a low stool with a wooden hood over it, rudely cut from a single block, joinery being unknown by the Wanyamwezi; any ethnological collection would be as proud to possess this rough seat as was Shimami.

- After sitting a short time, I suddenly took my leave before his majesty could even rise from the ground, and I slipped round the corner and out of the gate of the village opposite to that at which I had entered. Can you believe it ?-when I came round the camp side of the Tembe I saw the same pompous procession, only altered in two respects-its face was turned the other way, and 
it lacked my figure, for that was at that moment hiding behind a bush! My object was hopelessly defeated.

'Every day for a week after this we had interesting marches, and health improved sufficiently to allow me really to enjoy life.

- In my next I shall take you all for a paddle on the mighty Nyanza. 


\section{Chapter VI}

\section{AT THE GREAT LAKE: HANNINGTON'S NARRATIVE CONTINUED}

- GAVE you a brief outline of the three months' 1 journey I took from the coast to the country of the Wanyamwezi, and there I was obliged to say farewell. You will remember that I told you that we had to traverse five well-defined regions, the physical features of which vary very much the one from the other. Four of these I have already described, so now I am going to tell you a little about the fifth, namely, the Lake District, which nurses in its bosom the mighty Victoria Nyanza, that vast expanse of water which I believe is next to, if not the largest, lake in existence. However, up to the present time we have had no very accurate survey of its dimensions, so that we may have to alter our opinions a little.

'As to the district, it is, as might be imagined, far more remarkable than any of the other four.

'The plateau of the country of Unyamwezi gradually slopes away to the basin of the Victoria 
Nyanza, and gradually, too, becomes more and more fertile until you find yourself in a land literally flowing with milk and honey, and teeming with all manner of life.

- With regard to the people, it is difficult to give any detailed account of the inhabitants of its shores, because they are divided into so many tribes. Clothing at the south end of the Nyanza is very lightly esteemed by men and unmarried girls. The national costume consists almost entirely of skins, many of which are badly tanned, and intensely greasy, and smell most horribly. We were compelled at times to be ungallant enough to have the ladies driven from the vicinity of our tents, for their robes being more ample in dimension than the men's, were consequently more effluvious.

- The villages are frequently situated on the brow of a hill, and the beehive-shaped huts ofttimes nestle amongst picturesque groups of rocks and shady trees, and are surrounded by euphorbia hedges and stout fences. It is customary to ornament these fences with the skulls of enemies slain in war, though sometimes a more lofty spot is chosen, in the shape of a neighbouring tree. Such trophies announce to the visitor who happens to be passing by that a warlike chief lives within; and if he does not look out his head may be seen ornamenting a spare bough.

- After the deplorable massacre of Lieutenant 
Shergold Smith, R.N., and Mr. O'Neill, on the Island of Ukerewe, their heads were found by my fellow-traveller, $\mathrm{S}-$, thus put over the gate of the town, and were bought by him, and buried in the grave of Dr. John Smith, at Kageye.

' One day, in passing through a country where they were at war with some neighbours, I almost stepped upon two dead bodies, one of which was headless, and was doubtless that of a chief, whose head had been taken to ornament the gate of the village.

' When shortly after I arrived there I found the greatest excitement prevailing; the drums were being beaten furiously, and an aged warrior was addressing a ferocious-looking band of younger men, and, to make himself look the more savage, he had taken a piece of brain, which I strongly suspect had been extracted from the head of the murdered man, and had tied it on to his hair, and there it was hanging down over his eyes while he spoke. A more disgusting picture of degraded savagery I never beheld, and I think, somewhat fortunately for me, I could not fully understand the address that he was delivering to the murderouslooking gang around him.

'This region we entered when we arrived on the 8 th of November 1882 at Kwa Sonda, the last village under Mirambo's jurisdiction, and the long-promised spot where we were to behold the waters of the mighty Nyanza. The first impression was one of utter disappointment; we expected to see a grand 
expanse of water and luxuriant foliage, instead of which there was a sandy plain, and in the middle of it, for these parts, a singularly unpicturesque village. Nor could we gather from the natives our exact position and whereabouts. Some cried one thing and some another. The greater part seemed never to have travelled northwards, on account of hostile tribes, and, therefore, to know nothing about the countries beyond them more than that Romwa, Sultan of Uzinza, lived to the north, and had canoes; that the Sultan of Urima reigned over the country to the north-west, and further, that their peoples were very savage, and often at war with their neighbours. It was very puzzling to know how to proceed, the more so as our long journey from the coast had considerably reduced our stores. We really had not the means to explore right and left, as we should gladly have done. We therefore determined to remain where we were until joined by a small caravan that was following us.

'In the meantime I must relate one or two of my expeditions with a gun, for although I never went out on what you might call a hunting excursion, yet I frequently spent an hour or two searching for food, and some of my adventures were slightly stirring.

' For instance, one day I had had a very worrying time with the natives-and they can be worrying if they try. At length I said to a boy, "I shall 
get out of this. I will go for a walk; give me my butterfly-net, and you carry the gun for safety's sake." As usual, near the lake, I had not gone far before I sighted game. A fine bluebok was grazing a short distance from us, but I said, "No ; I do not feel up to the exertion of stalking it," so turned away.

( 'Presently, while hunting for insects in short mimosa tangle up to the knee, I disturbed a strange-looking animal, about the size of a sheep, brownish colour, long tail, short legs, feline in aspect and movement, but quite strange to me. I took my gun and shot it dead-yes, quite dead. Away tore my boy as fast as his legs would carry him, terrified beyond measure at what I had done ! What, indeed ? you may well ask. I had killed the cub of a lioness! Terror was written on every line and feature of the lad, and dank beads of perspiration stood on his face. I saw it as he passed me in his flight, and his fear for the moment communicated itself to me. I turned to flee, and had gone a few paces, when I heard a savage growl, and a tremendous lioness - I say advisedly a tremendous one-bounded straight for me.

' In spite of the loaded gun in my hand, it seemed to me that I was lost. The boy knew more about lions than I did, and his fear knew no bounds. I began to realise that I was in a dangerous situation, for a lioness robbed of her whelp is not the most gentle creature to deal with. I retreated 
hastily. No ; I will out with it, children, in plain language-I ran five or six steps; every step she gained on me, and the growls grew fiercer and louder. Do I say she gained ? they gained, for the lion was close behind her, and both were making straight for me. They will pause at the dead cub ? No ; they take no notice of it ; they come at me. What is to be done?

'It now struck me that retreat was altogether wrong. Like a cat with a mouse, it induced them to follow. Escape in this manner was impossible. I halted, and just at that moment came a parting yell from my boy, "Hakuna! Kimbia!"

'I thought he had seen and heard the lion and "I lioness, and that, speaking as he does bad Kiswahili, he had said, 'Hakuna Kimbia!' which might be roughly, though wrongly, translated, " Don't run away!" instead of which he meant to say-in fact, did say-"No! Run away!"

I have no hesitation in saying that a stop wrongly read but rightly made saved my life. I had in the second or two that had elapsed determined to face it out; and now, strengthened as I thought by his advice, I made a full stop and turned sharply on them. This new policy on my part caused them to check instantly. They now stood lashing their tails and growling, and displaying unfeigned wrath, but a few paces from me.

' I then had time to inspect them. They were a right royal pair of the pale sandy variety, a 
species which is noted for its fierceness, the knowledge of which by no means made my situation more pleasant. There we stood; both parties evidently feeling that there was no direct solution to the matter in hand. I cannot tell you exactly what passed through their minds, but they evidently thought that it was unsafe to advance upon this strange and new being, the like of which they had never seen before. I cannot tell you either how long a time we stood face to face. Minutes seemed hours, and perhaps the minutes were only seconds ; but this I know, my boy was out of hearing when the drama was concluded.

'And this is how it ended:-After an interval I decided not to fire at them, but to try instead what a little noise would do. So I suddenly threw up my arms in the air, set up a yell, and danced and shouted like a madman. Do you know, the lions were so astonished to see your sober old uncle acting in such a strange way that they both bounded into the bushes as if they had been shot, and I saw them no more !

'As the coast was now clear, I thought I might as well secure my prize, a real little beauty. So I seized it by its hind legs and dragged it as quickly as I could along the ground, the bushes quite keeping it out of sight. When I had gone what I had deemed a sufficient distance I took it up and swung it over my back, and beat a hasty retreat, keeping a sharp eye open in case the parents should 
lay claim to the body, for I should not have been dishonest enough not to let them have it had they really come to ask for it !

'I soon found the cub was heavier than I bargained for, being about the size of a South Down sheep, so I shouted for my boy. It was a long time, however, before I could make him hear. I began to be afraid I must abandon my spoil. At length I saw him in the far distance. Fortunately for me he did not know his way back to the camp, otherwise his intention was to return to the camp, and ask the men to come and look for my remains. The arrival of the cub caused a tremendous sensation amongst the natives; dozens of men came to see it, nor would they believe until they had seen the skin that I had dared to kill a " child of the lioness," it being more dangerous than killing a lion itself. I do not think that I was wise in shooting; but the fact was it was done, and I was in the scrape before I knew where I was, and having got into trouble, of course the question then was how best to get out of it.

'A few days after my adventure with the lions I again took my butterfly-net and boy, and consented gladly to the suggestion of Wise to accompany me for a walk. We had not gone far when we came to a beautiful flowering shrub, covered with insects, and here I should have probably remained for the rest of the morning, had I not been disturbed by an excited summons from the others to come in pursuit 
of a rhinoceros that they had just sighted. "Well," I replied, " rhino or no rhino, I have just sighted a new species of butterfly, and I cannot leave this spot until I have secured it."

'Could anybody be so ignorant of my character as to think that I would give up the opportunity of capturing a new butterfly for a chance shot at a rhinoceros? Preposterous! Well, there I remained until I had caught, killed, and boxed my fly ; and then, with no slight feeling of exhilaration, I seized my gun and proceeded in the direction pointed out to me by my companions.

'Wise had never been face to face with big game before, and was in a great state of excitement, trembling with hope and fear combined. We marched on in single file under cover of a tree, and although Wise thoroughly knows how to use his gun, he was in such a state of high pressure, that I momentarily expected the contents of his barrels to take up their residence in the neighbourhood of my calves.

' I took a hasty glance round the bush, and there, sure enough, I saw a magnificent rhino lazily eating some rich herbage, and taking no notice of our approach. Back I darted under cover, and whispered my instructions to my eager companions. There was another bush about twenty yards ahead ; they were to crawl close behind me under cover of this, and then I was suddenly to emerge to the right hand and they to the left, and all deliberately 
take aim and fire; and if this produced a savage charge, there was the bush to serve as cover.

'It was an anxious moment. How would my companions conduct themselves? Would they dodge, if necessary? Would they stand firm, if firm it must be? "Now then ; are you ready ?""Yes ; quite." "Now for it___"

"We emerged with bated breath; and lo! the rhinoceros had disappeared, and there before us stood, or rather lay, a fallen tree !

'Towards the end of the year the caravan, for which I mentioned we had to wait, put in an appearance in an utterly dilapidated condition; the barter goods, which we had been relying on, having been all expended. I therefore determined to remain here no longer, but to send messengers to Romwa, to find out whether he was willing to receive us. The report that these men brought back was encouraging.

'Christmas Day found us as follows: Gordon very ill in bed; Ashe and Wise tottering out of fever ; and your uncle just about to totter in. We had an early Communion, and thought much of our loved ones at home thinking and praying for us and wishing us true Christmas joy. In spite of our poor plight we felt that we must celebrate the day. So we gave our men a holiday, telling them it was a great day amongst Christians, and that we should further give them a goat. I had a kid killed for 
our Christmas cheer, and Ashe undertook the pudding. That pudding had its drawbacks; for when we went to the flour-box the flour was full of beetles and their larvæ, and we could not get them all out; the raisins were fermented; the suet could easily have been compressed into an egg-cup. Then the pudding was underboiled, and yet boiled enough to stick to the bottom of the saucepan, whereby not only was a big hole burnt clean out of the cloth in which it was neatly tied (we were saved the trouble of untying the string), but also its lower vitals had suffered considerably -in fact, were burnt black-and yet a musty, fermented, underdone, burnt plum-pudding was such a treat to African wanderers, that I, for one, ate three slices and enjoyed it more than ever I remember enjoying a pudding in my life. My only regret was that I could not send you each a slice; you would have liked it so much.

'The first day of the New Year, I883, found us en route for Romwa's land, encamped on the banks of the south arm of the Victoria Nyanza. This was called by one of the earlier travellers " Jordan's Nullah." Here we were fortunate-or unfortunate -enough to obtain the services of a canoe and canoe-men in the employ of Mtesa. The captain of these men-as degraded a ruffian as ever livedwas called Mzee, which is simply the Kiswahili for " old man," or " elder." I translated this name somewhat freely, and called him "Old Man of the 
Sea," for he proved to be more troublesome than the persecutor of Sinbad.

'To begin with, he had promised to start on the 2nd January, but began by declaring that we had brought more luggage than he had expected, and he therefore refused to start unless we paid him more than the original agreement. After a deal of haggling we came to terms. He then turned round and said that the canoe leaked, and that he must take the day to mend it. The fact was he had had an unusually good catch of fish, and wanted to skirmish the country to sell it. Evening came, I saw to the loading of the canoe, and at the same time thrice over cautioned Mzee that I had ten more packages to come.

'At 2 a.m. he called me up and said we must start. Well, unearthly as the hour was, I got up, saw to everything, cooked my brethren some food, had the tent packed and taken down to the boat, when Mzee turned round and said that he had no room for the luggage, and refused to start until daylight. This meant that my poor suffering companions would have to sit about in dewy grass, bitter cold, and biting mosquitoes, for three full hours.

'I resolutely answered, "We must start." Thereupon he and his crew rushed to the boat and began tearing out the baggage. A fearful scrimmage ensued, during which time I trod in a colony of biting ants and was woefully punished. Things got in such a pickle that I did not know what was 
taken and what left, and many packages we could ill spare were left behind.

'At 4 p.m. we got off, a hippo blowing a salute as we started. We had not gone far when a loud explosion startled us, and looking up, I saw two legs of my chair flying upwards. My stupid boy had put his gun, loaded and full-cocked, into the boat, and the jarring fired it off. A new rug was cut in half, the side of the canoe broken, and my poor chair spoilt. Yet how much worse the accident might have been!

' Our next escapade was to rob some natives of a goat. And thus it came about. The Old Man of the Sea spied a goat, and rowed after it to shore. I thought they were simply having a chat or friendly barter, for the goat was handed over as quietly as possible, and on we went. It was not until some time after that it came out that it had been forced from its owner. At my expressing horror I was quietly informed that Mtesa's men are accustomed to act in this way.

' The scenery soon became very varied and beautiful. Cormorants, darters, belted-kingfishers, and a very small blue variety, with a robin breast, constantly crossed our track. Many crocodiles and hippos floated lazily on the surface, and over the purple hills the sun rose in golden glory. We landed on the Uzinza side for lunch. The people had never seen a white man before, and their astonishment was beyond bounds. The canoe- 
men were too wise to misbehave themselves in the face of such numbers, so the visit passed off auspiciously. At sunset we camped for the night. Gordon had to be lifted from the boat. Ashe crept out and at once went to bed. I had the tent pitched; then I discovered there was no firewood. After an hour's search I found a little, and finally bought some more, and superintended the cooking, for the boys were worn out. Then Mzee came and said I must get the things out of the canoe, for it leaked, and I found most of the goods wet. It was very dark, and the air was thick with mosquitoes - they were like the plums in a rich Christmas pudding.

'As I was sitting down to enjoy a well-earned meal, Duta came and called me from the tent and told me that the men had refused to go on unless I would pay them extra cloth, and from what he overheard he believed that they intended deserting us. I went down to see what could be done, but we could arrive at no agreement. I kept silence, sparing my brethren any anxiety. I slept little that night, fearing the men would desert and steal some of our loads, but daylight found them still there. Three valuable hours were spent in haggling, which resulted in my having to pay yet more cloth, and a start was not made until II a.m.

'We had not paddled far before a storm gathered, and we had to put into port, and only just in time, for a fearful hurricane burst upon us. "Down 
(1 rushed the rain terrific," and large waves beat upon the shore, washing up shells and weeds. I should have liked to have slept here, as the day was waning, but no! "Onward!" was the word. Three hippos pursued us, and the hippos of the lake are very savage and dangerous, but the men managed to outdistance them. Vast numbers of crocodiles appeared on the surface of the water. I think I saw as many as a dozen in a shoal. I felt no temptation to bathe! The sun then sank into the west, and we were still at sea. I looked at the pale faces of my invalids, and I looked at the luggage, the tent, my helpless boys, and the savage

- ruffians in the canoe, and my heart trembled.

' It was not until eight o'clock that we arrived at the place where the boatmen intended us to sleep. It was so dark that it was a long time before we could find a break in the reeds through which we could wade ashore, and when we landed we found we were in a place which was so rough and damp that there was no possibility of pitching the tent. We crept on some half a mile until we reached a native hut. Fancy the good man of the house, having retired to rest, being disturbed by a ghost in the shape of the first white man he had ever seen! Fortunately he was not tempted to try my ethereal qualities with a spear, but most liberally said we might occupy the goat-house. "Impossible!" I ejaculated, with something more than emphasis, as I gazed upon a thatched manure 
heap ankle deep in mire. "If you will kindly allow us to sleep within your fence, for fear of leopards, we shall be content."

"Having agreed to this, I hastened to my companions, and with great difficulty got them over the rough ground, and had their huts put up in the open. The native, beholding our sad plight, generously vacated his hut, but, after recent experience, I strongly recommended that we should remain in the open until the rain came on. The instant the canoe touched the shore the men made off, leaving us to do the best we could, while they seized upon all the firewood. Our boys on any occasion of this kind always became useless, so that everything fell upon me, and it was some time before I could manage to get a little food ready.

'At 2 p.m. it came on to rain, and the invalids took to the hut, but I preferred wrapping myself in my waterproof and facing it. When daylight dawned, I found to my utter despair that the canoe had sunk during the night, and that almost everything had been drenched. It was hard to think of one's note-books, barometers, botanical specimens, etc., in this condition. But the man who goes to Central Africa must be prepared " to take joyfully the spoiling of his goods," and to bear the reproach of incompetence.

'Almost superhuman strength at times, I fully believe, was given me; but even that had its 
limit. After a sleepless night, and then travelling from 5.30 a.m. till II o'clock at night, I was unable to unload that canoe, and so it sank. The Old Man of the Sea and his crew refused to bale it out, so I and the boys set to work in the pouring rain, and by II o'clock the weather broke, and I got my friends into the canoe and started. Soon clouds began to gather, but evidently only for soft rain.

'Mzee now announced that he had made up his mind to take us ashore and leave us, - - he had had enough of this journey. We certainly had had enough of him to last for many a long day.

" "Well," said I, " how far should we then be from Romwa's ?'

" "Altogether out of the way."

" "And are there any canoes to be hired there ?"

" "There are not. Mzee says he won't go on."

" "Why, we shall die if we are left in this way."

" "He says he will not go on."

"Then I said in a firm clear voice, "Give me my gun;" and I deliberately proceeded to load it, and pointing at Mzee, I said, "Now will you go on ?"

" “Yes, Bwana, yes ; don't fire."

'And round flew the head of the canoe like magic. Once more we speeded o'er the waves; and a few minutes afterwards his own men were imitating my solemn gestures and laughing at me, though confessing that they were very glad I had made them go on; but I had found out a secret-I was 
henceforth the master, and our lives, it is not too much to say, were saved from danger by one prompt action.

'I now grew generous, and promised the men a goat on arrival if they made no more ado. The offer was received with joyous acclamations, and we paddled into shore for lunch in glee, thinking all trouble over. Lunch finished and a start made, they coolly turned on me and said they would only go to the next village, and then leave us. I made no comment, thinking I would get there first. To my great joy when I landed I found that the men whom I had sent overland had hit upon this spot, so now I had a small army of men to help us dry our goods, pitch tent, and get in order. I further discovered that Romwa's capital was only a short distance from us. A runner from thence brought word for us to proceed to a certain spot next morning, and there to await a canoe from Romwa.

" "Trouble surely is ended!" we cried; but was it? No. After being detained two days while Romwa made medicine and consulted oracles as to whether the white men would harm him, the Delphian reply was, "The white men are good for you and your people, but injurious to medicine men." During this day I failed with severe fever, but could not give way to it, for somebody must see the matter through. I only remember suffering more pain, but I buckled myself together, saw the canoe loaded, and made a start. 
'No sooner had we got fairly off than I perceived there was a terrible leak in the canoe, and that the canoe-men were drunk. We landed and repaired the mischief, and the men plied themselves with some "pombè" (native wine), which they had brought with them. The consequence was that when we started they were worse than ever, and yelled and screamed till my poor companions felt overcome by the fearful noise. The captain then stood up and executed a war-dance on a bale of goods, ending by falling on me. This was more than I could stand, so I gave him a needed warning, and said next time he should have a cold bath. Thereupon he grew wrathful, and ordered the canoe-men to land us on a desert shore. This they refused, fearing Romwa, and perhaps my wrath more than the captain's. Then a free fight commenced, which ended in the captain falling overboard. $\mathrm{He}$ climbed in, and in a dreadful rage seized a paddle, and, as I thought, aimed a heavy blow at Ashe, which fortunately just missed, but shivered the paddle completely.

' Believe me, ill as I was, I bounded from my seat, seized him, dragged him into his seat, and defied him to move. I was proceeding to arm myself for protection if necessary, when one of my men took me and gently forced me into my seat, and then proceeded to pat me on the back and talk in this fashion: "White man, be 
calm, be calm; gently, gently; don't disturb yourself. We will go on; indeed we will. White man, be calm; quietly, quietly, quietly;" and with each word administering a gentle pat, until at last I fairly burst out laughing, and the April shower of wrath fled before the sunshine of mirth.

'January 9th saw us settled at Romwa's. It was a lovely spot. We had pitched our tents on a rocky eminence clothed with beautiful foliage, and from whence we gazed out on the broad expanse of that mighty inland sea.

' Romwa himself, like a good many of us, was not so agreeable as he made himself out, and soon began to try and extract from us the few remaining goods that we had in our possession. Superstition of the most degraded type was rampant, and every corner of the land full of the habitations of cruelty, and all that one saw forcibly told, in language too plain to be misunderstood, of the great need, yea, and opening, that there is for Christian missionaries to teach these poor degraded savages the ennobling and saving truths of the Gospel.

' For some time at Romwa's we seemed to be State prisoners, and could not tell when he would permit us to leave. However, at length he consented to my proceeding, providing the others remained. I accordingly started (22nd January) with two boys. I had had severe fever the day before, and did not feel up to much fatigue. However, I got up early and went down to the royal 
hut, and was kept waiting for an hour while I was inspected by the king's wives ; then another hour was spent at the water's side, so that it was not until II a.m. that a start could be made. Then hindrances arose and we had to put into shore. Then came a storm, and the canoe sprang a leak, so that by 5 p.m. we had only accomplished an hour's work.

' Once more we put to sea, and encountered another storm which drenched all my blankets. At midnight we crept quietly ashore, uncertain whether the natives were friendly or not. I had my wet bed and blankets conveyed a little way from the swamp belt of the lake. The boys and men feared to remain with me thus far from the canoe, so I laid my weary frame to rest under my umbrella, for it was raining.

' Unmindful of natives or beasts of prey, I fell asleep. Soon a tremendous roar close to me caused me to start in a way that no nightmare has ever accomplished. What could it be, a lion? No ; lions are not so noisy. It was only a hippopotamus. He had, no doubt, come up to feed, and stumbled nearly on top of this strange object-a white man with an umbrella over his head, fast asleep. So bellowing out his surprise, he turned round and ran to the lake.

' Before daylight dawned we were off, and soon after reached Kageye. I was welcomed by the Arab chief, Sayed bin Saif, and as I was seated 
sipping some delicious coffee, a strange white man stood before me. I sprang to my feet, only to hear, "Bon jour, monsicur," and then I knew that I was in the presence of one of the French Jesuit priests.

' I started on 3oth January I883 with my two boys and six men, leaving your cousin in Kageye to wait for my return with the baggage left behind in Msalala. I had to cross Urima, in parts of which they had never seen a white man before. It was a bold undertaking, but I had no fear of being molested by the natives, simply because I could see no reason for their interfering with me.

- However, when first I set foot in Urima about 200 armed warriors turned out and surrounded me, and I suspect that the least show of resistance, or on the other hand of fear, would have been followed by fatal consequences. They peremptorily ordered me to stop and pitch my tent, and then they surrounded me by a cordon of armed men to see that I made no escape. In the meantime they despatched runners to the Sultan of Urima to tell him that they had captured a white man, and to ask what they should do with him. I was kept in this durance vile for the whole day, but I punished the rough soldiers around me, and myself not a little, by sulking within my closed tent, so that they were unable to inspect either me or my things.

' Just before sunset an ambassador arrived from the Sultan demanding a present. I assured him that I had nothing suitable with me, whereupon he 
replied that he must be assured that I spoke the truth. So accordingly I had to show him all I possessed. At my blanket-you know my blanket, for fifteen years it has been my companion-he paused. "He must have that blanket, Bwana Mkubwa, great master." I cried, " The white man is cold; he wants much clothes. If you take his blanket he will die. When the sun is gone to rest the white man grows chill. Leave him his blanket." The earnestness of my eloquence prevailed, and the next day he permitted me to depart, providing that a messenger accompanied me to receive the promised present.

' Then arose a question about canoes to cross the nullah, and these at first were denied, but after a great deal of palaver my arguments again prevailed. A council of war on an occasion of this kind was really a grand sight. I would sit on my bed in the tent and have both the doors flung open. Then the ambassador would take the seat of honour, and near me would sit my headman and boys, and near him his chief attendants, while outside and around the doors would crowd breathless listeners. I would then tell my man in Kiswahili what I wanted, and this he would translate in Kirima to the ambassador, only adding volumes to it of his own to put it into proper shape. He would say three or four words only at a time, snapping his fingers between each sentence, and further pausing for the audience to exclaim, "Baba." 
'Here is an example: "The great white man ('Baba!') has come a long distance ('Baba!'). $\mathrm{He}$ has come to see the black man ('Baba!'). $\mathrm{He}$ has come to teach the black man ('Baba! Baba! Baba!'). He asks the black man to be kind ("Baba!')" (rather feebly), and so on, and if he spoke for an hour no one would move or interrupt or object until he had concluded.

- Then all eyes would be turned to the ambassador, who in the same solemn way would state his objections. I think you would have liked seeing and hearing one council, but I doubt if you would have sat through a second; and when it came to two or three times a day you would have kicked over the traces, and the consequence would have been that the ambassador would have sent down a man to say he was busy that day, and would talk again in three days' time. The patience required to deal with savage Africans is almost superhuman. Still, in spite of everything, I arrived once more in Msalala.

' I had a long consultation with the other missionaries, which ended in my immediately starting for the coast. ${ }^{1}$

"It was a bad time to travel, as the "big rains" were almost upon us, and they make the country very wretched. However, there seemed nothing

1 This means that Hannington's health was so desperately bad that his colleagues refused to allow him to go on. See next chapter. 
to be done but to face the worst, and make the best of it.

'We started at daybreak on 22nd February and marched through jungle until we reached a plain. There I had at once to plunge into thick grass, higher than my head, and wringing with dew. Under foot was water, in most places up to the ankles. And where it was not water it was filthy black mud. I never had such a walk in my life, and the men with me, who have travelled all their lives, said they never had.

'When we reached the first village we found that all the inhabitants had fled, and carried all their goods with them, since war was raging in the district, one poor old blind woman being all that was left behind, and she just struggling off to a neighbouring town.

- Before reaching camp one of those tropical showers of which you so often hear came on. I struggled on, and took shelter in a native hut; even here I had to sit with my umbrella up, for it leaked very badly. While the ground was running with water my men, in mistaken kindness, put up the tent; the consequence being that the floor inside was much in the condition of the path I had been travelling, and my bed, on which for hours I had been promising myself a good rest was too wet to use.

'As we marched on we fell in with many rivers and morasses, and the rains became so heavy 
that I doubted whether I should be able to proceed much farther. There was often an immense deal of water on the road, sometimes ankle, sometimes knee-deep, and sometimes I have been carried for the best part of an hour with the water up to the men's chins. In cases of this kind I used to cling round the pole of my hammock, and six men would carry me on their heads as if I was a log of wood ; but it was by no means comfortable, although far better than getting wet.

'My mode of being carried across deep streams was of a novel character. You must imagine your uncle kneeling on the shoulders of a tall, powerful man, and resting on the shoulders of another in front, while a third behind has grasped him by the feet, to steady him. In very swift streams sometimes six or eight men were requisite to keep the three bearers from being swept away, uncle and all.

'These rivers and floods used to keep me in suspense lest in my weak condition I should be plunged headlong into the water. But far worse than the rivers were the morasses. For a mile together have I been borne through the most horrible black mud, often above the knee. This was exceedingly fatiguing for the men and trying to me, and the more so as I knew I was inhaling malarious poison of the worst description.

'Then again, coming from the lake to Urombo, I was at the mercy of men whom I had to hire 
- perhaps for a spell of three days ; they would carry me two days, and the third day bolt, and leave me in the lurch. On one occasion, when only fit to be in bed, I had to crawl fifteen miles. And yet again, when scarce able to stand or sit up without being kept on my feet by my boys, I had to drag my weary limbs six miles. My men used to say, "Master must die, but how is it master is so cheerful and happy through it all ? Black man would lie down by the side of the road and die like a sheep."

$=$ "At length, through another desperate attack of fever, I had to take altogether to my hammock. It sounds wonderfully luxurious to talk of being transported from place to place in such a manner. Well, all I can say is, let anybody try it, and see if they care to repeat the dose. I think I could write a book on the subject, I have had so much of its excitements, its monotony, and its discomforts.

'Let me mention just a few of the delights (!) of this method of locomotion, for your benefit. Upon one occasion the man in front fell down flat, and by some miraculous means was pinned to the ground by the hammock-pole; nor could he move until a companion released him from his strange position. Sometimes the man behind tripped up ; in which case I fell on the back of my head. Another time he glided on to his knees in several inches of black mud. And yet again both 


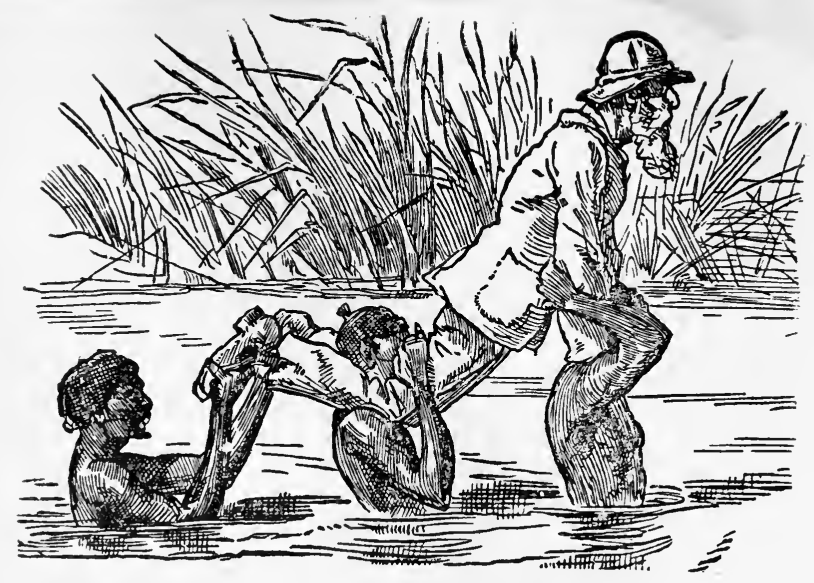

CROSSING A STREAM.

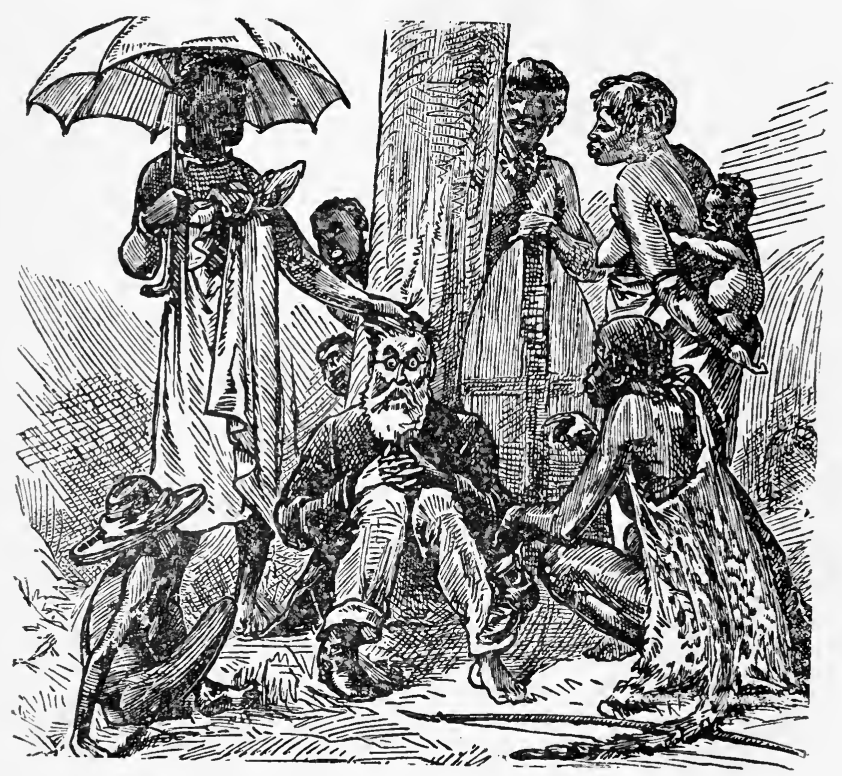

PERSONAL ATTENTIONS FROM THE NATIVES.

The Illustrations on thìs page are from Sketches by Bishop Hannington. 

bearers simultaneously tripped, and a complete downfall took place.

'Further, you are asked to imagine boughs whipping one in the face, or men banging you against a sharp-pointed stump of a tree, or passing over rough ground, and being jumped up and down like a pea on a drum, and yet these were everyday occurrences. And as for being lifted over and under fallen trees, and being handed down deep ravines and up the other side, with one's feet far above one's head-why it happened so often that I grew accustomed to have my heels high in the air.

' I have already dilated on the horrors of crossing streams and floods and mud pools and swampsfirst one man and then the other slipping and tripping and sliding, and stumbling and gliding and tumbling, and keeping one in an intense state of agitation, let alone discomfort beyond imagination. One good man who carried me had a kind of springhalt, which was particularly unpleasant, especially after a meal.

'Altogether I had a nice time of it, and one of the most suffering things about life in a hammock was the fact that I was a mere bag of bones, having been reduced from twelve to eight stones in weight by repeated attacks of fever.

' I will now give you a description of my tent and its contents. We begin at the pole, around which are fastened about twenty spears, besides a bow, one of my guns, and a native sword. Then we 
come to the pantry, which contains a native box made out of bark, a saucepan, bucket of water, and the two provision boxes; on the top of the little one, my lamp; on the other, a cup, etc. The best box stands on two fine elephant tusks, to prevent its being eaten by the white ants. Leaving the pantry we come to the wardrobe, which, besides the bags for my clothes, has also a load of shields. Under some leopard and other skins you would find a load or two of cloth for barter, and, stowed away in a corner, a number of native clubs. Then as we pass on we come to the dining-room and bedroom; on my bed is my favourite old blanket which has accompanied me in all my wanderings for fifteen years, and to my mind it looks as gay as ever it did. The three boxes are respectively medicine, despatch, and lamp-box. They act as my table, but as they are not very large, if you come to a meal with me, we must put some of the things upon the floor.

" "Now, boy, bring in my tea."

" "Yes, sir ; coming."

'Let us see what we have got. First, two eggs, which, with the salt and our one teaspoon, he puts down before us. Now, mind I don't forget to help myself to salt first, because I have only one spoon. Having finished my first egg, the boy comes again. " Kettle boils, sir."

$$
\text { " "Well, make the cocoa." }
$$


'Then I wonder which will be best, to let the water or the egg get cold; finally I decide, as I have no bread-and-butter, to finish the egg, since it will only take a very short time to eat. I then hand over the spoon to be taken to the camp and washed, only hoping that he will not forget to do so. Perhaps you noticed as I ate my egg that I was not burdened with an egg-cup, and that I had to hold it in my handkerchief; but I did not like its running over the side, for run over the side it would, because African eggs are only the size of bantams' eggs, and our spoon, not being a silver one, has had rather an extravagant expenditure of metal laid out upon it.

' Eggs finished, I proceed to rice porridge-my standing dish. I may speak of myself having lived upon it for three months. The spoon having again been cleaned, I forget that I am going to be extravagant, and have jam, and so plunge it into the rice. Dear me! shall I lick it clean, or wait while the boy washes it? Don't tell anybodyI'll lick it. Having dived into the jam, I taste the cocoa. 'Tis very weak, and I see all the cocoa has sunk to the bottom of the cup. Where is the spoon? 'Tis jammy! Never mind; lick it again, and don't tell. Then allowing ourselves two sweet biscuits we conclude our meal, and, seizing pen and ink, we begin to write our letter.

' I passed the two big Poris (deserts), and at length arrived at Kisokwe, the home of $\mathrm{Mr}$. and 
Mrs. Cole, and a little English baby, at this time five months old, the first born in these parts. Both Mr. and Mrs. Cole are earnest and devoted missionaries. Mrs. Cole has a large Sunday-school class. Its members form such a quaint group, I should like you just to look in upon them one Sunday afternoon. Some were very gaudily clothed in all sorts of bright colours, some merely in goat-skins. Others, again, were red with war-paint, and carried bows and arrows or spears. Altogether it would be difficult to imagine a more quaint and yet picturesque group of children; and yet, for all this funny appearance, they were very respectful and orderly, and tried to learn the great lessons which Mrs. Cole endeavours to teach them.

' Here, in addition to my other trials, I lost a friend, who, like me, was returning to England for his health. He died very suddenly at last, and at the moment of his death I alone was with him. ${ }^{1}$

' Not many weeks after, dear Mrs. Cole, who was so kind to your uncle during his two visits, and who was such an energetic missionary, and so truly devoted to the welfare of the swarthy sons and daughters of Africa, likewise was called away.'

1 Mr. Penry of the London Missionary Society. 


\section{Chapter VII}

\section{THE DARKER COLOURS OF THE PICTURE}

Hannington makes light of Privations and Sufferings-A Fire in the Bush-Fever-Dysentery-At Death's DoorRecovery-Threatening Attitude of Natives-Life a Burden - Cruel Sufferings-Hannington, compelled to give in, sets out for the Coast-Twice left by the Roadside for dead, and revives-Arrival in England-'Forgive the one that turned back.':

U ANNINGTON'S letters in the previous chap11 ters, full of brightness and vivacity as they are, give but an imperfect picture of his great missionary journey to the Victoria Nyanza. The impression which one is in danger of carrying away from them, that the expedition was something of a picnic, with just spice enough of adventure, discomfort, and danger to make it piquant, would be an entirely erroneous one. The letters are, of course, literally accurate as far as they go; they manifest the blithe, undaunted spirit in which the great missionary encountered difficulties, and as such they are valuable for the insight they give into the mind and soul of an intrepid soldier of the Cross. But who would gather from the 
perusal of them that the enterprise frequently bore an aspect of tragedy and horror? Yet such is the undoubted fact. The details that follow, collected from Mr. Dawson's biography, will serve to complete the picture.

A few days after the start into the interior the high grass round the camp took fire, and a catastrophe was barely averted. Hannington's men, having discovered that the fire was caused by the inhabitants of a neighbouring village, went off, armed with gun or spear, or bows and arrows, to wreak vengeance. Hannington tore after them, and was just in time to prevent serious mischief. Only one man had been wounded with a war-club in the head. Hannington doctored him, and further soothed him with a dollar.

In the middle of July all the party except Edmonds were laid low by the dreaded fever, the scourge of African travellers. 'Fever is trying,' wrote Hannington to the C.M.S. Committee on Ist August, 'but it does not take away the joy of the Lord, and keeps one low in the right place.' Five days after this his temperature reached IIO! he was seized with violent rigors, and then with alarming fainting fits. The fever, a few days later, was accompanied by violent sickness, intense pain in every limb, and burning thirst. 'I had nothing to drink, and my tongue was so hard and dry that, when I touched it with my finger, it made a noise like scraping a file.' 
For all this he was the life and soul of the party, and never let his companions' spirits flag.

Hannington was seized with dysentery at Uyui, a C.M.S. station which the expedition reached on September 4. For ten days he lay at the door of death. The Jesuit priests at Unyanyenbe (the spot where Livingstone and Stanley parted) prescribed an injection of carbolic acid which for a time relieved the most distressing symptoms, but nothing seemed to avail permanently. The other members of the party held a council and came to the conclusion that their leader must be left behind while they went forward. Hannington was left in charge of his nephew, Gordon. Rheumatic fever supervened to the African fever and dysentery, and it seemed that he could not live. $\mathrm{He}$ was in such agony that he asked all those about him to leave him and let him scream, as it seemed slightly to relieve his sufferings. 'Can it be long before I die?' he asked Gordon, and the reply was, "No; nor can you desire that it should be so.'

In the moments of relaxation from his severe distress he was thinking of others, and drew up a small book of information for the guidance of men who should leave home for Africa. $\mathrm{He}$ believed that he himself would certainly die, and had selected the spot where he was to be buried. His favourite hymn at this time was, 'I am coming to the Cross.' 
However, he did recover, and though very weak was in good spirits, insisting upon going forward, were it necessary to carry him the whole way. The expedition had returned to Uyui, having encountered difficulties on the adopted route. They started out again, a united company, in a somewhat different direction. Hannington described himself at this time as ' an empty bottle on the shelf.' On October I6, then, after nearly six weeks in bed, Hannington was on his way again. $\mathrm{He}$ declared that the life was thoroughly agreeable to him. How characteristic of him are the words that follow: 'If I had good health I should be too happy. What wonderful mercy surrounds us! Truly, underneath are the Everlasting Arms!'

Blackburn and Edmonds had been left at Uyui to take the place of Copplestone, the missionary there, who was returning to England. Ashe and Wise were to form a station somewhere at the end of the lake, which the expedition had now reached. Gordon and Hannington were to proceed as speedily as possible to Uganda. What actually did happen we shall see.

The expedition moved forward along the south shore of the lake to meet Romwa, the Sultan of Uzinza. A strange procession accompanied the savage monarch as he went forth to greet the white men. First came a long line of medicine men carrying horns full of rancid butter, then Romwa himself, not much short of seven feet in 
height, then wives, councillors, and another mob of medicine men. As soon as he had seated himself in a chair in the centre of the tent, the horns of rancid butter were placed in the ground all round him to protect him from the white man's witcheries. As an additional safeguard, the Sultan had anointed! himself with castor oil from head to foot. When Hannington told Romwa that he had a handsome robe for him, but no cloth and no guns, the savage rose in a passion and stalked off, saying he was a great chief and would have a great present. The C.M.S. has always refused to make presents of powder or guns or offensive weapons of any sort.

In addition to the anxiety, Hannington had to bear the burden of sickness. The camp was moved up a hill, Hannington managing to walk up, collapsing only twice-as he pathetically remarks-on the way. From the top of a rocky eminence, clothed with beautiful foliage, he gazed out upon the broad expanse of the mighty inland sea. Romwa consented that Hannington should proceed by himself to Uganda, and accordingly on January 22, I883, he started in a canoe with two of his boys. When he reached Kageye two days later he was very hospitably entertained by the Arab chief, Sayed bin Saif, and the Jesuit priests. The latter informed him that the missionaries in Uganda were anxiously expecting his arrival. But before setting out on the final stage of his 
journey, Hannington thought it advisable to return to Msalala to bring up the remainder of the goods. The day after he left Kageye he was again seized with dysentery. He had to walk with his hands tied to his neck in order to prevent his arms moving, as their least motion give him intense pain. Exhausted with cruel suffering, he barely crawled to his friends' tent at Msalala. He confessed himself that he was 'done.' The bright and buoyant figure was now bent and feeble, like that of a very old man. His life had become a burden to him, and he had quite resigned himself to the thought that he would never see England again.

Hannington now made arrangements, with a sad heart enough, for his departure. He arranged that Mr. Ashe should take his place and accompany Mr. Gordon to Rubaga. He established Mr. Wise at Kageye. Then, having put everything in as good order as he was able, and committed his fellow-workers and their holy cause to the hands of his God, he threw himself into the same strong hands and, turning his face away from the great lake, commenced the long and weary journey to the distant coast -800 miles of forest, morass, and desert. Several times, during the journey, he seemed to be at the point of death, and gave himself up for lost. On two occasions the bearers laid what they believed to be his lifeless body on the ground and left it. Consciousness returned and he crawled painfully after the caravan till he 
was discovered. Yet his patience and cheerfulness never forsook him.

An incident at Kisokwe (near Mpwapwa), where Mr. and Mrs. Cole were stationed, reveals the passion of tenderness which dwelt at the heart of Hannington. 'I was greatly affected,' he writes in his diary, ' at the sight of the baby. The thought of my own sweet children filled my heart, and the slight hope I have had, and still have of ever seeing them again all came before me so vividly that $I$ must confess to crying like a child. I rushed at the baby, and begged to be allowed to hold and kiss it.'

Towards the end of the journey to the coast, Hannington was recovering so fast that he had serious questionings with himself as to whether he should not return to the lake; but the doctor who had hurried up from the coast to attend him entirely forbade the project.

Hannington was again among his friends in England on June 10, 1883. But he could not be content until he had retrieved his defeat and reached Uganda. He had seen the need of the Africans and he passionately longed to supply it. 'Forgive the one that turned back' is the plaintive cry of his heart. Forgiveness was not needed. He had done his part, but God had seen fit to deny him the desire of his heart. 
Chapter VIII

\section{BISHOP OF EASTERN EQUATORIAL AFRICA}

The first Bishop of Eastern Equatorial Africa-Hannington's Experiences in Palestine-Enthusiastic Welcome at Frere Town-A very much 'alive' Bishop-Sound Converts wanted-Expedition to Mount Kilimanjaro-The Bishop joins in a native Dance-The Rescue of Eight Slaves-The same Water for the Bishop, the Dog, and the DonkeyThe 'bewitched' old Woman-Mandara's naked WarriorsSplashed with Sheep's Entrails-A narrow Escape from Death.

H ANNINGTON settled down to his work at Hurst again as though he had never left it. But when he felt once more in bounding health, the desire to return to Africa returned upon him in tenfold strength. The medical board of the C.M.S., however, gave him little encouragement. The verdict of the doctors on October 8, 1883 , was 'Africa NEVER.' But Hannington could not be repressed. Although he was told not to come back again for six months, he presented himself in less than two! The decision this time was that he might go anywhere except Africa and Ceylon.

$\mathrm{He}$ was greatly encouraged, yet not satisfied, 
for Africa was the desire of his heart. He had the instincts of a soldier or a sportsman; Africa had beaten him and he was resolved, God willing, to beat Africa. His character in the meantime had been softened and mellowed, he was as full of fun and humour as ever, but, says Mr. Dawson, who speaks from personal experience, he was gentler and more tender, quieter, and more outwardly affectionate in his manner.

The improvement in his health continued, and great was his joy when Sir Joseph Fayrer, the climatologist, gave it as his unqualified opinion that he might now return to Africa with a good prospect of being able to live and labour there for many years.

The C.M.S. had for some years been revolving the idea of placing the mission churches of Eastern Equatorial Africa under a Bishop. The cause of the Gospel had taken root in various localities throughout this immense tract of territory, and there was a reasonable hope that it would grow into a goodly tree, under which many souls would find sustenance and shelter. What was now required was that 'the widely scattered churches should be bound together by the personal influence of one who would have authority to command, wisdom to organise, and character to ensure that his commands should be obeyed.' The eyes of the Committee turned towards Hannington, and the position was offered to him. $\mathrm{He}$ saw in this 
the answer of God to his heartfelt petitions that he might again serve Africa, and he accepted. Accordingly he was consecrated in the parish church of Lambeth on June 24 , I884.

Bishop Hannington left England for the last time in November 5 of the same year. He had been charged by the Archbishop of Canterbury to visit Jerusalem on his way out and confirm the churches. He was compelled to wait five weary days in quarantine at Beirut. But the Bishop never lost time. He was fully occupied with correspondence and the study of African languages. While in Palestine he lived in a whirl of activity. Few travellers penetrate to the Hauran, the desert country, infested with Bedawin, beyond Galilee in the east of Jordan. The Bishop knew no fear and escaped unscathed. He described the modern Jerusalem as vile, and the sites as chiefly fictitious. $\mathrm{He}$ informed his wife that his status of Bishop caused the people to stand rather in awe of him; ' but I am sure they need not,' he added, 'for I am an exceedingly meek and unpretentious individual.' Yet they loved him, and everywhere complained that his stay was too short.

The voyage being resumed, the Bishop and his chaplain reached Aden, where they exchanged into the 'Baghdad,' bound for Frere Town; it was to be the seat of the Bishopric. 'My heart sank,' he wrote, 'as I smelt the cockroaches and bilgewater.' However, the voyage was much more 
pleasant than he had anticipated. At Frere Town (which is situated on the mainland and separated by a narrow channel from the island of Mombasa) a thousand people came to the shore to greet him on January 24; guns fired, horns blew, women shrieked, the Bishop laughed and cried. 'Altogether,' he says, 'there was a grand welcome, and the moment we could get a little quiet we knelt down and thanked God.'

The fellow-workers over whom the new Bishop exercised authority consisted of twelve clergy, priests and deacons, eleven laymen, and four ladies, wives of missionaries; twenty-seven in all, scattered over an enormous extent of country.

Bishop Hannington began his work at Frere Town. His feelings of anger and shame were aroused by seeing that the houses of the missionaries were superior structures to the church. 'We must have a decent church,' he wrote, ' not a tin ark, or a cocoanut barn, but a proper stone church-a church to the glory of God.' He at once issued an appeal for money for the new church.

The place of worship at Frere Town was crowded with a very well-behaved body of worshippers who seemed to realise the purpose for which they were gathered together.

The Bishop found that the mission steamer, the 'Henry Wright,' was in a very filthy condition, and set about altering this.

$\mathrm{He}$ was ubiquitous and indefatigable. No one 
knew where he was going to turn up next, and this kept everybody on the qui vive. Suddenly, while believed to be far in the interior, he would reappear in the streets of Frere Town. It was well for his colleagues that they were animated with a spirit like his own; for a man at all inclined to be lazy would find the Bishop a very uncomfortable sort of person to be associated with.

Bishop Hannington was insistent that the missionaries should make it their first business to seek spiritual results from their labours. These are frequently so difficult to attain, so slow in arriving, that the temptation of workers is to devote more than a legitimate share of their attention to educational work, or merely to civilising. Hannington paid a visit to Bishop Smythies of the Universities Mission at Zanzibar, and was gratified to find that ' with all his ritualism he is strong on the point of conversion, and is very particular about baptism and communion not being administered before conversion, either to heathen or professing Christians.' He felt strongly that all the native Christians who preached in the regular church services ought to be examined by him, that he might judge whether they were really fit to teach. The Bishop was above all things anxious to have sound converts and sound native preachers and teachers.

Hannington sometimes showed his impatience at excessive anxiety about the economical admin- 
istration of the work. 'I want to hear more about saving souls than saving pice. I should like to know that the weeds are being pulled out of the hearts, while those in the shambas are not permitted to run wild.' He regretted that he did not see the souls of the boys in the school being reached as he could wish. Further, he wanted the most intelligent boys to be prepared for the ministry, for teaching, or the medical profession. Half in fun, half in earnest he complained that letters from Salisbury Square ${ }^{1}$ were so ' awfully official ' that they contained no spiritual lozenges to revive the workers on the field. "Would not some dear Christian soul in the Committee undertake to write us religious letters, and enclose little leaflets and choice crumbs-inquire after our souls, and draw out the depths of our heart ?'

We are now about to give some notes of Bishop Hannington's great expedition to the Kilimanjaro mountains in the spring of I885. We may say here that the interest of the story of this, as of the other Gospel adventures of Hannington, will be heightened if the reader will follow it with the map of Eastern Equatorial Africa spread out before him.

Hannington's object when he set out was merely to inquire into the state of things at Taita, the farthest advanced mission just along that route westward, and separated from the coast by some

1 Where the mission-house of the C.M.S. is situate. 
200 miles of horrible, waterless desert. There had been a famine in that land, for which the natives were inclined to attack the missionary stationed there as the cause of it, although his own flock had suffered severely. Although the difficulties of caravans were frightful, supplies of food were sent up from Frere Town, and many lives were thus saved.

The first C.M.S. station on the way was Rabai. Here the people were expecting the Bishop, and a tumultuous welcome awaited him. During four whole hours nothing went on but the firing of guns, dancing, and shouting. The Bishop joined in one of the dances, to the intense delight of the natives. He gave a great feast, which was attended by about 600 guests. Hannington's boys were caught stealing, and as a punishment were tied up all four to separate posts, in sight of the banquet. But the good Bishop was more pained than the boys, his heart relented, he released the boys earlier than he had intended, and the next day they stole the sugar! Hannington preached to a crowded congregation on 'What must I do to be saved ?'

The caravan mustered about Ioo, as it had to carry a month's food for the starving people of Taita. The Bishop laid aside gaiters, shovelhat, and apron for the journey, busying himself in the work of the camp and teaching the native porters and attendants their business. After passin 
through varieties of country, most generally, however, desert or jungle, he arrived at Taro, where, for a mercy, there was plenty of water, 'if you don't mind toads and tadpoles and suchlike denizens of stagnant pools.' Here eight slavesa woman and seven children-were rescued from a gang of Swahilis who fled in fear, leaving their prey behind. The poor creatures were more than halfstarved; they were sent down to the coast, freed, and received by the mission. But so cruel had been their treatment at the hands of their oppressors that they all died but one.

The dreaded Taro desert, a veritable land of death, wherein reigns a dreary and an eternal silence, is the most trying part of the journey to Taita. The road passes through closely packed thorn bushes which tear the clothes and flesh and do not afford a particle of shade. The traveller can see only a few yards ahead. "How little we appreciate our comforts at home!' exclaims the Bishop,- ' the blessing of a wash, for instance. No water means almost no wash. Being an old traveller I meet the difficulty by filling my sponge before starting, and tying it tightly in its bag. If we have two days without water, the first day I have what a schoolboy would call " a lick and a promise"; then the second day I wring out the water, and get quite a brave wash, the water afterwards coming in for the dog and the donkey.'

Mr. J. A. Wray, the missionary at Taita, was 
found in a state of semi-siege. The Wa-Kamba had attacked and burned villages in sight of him, and for two days he and his people had been on guard. The arrival of the Bishop with the muchneeded food was a great relief to him.

Hannington pressed forward beyond Taita. In a very vivid, spirited, and rapturous style he describes his first glimpse of the mountain he had come to occupy in the name of the Lord: 'As we topped a rise, suddenly before our astonished gaze flashed Kilimanjaro in all his glory! How lovely the great mountain looked-all radiant with the rays of the rising sun. We had, by the best fortune, arrived at this point of vantage just at the hour of sunrise, when the vast silver dome for a short time shakes aside the mist wreaths which during the rest of the day so frequently enswathe his snow-crowned summit. The sight was so surpassingly beautiful that it called forth long and loud exclamations from the stolid Africans around us, many of whom were well acquainted with the snow giant. That an African should exclaim, or even take note of any natural scene, however grand, is something quite uncommon; but now all, black and white alike, were in ecstasy at the magnificence and beauty of the sight. We at once called a halt, and, as long as time permitted, we feasted our eyes on snow under the burning sun of Africa.'

This great journey, though free from serious 
danger, and during which Hannington, on the whole, enjoyed excellent health, was fruitful of striking incidents. At the village of Burra, passing a foot-track which led in the wrong direction, Hannington, according to custom, drew a line across it with his stick, as a signal to those behind not to go that way. An old woman who happened to be standing on the path was seized with a paroxysm of terror. She was fully persuaded that the mysterious conduct of the Bishop was designed to bewitch her, and raised the most fearful shrieks, calling on all around to kill him. Through the wood and over the hill rang her shrill cries. Nothing could pacify her, so not knowing what might come of the matter Hannington left her screaming and hurried on.

Presently the expedition came upon a fire, round which were seated a group of starving people who had come from Taita and were endeavouring to struggle on to the more fertile districts that surround Kilimanjaro. They had already abandoned one woman and child. The mother was dead, but Hannington enabled them to rescue the child by giving them food and encouraging the poor wretches to return and search for the infant, which they found.

The Bishop spent three days at Taveta, in the midst of a magnificent forest, honeycombed with luxuriant gardens of maize, Indian corn, and broad-leaved banana trees. The people were 
peculiarly gentle, and received the expedition in a most friendly manner. In the rainy season, however, the rich, black vegetable soil exudes poisonous vapours. The forest is so dense that it almost excludes the refreshing breezes, and so overshadows the open spaces and plantations that large parts of them are constantly wet.

Hannington had some interesting experiences with Mandara, the chief of the most powerful of the tribes which inhabit Chagga, the highland district on the southern and eastern spurs of Kilimanjaro. Messengers arrived from Mandara with an ox as a present for the king. As the expedition approached Moschi, Mandara's capital, they fired the royal salute which that august monarch exacted from his guests, and were answered by a salvo from his two cannons. When Hannington was ushered into the presence of Mandara, he was impressed, not only by his general appearance, but also by his kindliness of manner and intelligence.

The next morning at dawn Mandara, wearing a rosy-red robe, visited the camp, accompanied by twenty warriors, all stark naked, fine athletic fellows, looking fierce enough to frighten one out of one's wits. Hannington presented the king with a box and a uniform, which he received in a gracious manner.

After breakfast a return visit was paid, and Mandara gave Hannington a goat and a cow. The sum of the royal speech was that Mandara 
wanted guns and gunpowder, and if he could not have them, the next best thing would be a white teacher to live in the land. Mandara maintained his princely bearing and his gentlemanly conduct up to the end of Hannington's relations with him. The only untoward incident was that on one occasion when the king visited Hannington the Bishop was drawing, and drew the king, which rather wounded his majesty's feelings !

Curious and not too pleasant ceremonial marked the visit of Hannington to Fumba's country. When the chief's father arrived in the camp, he brought with him a sheep. Hannington and the old man had to spit on its head and then it was killed. Some strips of skin were cut off and made into rings, one of which was put on Hannington's finger, he in his turn put one on a finger of a member of the other party. After this the liver of the sheep was examined, and finally, says the Bishop, ' we were freely splashed with the entrails, and the ceremony which made us brothers was completed.'

Hannington had a narrow escape from death a few days later in a new territory. He had scarcely aroused himself from sleep one morning when a shrill war-cry rang through the forest, and a large body of armed men sprang from the bushes and bore down upon him. 'Thank God my old nerve remained. I ran forward alone and unarmed to meet them, for the least false step on the part of our men would have caused a general 
massacre. I must confess that my heart seemed to jump into my mouth as they charged up the hill, yelling and brandishing their spears. I seized a bough as a token of peace, and shouted, "Jambo! good-morning! Do you want to kill a white man ?" A sudden halt, and a dead pause; at last, "No, we don't; but we thought you were Masai." ' The Masai were a thieving and murdering tribe who made frequent raids upon the peaceably disposed people of this district. They thought they had cornered a group of them, and meant to massacre the lot.

Hannington considered this journey, to the great mountain and back, as most successful. He had enjoyed excellent health almost the whole way, during a tramp, allowing for the inevitable windings, of more than 500 miles.

On his return to Frere Town the Bishop had the great joy of ordaining the first native ministers of the infant East African Church. They were William Jones and Ishmael Michael Semler, both of them rescued slaves, men who had given proof of sincerity, zeal, and spiritual gifts. He made a second journey to Taita and returned to the coast in record quick time. From Taita he sent forward Wray and the Rev. E. A. Fitch (who had come out from England with Hannington as Bishop's chaplain) to found a station at Moschi, Mandara's capítal in Chagga.

The Bishop had kept in mind, throughout his 
expedition to Kilimanjaro, his ulterior object, namely, the marking out of a new route to Uganda, approaching that country by the north-east, instead of by the south, of the Victoria Nyanza. 'He was overjoyed to think,' writes Mr. Dawson, 'that upon this new route there were no difficulties which might not be overcome by courage, prudence, and experience. No ghastly malarial fevers; no cruel dysenteric attacks, as on the lower road. When he compared his experiences upon this journey with those of his terrible march from Zanzibar to the lake in the previous year, he was filled with a kind of triumph. What if it were possible to push straight through, as Thomson had done, to the north end of the Nyanza ! Might not many lives be saved, and incalculable suffering averted ?'

The only serious difficulty appeared to be the lawless and irrepressible Masai. But others had overcome that; why not he? Yet there was a vital factor in the situation of which even the most experienced were ignorant, a factor which was to seal the fate of the intrepid missionary. What was that? We shall see. 
Chapter IX

\section{THE LAST JOURNEY}

The northern Route to the Victoria Nyanza-The Bishop the only white Man of the Expedition-The most savage Regions of Africa-The dreaded Masai Warriors-Loss of the Medicine Chest-The Bishop's fearless Manner towards hostile Natives-Adventure with a Rhinoceros-The Difficulties of buying Food-A Covenant of Blood-Blinded by BeesThe Masai Warriors-' A very great old Man'-Elephant Steaks-The Bishop leaves the main Caravan-Anxious Days-Report of his Murder.

THE route taken by Bishop Hannington from Frere Town to Usoga, on the north-east of the Victoria Nyanza, is clearly shown in the map which accompanies this volume. Various points of geographical interest would emerge in a detailed, day-by-day narrative of this great expedition, but in this little book we shall pass over these. Our concern is with the human and personal interest of the adventure.

Hannington resolved that he would take no other white man with him on this perilous journey, lying for a great part through the country of a very savage race and involving, in its last portion, the treading of unknown soil. He was anxious that if 


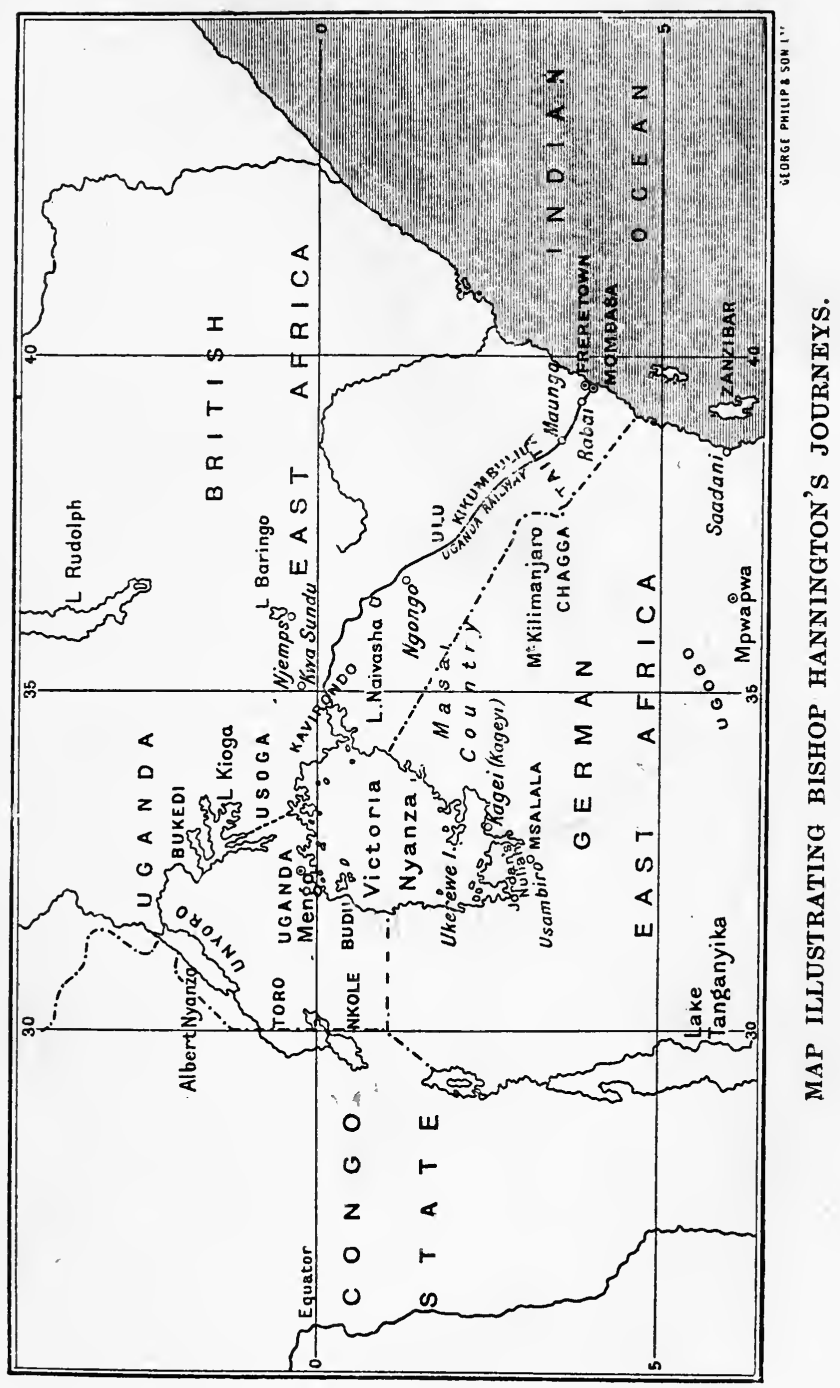



he got into any difficulty or trouble he should not involve any of his friends in the result. 'My feeling is that I would rather be alone,' he writes to his wife, ' as the anxiety is rather increased than otherwise by another man, however good he may be. I feel this-that another man could add nothing to my safety.'

The Bishop led the way out of Rabai on Thursday, July 23, 1885, at the head of a caravan 200 strong. Two days later Hannington wrote to the C.M.S. Committee that he believed the God of Love was going to give him a time of rest and peace and a slight cessation from toil. 'While the Committee is in Scotland, in Switzerland, or, it may be, eating shrimps at Margate, I shall be taking things easily in some of the savagest regions of Africa.'

There had been considerable difficulty in hiring the porters, because of the dread which was entertained of the Masai warriors, through whose country the route lay. The terror of these truculent young blood-shedders and cattle-lifters 'lay like a nightmare upon the minds of their own countrymen.' Hannington was always both firm and considerate towards the members of his caravan; they had the utmost confidence in his kindness and justice, and he had also wonderful success in dealing with the tribes, not always disposed to be friendly, encountered on the march.

The haunting fear of the Bishop through the 
expedition was the want of food. The country had suffered from a famine and was not yet far on the road to recovery. The apprehension of starvation finds expression again and again in his letters and diary. 'If,' he writes, 'I had been permitted to start with fifty men less I should have been more sanguine. But if this is God's time for opening up this road, we shall open it up.'

Hannington's cheerfulness and philosophy never failed him under the multitude of vexations and mishaps which must always mark an enterprise of this sort. At a certain point his watch went wrong, the candles and lamp-oil were forgotten and left behind, his donkey died, and so he was compelled to walk every step of the way. 'Well,' says the Bishop by way of comment, 'having no watch, I don't wake up in the night to see if it is time to get up, but wait till daylight dawns. Having no candle, I don't read at night, which never suits me. Having no donkey, I can judge better as to distances, and as to what the men can do.'

The Rev. William Jones, a native clergyman who accompanied the Bishop as far as Kwa Sundu and took out of his hands many of the lesser worries and responsibilities of the management, kept a journal of the expedition. Further, Hannington's own tiny pocket diary, with its daily jottings, was recovered by a Christian lad at Rubaga, who bought it from one of the band that murdered him. From these sources, the Rev. E. C. Dawson, M.A., makes 
liberal extracts, and from these extracts we have compiled our own narrative.

The Bishop, as we have already pointed out, had a rare power of winning the hearts of those with whom he had to do, European or native. When the caravan was leaving Taita, one of the WaZaramo boys who had been engaged to carry food for the caravan, and who were all paid off and discharged near Taita, insisted that he would follow the Bishop. No arguments availed. 'Whither thou goest I will go,' and finally the poor lad was taken.

A serious mishap befell the expedition within three weeks of its starting. One day the boy who bore the medicine chest was nowhere to be found. The Bishop would not believe that the boy had run away, nor did it seem probable that he would do so in a region remote from the coast. In the early days of an expedition the danger of desertions is very great, because many of the porters enlist merely for the sake of the advance wages which they get before the start, intending to give the caravan the slip at the first favourable opportunity. When they have got some distance into the interior, it is more difficult to retreat than to advance, and accordingly they then go on peaceably enough. However, the medicine boy was gone, and it was hardly safe to go on without the chest he had been carrying. The Bishop offered a handsome reward for the finding of the boy, and detached ten men 
to search for him. It was all in vain. Yet on they went into the perilous unknown.

Hannington showed both justice and fearlessness in his dealings with the natives with whom he came in contact. They were frequently troublesome and made exorbitant demands for tribute. What was offered them they would scornfully accept and ask for more. On one occasion, being more than usually exasperated, the Bishop ordered the tribute that had been already given to them to be taken away, and calmly walked off to his tent. The elders of the people were confounded, not being accustomed to be treated otherwise than with humble deference by passing caravans. When, however, they saw that the white man was in earnest, they called for the interpreter and begged that his master would not be angry, but would let them have the original gift.

/ The way of the caravan, on another occasion, was blocked by a mob of armed men, demanding gifts and threatening, if these were not forthcoming, to fight. On the expedition moved, however, menaced on every side by the infuriated mob. The interpreter counselled submission to their demands, in order to avert the massacre of the whole caravan, and we are told that the native who bore the Union Jack trembled fearfully. Presently Hannington appeared. At the sight of him, says Mr. Jones, the barbarians gave way like a cloud before the wind. 'They were all amazed to see the Bishop, 
for many of them had never seen a white man in their life. They stood thunderstruck and gazing at him. The Bishop made his way through the crowd. Then many of them resisted him with all their might, but he walked rapidly on, quite regardless of their yellings and ferocious cries. Twice they barred our way with a human fence, and twice we passed through them to their great astonishment. The Bishop all this time was quite calm, and only smiled at all their gestures and menaces. At last we came to a stream which divided one district from another. They refused to let us pass, but the Bishop went straight ahead, and was followed by all the caravan.' Later in the day the same men who had showed themselves so truculent came to the camp, in a quite peaceful attitude and frame of mind, to barter and dispose of their goods.

The Bishop and Jones one day sighted a rhinoceros, and, as the caravan wanted meat, they tried to stalk him. They succeeded-says Mr. Dawson, who tells the story-in creeping within twenty yards of the monster, who happened to have keen scent but short sight. Then he spied his enemies. Down they both dropped upon the grass.

'Fire, my lord !' said Jones.

'No,' replied the Bishop; ' as he stands I cannot get a good shot ; wait.'

It is not pleasant to kneel face to face with a rhinoceros in an open plain, with the knowledge that if the brute makes out your whereabouts 
he will come thundering down upon you like an express locomotive.

Jones got nervous. 'Fire, my lord!' he whispered anxiously.

But the Bishop would not, and the two remained in their uneasy position, like two devotees of Siva, with their knees bent before the grim idol. At last the great beast dashed round with a snort. The Bishop leaped to his feet and fired, but failed to stop it, and after a short chase had to return without his rhinoceros steaks. The hungry camp was bitterly disappointed.

A few days later the Bishop had a narrow escape from another rhinoceros, which almost charged him home. A shot in the head produced no effect, and the second shot, which turned him, was delivered point-blank at four yards' distance.

The extraordinary difficulty of procuring food from the natives is well illustrated in the account of Hannington's dealings with the Wa-Kikuyu, a tribe which had suffered severely from the Swahili slave-traders, and was in consequence both very timid and very vindictive towards all the caravans that proceeded through their country.

The Bishop was anxious to hold some intercourse with the Wa-Kikuyu, but they dared not venture down to his camp. He therefore went to them with an escort of only ten men, but they fled before him. Hannington's men were without food, and the camp resounded with their wails, 'Let us go 
back,' some cried. Others asked, 'Is this our last place? Have we been brought here to die ?' It was with the very greatest difficulty that the Bishop purchased a few sweet potatoes from the Wa-Kikuyu, and thus for the moment averted disaster.

Early next morning Jones started off with twenty men, to see if they could do business with the Wa-Kikuyu. As payment for their intended purchases, they took a few strings of beads, some cloth, and iron wire. They crossed a stream, made a fire upon a rock and sat down, having fired guns as a salute and to announce their presence, though they could see no one through the impenetrable undergrowth. After waiting two hours a man came out from the forest, with fresh leaves in his hand, as a mark of peace. Jones and his men plucked leaves and waved them. Then the timid savage drew near, with a message from his chief, desiring to know whether Jones had come to fight or to buy grain. When he got his answer he flew back to his friends and was lost to view.

Three men next stepped out of the wood, said that the chief was coming, and disappeared.

Then the chief arrived, a man of about fifty, half-drunk, and reeling. He spat copiously on his hand and shook hands with Jones, who said that he desired to 'eat muma' with him. To 'eat muma' is a ceremony by which friendship is 
supposed to be sealed. Blood is extracted from the arms of both parties to the contract, and a piece of meat dipped in the mingled blood is eaten by each. The two then are accounted 'brothers.' The chief refused to 'eat muma' with Jones, but clamoured for the presents he had brought; he promised that after receiving them his people would bring food for sale.

Off the savages went with their gifts, and a quarter of an hour later buying and selling began. Trade had scarcely become brisk when the WaKikuyu showed signs of hostility. From a distance they brandished their swords and threw poisoned arrows in the direction of Jones, who quietly gave orders to his men to hold their guns in readiness. The Wa-Kikuyu made the women who were selling turn back. The children all fled. Only the men remained, yelling and throwing arrows. Jones and his escort, without firing a shot, retired slowly into the jungle with the food they had bought, keeping their faces towards the enemy.

But the expedition in its desperate straits could not afford to allow itself to be discouraged. The Bishop wanted to face the Wa-Kikuyu, armed with his umbrella, but his followers dissuaded him from this course. Next day, however, a hundred men left his camp in order to buy food. This time the Wa-Kikuyu came down in great numbers, and there seemed a good chance of doing business. But some of Hannington's men attempted to 
steal, there was a sciffle, one man received two sword cuts on his thigh and another had his skull fractured with a club. Business was again interrupted.

The Bishop now took a hand in the matter personally. With a hundred men he sought to reopen negotiations with these tiresome Wa-Kikuyu. All went well for a little, but presently one of Hannington's headmen saw a man making off with his upper garment and ran after him, firing a charge without a bullet to stop him. Immediately the market broke up and the Wa-Kikuyu fled in all directions into the jungle. But the Bishop, seeing what would follow if the men were allowed to do what they pleased, ran and stood where the natives had piled their saleable things, and prevented any of his men from snatching them. He then ordered the men to march to their camp and leave him alone.

Presently a native peered out of the thicket, and when the Bishop beckoned to him drew near, and Hannington gave all the goods belonging to his people into his hands and then returned to camp, very angry with his men. The man who fired at the native had his gun taken from him and was severely reprimanded.

The Bishop went out again next day with seventy men. This time he determined to purchase everything himself. When the natives came down, Hannington concentrated his men on one spot, 
from which he forbade them to move. Things went for a while very smoothly, till suddenly the cry of 'Masai' was raised and a number of warriors leapt from the jungle with spears and shields. It was a false alarm, but the Wa-Kikuyu took fright, and again the market was stopped.

The Bishop returned weary and disgusted. The men were daily growing weaker and weaker and it would soon be impossible to move either forward or backward.

A more successful attempt to purchase food was made a few days later. Hannington again went out with about one hundred men whom he caused to sit in a circle while he dealt with the Wa-Kikuyu, with whom the plain was crowded and who crept in on every side. The Bishop's men were in considerable apprehension, and each of them had his loaded gun by his side. When the natives had completed their sales, they assumed a defiant attitude and raised their war-cry. The women fled. Hannington ran to the front and waved some grass in token of peace, and for a time order was restored. Looking round, however, he saw a group of men close behind him, with their bows bent, and on the point of shooting. When they caught his eye, they retreated.

At last, after a fortnight's delay, the Bishop had purchased enough food to justify him in making a move forward, and he was done with these exasperating Wa-Kikuyu. The whole incident is 
a good illustration of the patience, scrupulous justice, and cool courage which Hannington showed in his dealings with natives.

A few days later, when the caravan was in motion, a host of the Wa-Kikuyu made an attack upon the sick who were being carried in the rear. The men in charge of the patients fled, but, wonderful to relate, the invalids suddenly revived and also took to their heels, escaping with a few blows from clubs. The Bishop and some of his men, arriving on the scene, put the assailants to flight with a single volley.

A new enemy in the shape of a swarm of bees, numbering thousands, now assailed the caravan. The insects covered the ground for some 200 yards in every direction from the tree whence they had descended. The men ran for their lives, many of them dropping their loads. Some of them actually cried like children and called upon their mothers. The Bishop was driven back in an attempt to reach the deserted loads. Draping himself in his mosquito curtains he tried again and succeeded, but not without being stung most pitifully. Jones was almost totally blind for two days as the result of his injuries.

The dreaded Masai warriors were encountered by the caravan a day or two later. The young braves surrounded the Bishop and his men, but did not seem to design mischief. The women came into the camp and sold things. It appears 
that the term of service of the Masai warrior lasts from his youth until he is about thirty, when he marries. He makes a good fighting man; living on nothing but flesh and milk, his body is strong and healthy. $\mathrm{He}$ adds to the fearsomeness of his appearance by smearing himself with oil and red earth. In his warrior days he is idle, cruel, and haughty, holding all other natives, and particularly the coast porters, in contempt, and very exacting in his demands for tribute. When he marries he lays down his spear, and with it lays aside his fierceness and settles down to a peaceable life, showing himself remarkably kind to strangers

- and especially to women.

The Bishop's troubles with the Masai were comparatively slight. They were very hard to satisfy in the matter of tribute, and, after being liberally treated, took to wholesale pilfering. They tore open the loads and turned over the boxes, Hannington's men not daring to interfere lest they might provoke a massacre. The Masai were everywhere, filling the Bishop's chair, cot, washtub, bags, and biscuit-boxes. Jones perceiving a load of wire being borne away by a group of young warriors, gave chase, flung himself into their midst and dashed the load to the ground without regarding their threatening spears. They were greatly astonished and then gave way, and Jones carried the load back in triumph to the camp. One of Hannington's men got his head 
cut open with a spear-thrust; another had his clothes stolen, but Jones compelled the culprit to make restitution. The Masai insisted upon seeing how the members of the caravan ate. They touched and befouled everything with their filthy fingers.

The Bishop personally was fortunate enough to gain the admiration of the Masai. They examined him closely, stroked his hair and smoothed his beard. Then stepping back to get a good view of his figure, they murmured, 'Lumuruo Kitó!' which, being interpreted, signifies, 'A very great old man!' As a matter of fact, Hannington was only thirty-seven at the time, but sufferings and privations may have aged him in appearance, though they had certainly not robbed his heart of its youth. In his familiar correspondence he would sometimes in fun refer to himself as old, and his drawings of himself in various predicaments, mostly amusing, invariably represent him as much older than he was or could have appeared. Three Masai brought the Bishop an ox for sale. With these he made great friends, allowing them to pass the night in his tent. He writes that, 'Having strewed the floor with the leaves of the sweet-scented Caleshwa, we laid us down, their spears and shields at their sides. They packed themselves away like sardines in a box, and I covered them over, first with a leopard's skin, then with a grass mat, and finally with a waterproof sheet. They fell almost immediately into a most gentle sleep.' 
Mr. Dawison aptly compares living among the Masai with 'moving among a troop of lithe and beautiful, but half-tamed leopards. The traveller has to be ever on the alert, or he will be pinned by the throat.' As vividly suggesting the perils

$\therefore$ from which Hannington had escaped, we may mention that on the morrow of leaving the Masai he encamped at a place where some years before a caravan of Iooo men was surrounded and cut to pieces by these ferocious warriors.

One day while the Bishop was preparing to settle with a cow elephant which was charging down upon him, two rhinoceroses whom he did not see, proceeding, as they were, from another direction, also made straight for the valiant hunter. Just as the cow elephant was getting home, the rhinoceroses got in between. Thereupon the elephant turned her attention to them. And so this great sight was witnessed: the Bishop volleying the elephant, the elephant chasing the rhinoceroses, and the caravan men dashing down their loads and scattering in every direction before the great beasts. However, the Bishop brought down his elephant, and the people shouted for joy. The men scrambled forward with their knives, and in a few minutes the huge beast was cut in pieces. Some of the men ate the flesh raw, while others made large fires and sat round to enjoy their feast.

Every now and then we come upon tender, touching, wistful passages in the Bishop's record 


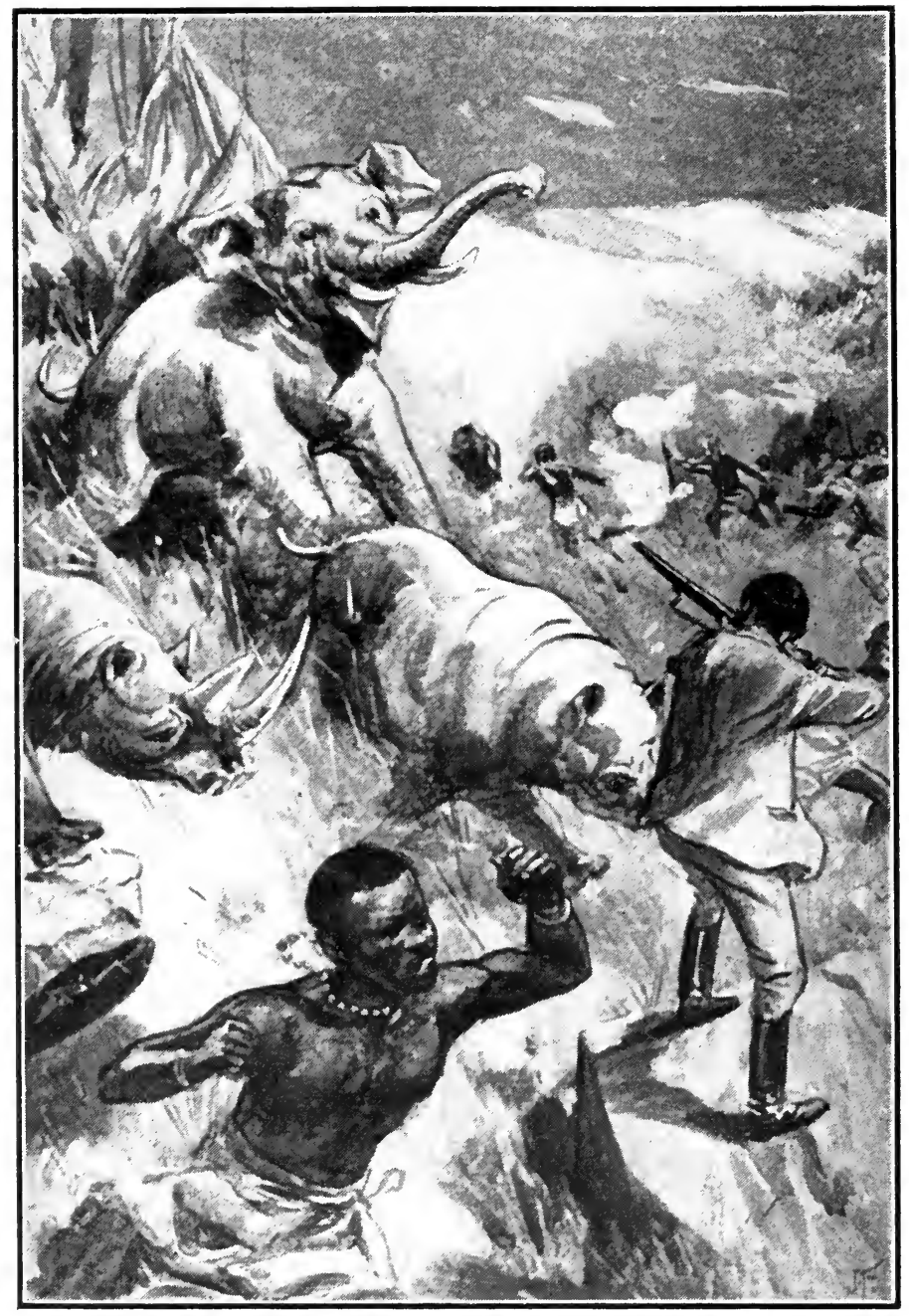

THE BISHOP VOLLEYING THE ELEPHANT, AND THE ELEPHANT CHASING THE RHINOCEROSES. [See page 152.] 

of his experiences. 'We had our two pleasant services '- - he is writing about a Sunday - ' and the day passed in the most absolute rest and peace. I lay stretched on my back in quiet contemplation and sweet dreams of dear ones at home, and often longing, often wondering whether I shall be permitted to see them.' He never saw them again. In spite of doubts and fears he pressed on doggedly, often very fatigued. 'As a sign how tired one can be,' he wrote, ' on Friday last, when going to bed, I took a bite from a biscuit, and fell asleep with the first mouthful still in my mouth, and the rest in my hand.'

And now we approach the crisis of this great adventure for the cause of Christ. The caravan had now reached Kwa Sundu. The Bishop here decided that he would proceed to the Victoria Nyanza alone, leaving Jones behind in charge of the caravan. He selected from the 200 fifty porters to accompany him. Did he reach Uganda, and find that any of the missionaries wished to return, he intended that they should take the new route by Kavirondo, leading back Jones and the caravan with them. For himself, having done all that seemed necessary and desirable in Uganda, he would visit the churches which were established to the south of the lake, and return to the coast by the old Unyamwezi route.

Accordingly, the Bishop and his faithful native chaplain parted-for ever, as it was decreed-on 
October I2, I885. Hannington was not at all well, an abscess in his leg gave him considerable pain, but he would not be held back. Thirteen days pass, there is no news from the Bishop, and Jones begins to get very anxious about his friend's safety and that of the caravan under his own charge. 'If the Bishop does not come this way,' he writes in his journal, 'I shall have to return by the same way that we came. Wherever we passed our caravan was laughed at, owing to our small numbers What will they say when they see us still less in returning ?' On October 30 a rumour reached Jones that Hannington had been attacked by a neighbouring tribe, but nothing was said about the Bishop's personal safety. Jones thought he had reason for disregarding this report as utterly false. However, at noon on Sunday, November 8, Bedue, one of the men, came to Jones, sighing and breathing hard.

'What's the matter ?' said Jones to Bedue.

'Two men have come to me,' said Bedue, ' with the report that the Bishop and his party have been killed !'

'Where are they? Bring them to me at once that I may learn the truth of their story,' replied Jones. The two men presented themselves. They said that they had picked up three of Hannington's men, who had managed to escape when the Bishop and his men were being killed. They had not themselves witnessed the massacre nor seen the 
dead bodies. As the three men who were alleged to have escaped had not made their appearance, Jones persuaded himself that his two informants were deceiving him. They said that if Jones would give them presents they would fetch the three men, but he refused their offer and gave them nothing. At the same time he was full of trepidation.

Presently one of the three refugees arrived in camp, stripped of everything. He reported that the Bishop and his party had been seized on the confines of Uganda, imprisoned for nine days, and then slain one by one. Before he had finished his tale the two remaining men arrived. One of them had been speared in the right arm. All three agreed that the Bishop was dead, but as to the manner of his death there were discrepancies in the narratives. One said that the Bishop was speared and his Portuguese cook shot. The other two said that the Bishop was shot with two guns and the Portuguese cook with one. Jones could get no satisfactory reply from these three men as to how they had managed to escape. Accordingly he gave out that the report was false, that these men had wickedly deserted the Bishop, and instructed all the members of the caravan to represent to the people of the village that the rumour was lying.

But he could not help asking himself, in great distress of mind, "Can it be true that the Bishop is killed ?' 


\section{Chapter X}

\section{WHAT HAD HAPPENED IN UGANDA ${ }^{1}$}

The first Administration of the Lord's Supper in UgandaDeath of King Mtesa-King Mwanga disquieted by the German Annexations-' The Back-Door of Uganda 'Persecution of native Christians-Mwanga sends Messengers to order the seizure of the Bishop-Rumours of his Murder reach the Missionaries in Uganda.

UR very brief summary of the wonderful story of Uganda, given in a previous chapter, had brought us to the point when the missionaries were beginning to reap fruit from their labours, when they had baptized their first converts. We ought to add here, before proceeding further, that only one member of Hannington's first expedition attained his goal at that time-the Rev. R. P. Ashe, B.A., reached Uganda. At a later period Gordon also had the joy of working among the Baganda.

We have mentioned that Hannington, in his first expedition, took out with him a boat with

1 The materials for this chapter are derived from the two excellent and indispensable works acknowledged at the beginning of Chapter IV. in this little book. 
which to navigate the Victoria Nyanza. Alexander Mackay came over from Uganda to the south side of the lake in order to put the pieces together, and the little craft was launched at the end of 1883. Mackay gave it the name of 'Mirembe,' meaning 'peace.' He made several voyages in 'Mirembe,' and in his narrative of one of them he dwells on the joy of having with him nine Christian boys whose singing of hymns in the night, as they rowed, was a great cheer.

Mackay, O'Flaherty, and Ashe were in Uganda together for more than two years and a half; Mackay engaged with works innumerable, O'Flaherty busy with translations of Scripture, and Ashe teaching the boys. Mtesa continued as capricious as ever, and the Arabs as hostile as ever, but during the greater part of the time the Jesuits were away. Between March I882 and November I884 eighty-four persons were baptized, all of them after careful instruction and testing; and on October 28, I883, for the first time the Lord's Supper was administered to twenty-one converts.

'It soon became fashionable,' writes Mr. Dawson, 'to learn to read. The store-houses and offices of the Court were literally converted into readingrooms. Lads might be seen everywhere, sitting in groups, or sprawling on the hay-covered floor, all reading-some the Book of Commandments, some the Church prayers, others the Kiswahili 


\section{I58 WHAT HAD HAPPENED IN UGANDA}

New Testament. Nor were the books and papers given to them for nothing. They were both ready and eager to buy whatever literature they could get.' Among the converts was one of Mtesa's own daughters.

King Mtesa died on October Io, I884. He had often talked of becoming a Christian. More than once he had asked for baptism, for he knew that the message brought to him was true. But he would not give up his sins, and so died outside the pale of the Church of Christ. Mackay had frequently addressed to the king the most earnest and passionate appeals. 'You have the New Testament; read there for yourself. God will judge you by that. There never was anyone yet who looked for the truth there and did not find it.' But Mtesa had remained obdurate.

At his death, if custom had been followed, all his sons except the one chosen to succeed him would have been slain, and probably there would have been also a general massacre in which all foreigners in the country would have fallen victims. But the work of the missionaries had wrought a great change in the spirit of the people, their ideas of right and wrong had been clarified and strengthened, and accordingly, though the whole country went into mourning, no one was put to death.

Mwanga, the new king, was a youth of eighteen. $\mathrm{He}$ had received instruction from the C.M.S. 
missionaries, and also from the Roman Catholic priests, but little impression had been made upon his heart. His father, with all his caprice, perversity, and vice, had possessed a considerable measure of enlightenment; Mwanga had all his father's defects and, as far as could be discerned, a very small share of his redeeming qualities. $\mathrm{He}$ was dowered with more than a proportionate quantity of the dominating vice of Africans-namely, greed. He requested Mackay to go across the lake and bring up some more white men-the idea being to exact valuable presents from these. Mackay went, but returned without white men. The unfriendly chiefs at Court suggested that he had never intended to bring back white men, but had used the opportunity to communicate with Mwanga's enemies. Then Mwanga bethought him to invite the French priests to return to his country.

Mwanga's fear and hatred of Europeans sprung from intelligible causes. The news of the German annexations, though these were carried out far distant from Uganda, had reached his ears; he was fully persuaded that the white man would come and eat up his country, and the Arabs about his Court, for obvious reasons, encouraged him in that belief. 'Alarm was at its height,' wrote Mackay, 'the Court counselled killing all the missionaries, as we were only the forerunners of invasion.'

A recent happening had given colour to this 


\section{I6O WHAT HAD HAPPENED IN UGANDA}

suspicion. Mr. Joseph Thomson had just made his memorable journey from Mombasa to the north side of Victoria Nyanza. It is true that he did not quite reach Uganda, but he had got near enough to alarm the king of that country; his journey showed the practicability of the route, and mapped it out for those who should follow. This proceeding was very disquieting to Mwanga. The people of Uganda regarded the Victoria Nyanza as their natural frontier, and deeply resented and suspected attempts to reach them in any other way. The alarm was raised that Uganda might be entered by the back-door, as it was called.

A cruel persecution now began. No attempt was made to molest the Europeans, but it was sought to isolate them, to render their past work fruitless, and bring their present operations to a standstill. The natives who showed themselves favourable to the Christian teachers, or received their instruction, were very severely handled. Three of the Court pages were, on January 3I, I885, put to death-cut about cruelly with long, curved knives, and then thrown on to a large fire.

As ever, the blood of the martyrs was the seed of the Church. Many of the people became eager for baptism and received it. One of the executioners was so impressed by the behaviour of the pages under torture of knife and fire that he came to learn to pray. The native Christians were not daunted, although Mwanga threatened to burn 
alive any who frequented the mission premises. On July 26 there was a congregation of $\mathrm{I} 73$ souls, and thirty-five partook of the Communion. A Church Council was formed, consisting of the leading members among the native Christians, to act in case the missionaries should be suddenly expelled or obliged to withdraw. Mackay went on, in perfect calmness of mind and undiminished vigour, with the work of translating and printing. The translations were actually revised by the native converts, in order to get as near to absolute accuracy as possible.

Meanwhile rumours had reached Uganda that white men were approaching the country from the north end of the Victoria Nyanza. The missionaries, knowing the incensed feelings of Mwanga towards Europeans, and the rooted objection to entrance into the country by ' the back-door,' were greatly alarmed. Mackay was charged with sending his friends to Busoga, there to collect an army, while he stole away the hearts of the people in Uganda from their king. When they heard that the leader of the expedition was a tall, middle-aged man who had lost a thumb, they trembled, for they recognised Hannington. They constantly sought interviews with Mwanga to induce him to allow them to meet him and conduct him themselves to the capital; but their petitions were unavailing. They heard that the king had ordered the Bishop to be seized, and they waited in sickening suspense for the issue. 
Mackay wrote in his journal on October 30 : ' After dark, Ismail came to tell us that messengers had returned from Busoga with the tidings that the white men had been killed, with all their porters.'

Was this true? And if it was, how had it come to pass?

Hannington knew that Mtesa was dead, but of what else had transpired in Uganda he knew nothing. Very probably it had never entered his head that the news of the German annexations was known in that country, or, if known, would excite any alarm so very far in the interior. But the factor of which he and all the experts were ignorant, yet the factor which sealed his doom, was the ineradicable objection of the people of Uganda to any entrance of their country from the north-east. The danger which had been foreseen, the hostility of the savage Masai warriors, had been overcome; the unseen and unknown danger was to prove fatal. 


\section{Chapter XI}

\section{THE MARTYRDOM OF BISHOP HANNINGTON}

Laughing away Obstruction-Encamping between two War Parties-Held a Prisoner-Harsh treatment-Tortured by Fever and Anxiety-Deceived by hopes of Liberty-Led forth to Execution-The Bishop's majesty in the presence of his Murderers-' I die for the People of Uganda'-The blue Pennon-A sad Procession-A noble Martyr.

$W^{\mathrm{E} \text { now resume the narrative of the Bishop's }}$ adventure after he left Jones and the bulk of the caravan behind at Kwa Sundu on

October I2.

Within a week Hannington had walked about I70 miles. The lake suddenly burst upon his view long before he expected to see it. The people through whose country he traversed were friendly, but each petty chief wished him to stay with him for a day or two, and Hannington was all impatience to get on. This pertinacity sometimes excited feelings of hostility, and threats of violence were not wanting. His own men were terrified, but Hannington merely laughed away obstruction, and on October I7 he found himself on the shore of 
the lake. 'We are in the midst of awful swamps,' he wrote in his journal, so wonderfully recovered after the catastrophe, ' and mosquitoes as savage as bees.' He had a strange foreboding of disaster in spite of the fact that everything, so far, had gone well. The nearer he got to his goal the more anxious he seemed to be about arriving. When he expressed this feeling he was within a fortnight of his death.

He was now in Usoga. He fell in with a mob of warriors from Uganda, many of whom were drunk and in a dangerous mood, coming round him, shouting and yelling, and ordering him about. However, he opposed them merely by sticking his fist in the faces of the most noisy, and pushing through the mob. He encamped between two war-parties, having both within earshot, and finding his men very difficult to manage on account of their terror.

The Bishop came face to face with Lubwa, the ruler of Usoga and a vassal of King Mwanga, on October 2I. In an insolent tone the savage chieftain demanded ten guns and three barrels of powder. Hannington of course refused. He was requested to remain three days, and again refused. Then the war-drums beat, and he was surrounded by more than Iooo soldiers. At last Hannington consented to stay one day. A soldier was placed to guard him in his tent, and follow him if he moved away from it. $\mathrm{He}$ climbed a neighbouring hill 


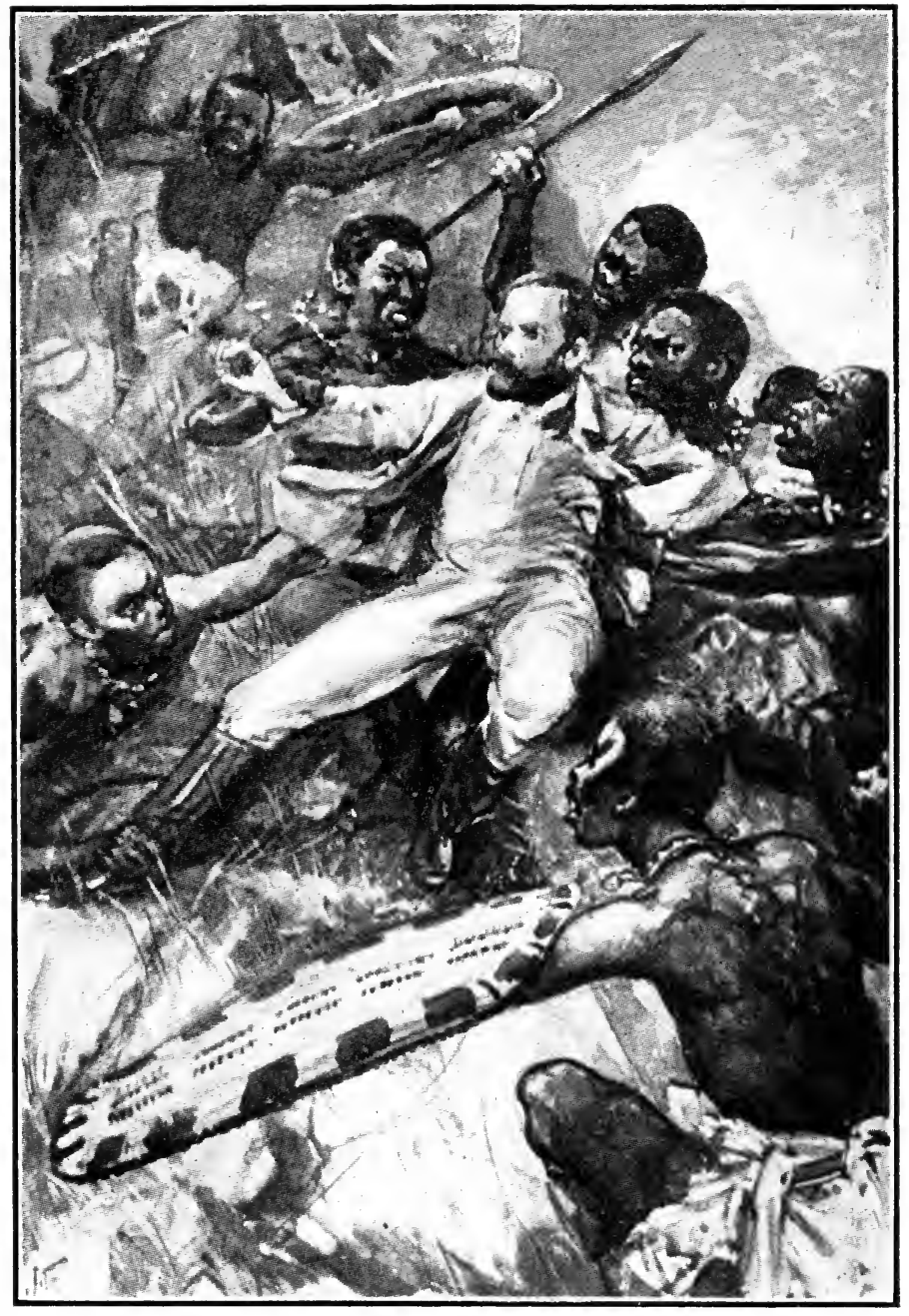

THEY FORCED ME UP AND HURRIED ME AWAY. [See page 165.] 

and got a splendid view of the Nile, issuing out of the great lake, half an hour's distance away. But he was refused permission to visit it.

What followed is best told in the Bishop's own words : ' I asked my headman, Brahim, to come with me to the point close at hand whence I had seen the Nile, as our men had begun to doubt its existence; several followed up, and one, pretending to show me another view, led me farther away, when suddenly all twenty ruffians set upon us. They violently threw me to the ground, and proceeded to strip me of all valuables. Thinking they were robbers, I shouted for help, when they forced me up and hurried me away, as I thought to throw me down a precipice close at hand. I shouted again, in spite of one threatening to kill me with a club. Twice I nearly broke away from them, and then grew faint with struggling, and was dragged by the legs over the ground. I said, " Lord, I put myself in Thy hands, I look to Thee alone." Then another struggle, and I got to my feet, and was thus dashed along. More than once I was violently brought into contact with banana trees, some trying in their haste to force me one way, others the other, and the exertion and struggling strained me in the most agonising manner. In spite of all, and feeling I was being dragged away to be murdered at a distance, I sang " Safe in the arms of Jesus," and then laughed at the very agony of my situation. My clothes 
torn to pieces so that I was exposed; wet through with being dragged along the ground; strained in every limb, and for a whole hour expecting instant death, hurried along, dragged, pushed, at about five miles an hour, until we came to a hut, into the court of which I was forced. Now, I thought, I am to be murdered. As they released one hand, I drew my finger across my throat, and understood them to say decidedly, No.'

Hannington was informed that he had been seized by order of Lubwa, and that he was to be kept prisoner until the pleasure of Mwanga should be known. Meanwhile he was tormented with dismal apprehensions concerning the fate of his men. Were they all murdered? After two or three hours of suspense, during which he remained bound and shivering with cold, Hannington was relieved by the arrival of his Portuguese cook and a boy, with his bed and bedding. The men, like their leader, were likewise robbed, seized, and detained as prisoners.

The hut in which the Bishop was confined was warmed by a fire on the hearth, but there was no chimney and no ventilation. Rats and other vermin swarmed, and the floor was covered with rotting banana peel and leaves and filth. He was in great pain, and consumed with thirst. It was so dark that he could scarcely see to read or write, and the prisoner was so weak that he could scarcely hold up his small Bible. About twenty men 
shared this wretched hovel with him. Towards evening he was allowed to sit outside for a little time and enjoy the fresh air ; but when he returned his prison only seemed the more unbearable to him, and, broken down in health and nerves, he burst into tears. Though he was so feeble the savages guarded him as if he were a giant in full vigour.

During the evening of October 22-23 loud yells and war-cries arose outside the fence which surrounded the prison-hut, and Hannington fully expected to be murdered. But he simply turned over and said, 'Let the Lord do as He sees fit; I shall not make the slightest resistance.'

During the day the Bishop was summoned by his guards to come outside his prison. When he emerged he was face to face with Lubwa, with about 100 of his wives, who had come to feast their eyes on him in cruel curiosity. Hannington confesses that he felt inclined to spring at the savage chieftain's throat, but restrained himself, and refreshed himself by reading, 'Love your enemies, bless them that curse you, do good to them that hate you, and pray for them which despitefully use you, and persecute you; that ye may be the children of your Father which is in heaven : for He maketh His sun to rise on the evil and on the good, and sendeth rain on the just and on the unjust' (Matt. v. 44, 45).

Lubwa agreed to allow the Bishop to sleep in his own tent, with two armed soldiers at each 
door. After a good night's rest Hannington found himself able to say that he forgave the old scoundrel and his agents for their rough treatment of him, although he could only move with the greatest discomfort and ached as though he had rheumatic fever. But, with his usual soundness of judgment, he came to the conclusion that, in the interests of other travellers in that region, the outrage could not be overlooked.

His sense of humour did not desert him even in this most perilous extremity. He says that his guards became very careless, and that he might in a few days be able to escape. In this hope he was doubtless quite mistaken, for Mwanga had resolved to remove him by death; but it is characteristic of Hannington that he should add, 'I should be the more inclined to stop should they say Go, to be a thorn in the old gentleman's [Lubwa's] side, and I fear from an inborn feeling of contrariness. I send him affectionate greetings and reports on my health by his messengers twice a day.'

Hannington and his guards became very good friends. Their relations were almost affectionate.

Three detachments of the chief's wives-he was believed to have 1000 in all-came to see the distinguished white prisoner. They were, on this second occasion, quiet, well-behaved, and greatly amused. Two of his men came daily backwards and forwards to bring him food. This duty was allotted in turns, and there was great 
competition each day among these devoted souls as to who should perform that office for their brave and greatly admired leader.

Signs of fever crept over Hannington during his fifth day in prison. $\mathrm{He}$ was still without suspicion of the fate that was in store for him. $\mathrm{He}$ was hourly expecting the arrival of a message from Mwanga, saying that he might advance. Thirty-three more of the chief's wives came to amuse themselves by gazing at the prisoner. For the first time since leaving the coast he was unable to eat his food. His health and spirits were rapidly sinking. He feared that Uganda was going to be forbidden ground to him-forbidden by disease, not by spear-thrust or musket-shot. The next day 'only a few ladies came to see the wild beast. I felt so low and wretched that I retired within my den, whither they, some of them, followed me; but as it was too dark to see me, and I refused to speak, they soon left.'

Word came on October 28 that Mwanga had sent three soldiers, but with what purpose they had come, or what news they had brought, Hannington did not know. He had passed a terrible night with a noisy, drunken guard, and with the vermin swarming in his tent. Fever was fast developing. ' $O$ Lord, do have mercy upon me and release me,' he cried. 'I am quite broken down and brought low.'

He records, under date October 29, I885, that 


\section{I7O MARTYRDOM OF BISHOP HANNINGTON}

- a hyena howled near me last night, smelling a sick man, but I hope it is not to have me yet.' That same day he was murdered.

The manner of the end was in this wise: On Wednesday the 28th, says Mr. Dawson, there had been much drumming and shouting among the natives. When Hannington's men asked the meaning of the demonstration they were told that Mwanga had sent word that the European should be allowed to proceed to Uganda. Mr. Dawson

* very reasonably conjectures that the same story was told to the Bishop on the following day as an excuse for hurrying him out of his prison-out to the place of execution. When, therefore, he was conducted to an open space without the village, and found himself surrounded once more by his own men, he was no doubt full of joy, thinking that the worst was over and that he was now going to enter on the last stage of his journey to Uganda.

But in a moment he was undeceived. With a wild shout Lubwa's savage warriors fell upon Hannington's disarmed and helpless caravan-men and their flashing spears soon covered the ground with the dead and dying. As the natives told off to murder the Bishop closed round him, pausing for a moment with their poised weapons, Hannington drew himself up in that majestic manner which, when he employed it, was so impressive, and bade them tell the king that he was about to die for the people of Uganda, and that he had purchased the 
road to their country with his life. Then as they still hesitated he pointed to his own gun, which one of them discharged, and Hannington fell dead. His last words to his friends in England-words scribbled by the light of some camp-fire-were : 'If this is the last chapter of my earthly history, then the next will be the first page of the heavenlyno blots and smudges, no incoherence, but sweet converse in the presence of the Lamb !'

Bishop Hannington met a martyr's death, as we have seen, on October 29, I885. On the following New Year's Day letters reached Zanzibar from Uganda by the old route, announcing that Mwanga had ordered the Bishop to be killed with all his followers; and the telegraph passed on the news to London that afternoon. From Zanzibar the news also reached Frere Town and Rabai, and threw the poor women there, whose husbands had gone with Hannington, into dire distress. Apparently the entire caravan of some 220 men had perished.

But this was not so. Only fifty men had accompanied the Bishop from Kwa Sundu into Usoga, and of these four had escaped and carried the tidings of the massacre to Jones. He had not given full credence to their narratives, because of the discrepancies in them. He waited on for over a month, hoping against hope, but at last became fully convinced that the worst had happened. To 
have penetrated into Usoga would have meant certain death for the whole caravan, and so Jones made up his mind to go back to the coast by the route they had already traversed. We must be allowed to quote Mr. Dawson's touching and beautiful account of the return of the caravan.

' On the 4th of February I886, at sunrise, the Christians at Rabai were wending their way to the early service when they were startled by the sound of guns; and presently some messengers-weary men, and with the marks of long travel upon them - came in to say that the Bishop's caravan was at hand. The Bishop's caravan without the Bishop' While these were being eagerly cross-examined, other guns signalled from the valley, very distant, but volleying nearer and yet more near; and the whole settlement ran down to meet their returning friends. Among them were sad-faced and distracted women, who had gleaned from the first-comers that their husbands had perished in the great disaster. As the two Englishmen in charge of the mission station hurried forward, they met one bearing a blue pennon-the African symbol of mourning-whereon was sewn in white letters the word IсHABOD. Behind the sad standard-bearer, amid a crowd of weeping and distraught men, staggering beneath their diminished loads, a feeble crew, lean and weary and travel-stained-most of them garmentless or clothed in hides. Behind them came a battered white helmet, and the Bishop's 
friend and sharer in his peril was grasping their hands, and taken into their arms. None of them were able to say much; all were thinking of him who had gone out so hopefully, and whose great heart was now stilled for ever.'

The flag is preserved as a sacred relic in the C.M. House at Salisbury Square, London, E.C., and may there be seen by any who are interested and touched by the story of this noble career. But Ichabod? No! The glory has not departed. - Hannington did more for Africa by his death than in his life. Within a few weeks after the news came to England, fifty men had offered themselves to the C.M.S. for service in the mission-field; and Hannington's name has continued ever since to be an inspiration to many.' He holds a place with Gordon, Patteson, Gardiner, and other Christian heroes of our day in the ranks of the noble army of martyrs. 


\section{Chapter XII}

\section{THE STORY OF UGANDA SINCE HANNINGTON'S DEATH}

$\mathrm{M}$ WANGA was cowardly as well as cruel, and no sooner had he compassed the death of Bishop Hannington than he began to be very apprehensive concerning the consequences to his personal safety. But as no vengeance immediately followed he began to pluck up courage again, and the missionaries-Mackay, O'Flaherty, and Ashe-were in peril. Mwanga sent for the intrepid young Scot and, aided by the moral support of his chiefs, bullied him for three hours. $\mathrm{He}$ was especially anxious to know how the missionaries had acquired knowledge of the Bishop's death; the information had come to them through native Christians about the Court, and Mwanga's curiosity remained unsatisfied. Had it not been that Mackay's mechanical ingenuity was useful to the king, all the missionaries, Protestant and Romanist alike, would probably have been put to death.

The native Christians, however, did not escape with like impunity. The king's head page, who 
had received Christian instruction, was ordered to be burnt alive-clemency was extended to him to the extent that he was killed before being cast into the fire. For a short time after that the Church in Uganda had peace, if still not without lively apprehension. In May of r886, however, the fury of the king burst out afresh, and some fifty or sixty converts were tortured and put to death. They bore their martyrdom like Christian heroes. The Son of God was present with them in the fire. Thirty-two were burnt alive in one huge pyre. The anguish of the missionaries may be imagined at seeing their friends, with whom they yesterday talked and prayed, to-day ruthlessly seized and hacked to pieces almost before their eyes, and their members left lying to decay by the roadside.

We will not go into a detailed description of the barbarities inflicted upon the Christians. It would be too harrowing. We shall mention only one case. Roberto was engaged in his house, holding prayers with several lads, when the executioners appeared before his door. All the lads but one bolted through the thin reed wall and escaped. The ministers of Mwanga's fury seemed in awe of Roberto.

'Do not be afraid that I will shoot you,' cried Roberto ; 'come in and take me.'

Accordingly he was bound, and with his friend brought before the king, to whom he did not deny his faith. 'Take him and roast him,' was the 
sentence of the savage potentate. The lad's friends, by paying a heavy fine, got him off, but for Roberto there was no mercy. He was kept a few days in the stocks, and then one of his arms was cut off and roasted before his eyes. Next a leg was severed, and that also burnt; what was left of the poor man was committed to the flames. The executioner reported to Mwanga that never such fortitude and endurance as that shown by the Christians had he ever seen, and that the victims prayed aloud to God in the fire. The brutal monarch and his brutal Court merely laughed, remarking, with a triumphant chuckle, that God had not rescued them from the power of King Mwanga.

The Christians fled into hiding-places. From time to time visitors came to the missionaries under the cover of night, new inquirers brought in by the influence of the heroic deaths they had witnessed.

The missionaries, while themselves escaping danger, became convinced that their presence in the country only added to the danger of the converts, and sought to withdraw. Mwanga, with that perversity so characteristic of him, was rather inclined to tolerate the work of the missionaries than let them leave the country. Finally, he drew the line at Mackay. Mackay was useful to him, and he was also held as a hostage in case the white man should seek to punish Mwanga for the murder of the Bishop. Accordingly Mackay 
was alone in Uganda from August I886 until July I887. The stress of the persecution was relaxed, the Christians began to creep out of their hidingplaces, and the work of God seemed again on the path of quiet progress.

But the Arabs could not forgive Mackay for his diligence in the Gospel, nor for the influence, by reason of his usefulness, that he had acquired at the Court, and were unremitting in their intrigues against him. They were at length successful. Mackay was sent away, but Mwanga insisted that the Rev. Cyril Gordon, ${ }^{1}$ who was then at the south end of the Victoria Nyanza, should take his place. The sole recommendation of Gordon in the eyes of Mwanga was the name he bore. Here surely was a striking illustration of 'the magical power of General Gordon's influence; for Mr. Gordon was merely a namesake of the General, and Khartoum is nearly rooo miles away from Uganda.'

Gordon accordingly stepped into the place of Mackay in August I887, and remained alone in Uganda until April 1888, when he was joined by the Rev. R. H. Walker. Mr. Walker was received by the king with great cordiality and ceremony, but his smiling face covered a most diabolical design. He seemed to have resolved to throw himself back into the sheer heathenism from which he had first been rescued by the Mohammedans, and formed a plan to convey all 1 Hannington's nephew, and a member of his first expedition. 
the principal ' readers' to a small island on the lake and leave them there to starve. The victims got wind of what was in store for them, and refused to accommodate themselves to the king's little manœuvre. By combining Christians and Mohammedans against himself Mwanga had made a false step, and his own position began to be insecure and perilous.

The Christians and Mohammedans combined to overthrow Mwanga. They gathered an army, and by two different roads entered the capital on August I, I888. Mwanga fled with his women-folk to Magu, on the shores of Speke Gulf, right at the opposite corner of the lake from Uganda. There he was virtually a prisoner under the control of the Arab slave-traders. Kiwewa, an older son of Mtesa than Mwanga, and the nominee of the Arabs, was placed on the throne. Not a drop of blood was shed. The high offices of state were distributed among the two parties, liberty of worship was proclaimed, and the natives buzzed about the mission stations like swarms of bees.

But not for long could the Arabs be contented with less than supremacy. They concocted a story that the Christians wanted a woman on the throne of Uganda, just as there was a woman on the throne of England. The Christians were suddenly attacked on October I2, and forced to flee for refuge to Nkole, a land on the north-east shore of the Albert Edward Nyanza. The mission stations, English 
and French, were destroyed; Mr. Gordon and $\mathrm{Mr}$. Walker, with the two French priests, were thrown into a miserable hut, full of vermin. A few days later the whole party of both missions, thirty-nine souls in all, were put on board the C.M.S. Mission boat, the 'Eleanor,' and sent away. 'We do not want to see a white teacher back in Uganda,' was the farewell salutation of their enemies, ' until we have converted the whole country to the Mohammedan faith.' The party had various unpleasant experiences on the voyage of twenty days, one of them entailing the drowning of five of their members. At last they reached Ukumbi, on the south-east of the lake, where they were received in a kindly manner by the Frenchmen. Another day's journey brought the Englishmen to Mackay's station at Usambiro.

The Arabs shortly afterwards deposed and murdered Kiwewa and set up Kilema, another son of Mtesa, in his stead. This second revolution had not been accomplished without bloodshed. Mwanga now succeeded (I889) in establishing himself in one of the islands adjoining his country, and asked that teachers should be sent to him. Mr. Gordon and Mr. Walker accordingly went to him. He began to seek the alliance of the Protestant Christians in order to regain his throne. An army was got together which marched against the force dominated by the Arabs, overthrew them, and entered the capital. The commander of the 
victorious expedition, who was now made Prime Minister, was Apolo Kagwa, a young chief who had suffered grievous cruelty at the hands of Mwanga, now set on the throne again by the very men whom he had persecuted and driven out.

The joy at this new and happy turn of affairs was overclouded by the death of Mackay from fever at Usambiro on February 8, 1890. By his zeal, constancy, and wisdom, by his mechanical genius and his gift of languages, Mackay had made himself a household word and a power in the whole region. His hopefulness and courage never failed him. The misfortunes which overtook the Uganda mission at various times were regarded by timid and fearful souls at home as indications from God that the work there should be abandoned. When Mackay heard of these proposals, he wrote: 'Are you joling? If you tell me in earnest that such a suggestion has been made, I only answer Never! Tell me, ye faint hearts, to whom ye mean to give up the mission? Is it to murderous raiders like Mwanga, or to slave-traders from Zanzibar, or to English and Belgian dealers in rifles and gunpowder, or to German spirit-sellers ? All are in the field, and they make no talk of "giving up" their respective missions!' That was the spirit which burnt in the heart of Mackay to the end of his brief life.

Going back for a few lines in this narrative, we ought to state here that Hannington was succeeded 


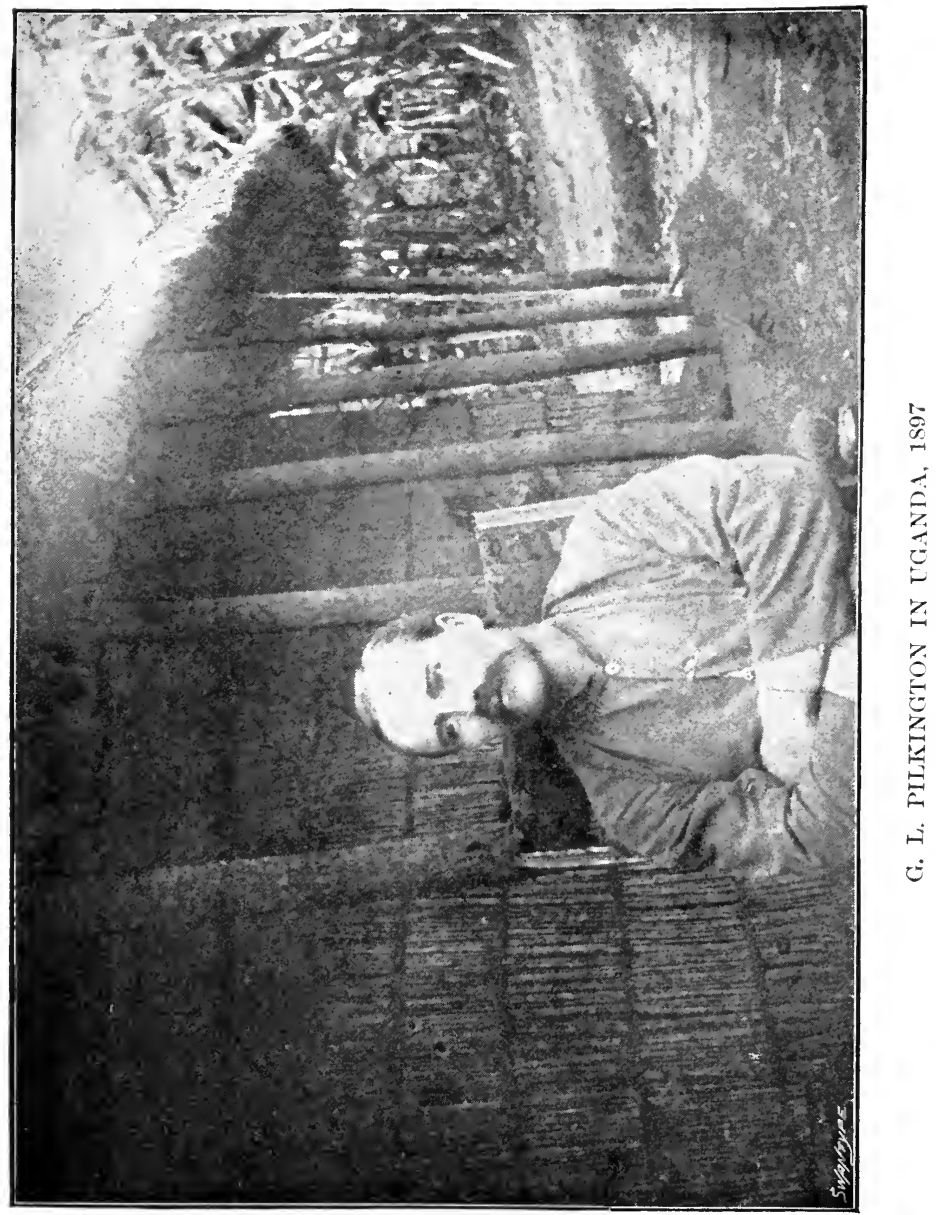



as Bishop of Eastern Equatorial Africa by Henry Perrott Parker, a graduate of Trinity College, Cambridge, who had done noble work as a missionary in India. But Bishop Parker, consecrated in September 1886 , was, like his predecessor, fated never to set foot in Uganda, for he was slain in the spring of I888 by fever on the shores of the Victoria Nyanza.

G. L. Pilkington, G. K. Baskerville, J. D. M. Cotter, and Douglas Hooper, a band of Cambridge men destined for East Africa, said farewell to their friends at a densely crowded meeting in Exeter Hall on January 20, I89o. Sixty undergraduates of Cambridge, accompanied by Dr. Handley Moule, then Principal of Ridley Hall, travelled up to London to bid farewell to their comrades. During a period of four months' waiting on the coast, Pilkington gave proof of his linguistic powers by acquiring an acquaintance with Swahili and other tongues.

Three months after the Exeter Hall meeting Alfred R. Tucker was consecrated third Bishop of Eastern Equatorial Africa. He was an Oxford man, an athlete, and an artist, and had been curate of St. Nicholas, Durham. When he arrived in Africa he received the sad news that Cotter, one of the four Cambridge men mentioned above, had died from fever the day before. But before Bishop Tucker started on his journey from Zanzibar to the lake, four other men had reached him from England. The weary four months' march into the interior had not been begun when one of the latest arrivals 
died. At Usambiro, Mr. Hunt, an official of the British East Africa Company who had given up his post to join the missionary party, and J. W. Dunn, one of the latest arrivals, died. That left six out of ten. These six suffered terribly from fever, but were revived by the twenty-three days' sail across the lake to Uganda. In the meantime Pilkington had already acquired a working knowledge of the language, and as soon as he landed in the country he set about preparing candidates for confirmation.

Bishop Tucker, then, set foot in Uganda on December 27, I89o. Before his coming a large new church had been erected by the native architects $8 \mathrm{I} \mathrm{ft}$. long by $24 \mathrm{ft}$. broad. It was thronged daily by worshippers and learners. Some 300 converts had been baptized. The Gospels according to Mark and John were about to issue from the press, as well as parts of the PrayerBook. Bishop Tucker, the day after his arrival, preached to a congregation of rooo people, including the Prime Minister. $\mathrm{He}$ had brought up with him a stock of Swahili New Testaments, which were eagerly bought up at the price of three months' wages by those who understood that language. Then, after doing all that the immediate situation seemed to require, he set out for the coast, on his way to England, there to proclaim the needs and the opportunities of Uganda. The prospect indeed seemed fair.

But a fresh storm was brewing. Questions of 
international politics began to stir up bloody strife in the country. The British East Africa Company had been established; before Mwanga had recovered his throne he had applied for assistance from an agent of the Company, and this agent had sent Mwanga one of the Company's flags. The king, in accepting it, had placed himself -though probably he did not understand the full import of his act-under the protection of the Company. A little later Dr. Karl Peters, a German explorer, arrived at Mengo, and induced Mwanga to sign an agreement with him. ${ }^{1}$ The French Roman Catholic priests, who had arrived in the country two years after the C.M.S. first party, did not welcome either of these steps. They wanted Uganda for France, but they would rather see it in the hands of Germany than of England.

There were soon three distinct parties in Uganda - the French or Roman Catholic party, the English or Protestant party, and the party of heathendom to which the great mass of the inhabitants belonged. Sir Frederick Lugard and the officers of the British East Africa Company 'tried to act impartially and distributed chieftainships and provinces to the best of their ability.'

The situation was soon rendered peculiarly precarious for the English party by the common

1 This agreement was rendered nugatory by a subsequent treaty signed in Europe which limited Germany to the southern end of the Victoria Nyanza. 
report that the continued occupation of the Company was more than doubtful. The expense of holding the country was more than they could afford and there was no immediate prospect of a commercial return. When their approaching withdrawal was announced, there was something like a panic in English mission circles. The Company had been the guardians of the peace in Uganda between the conflicting parties ; their evacuation of the territory would mean civil war and anarchy, the loss of many lives and the ruin of the mission. To stave off the immediate peril Sir William Mackinnon, a leading director of the Company, guaranteed half of the $£ 40$,000 which was required for maintaining the Company in Uganda for another year, if the friends of the C.M.S. would find the other half. Bishop Tucker, at a crowded meeting in Exeter Hall on October 30, r89r, told his story with thrilling power and awoke the audience and the country to the peril of the situation. Within a few days $£ \mathrm{I} 6,000$ was handed over to the Company and the withdrawal was cancelled.

But in the meantime the opposing factions in Uganda had come into armed conflict. Captain Lugard, with a body of Soudanese soldiers, had fortified one of the eminences on which Mengo is built and thus for a time kept the peace in the capital. But the continued prevention of the daily brawls in the streets was beyond his power. The situation came to a crisis when in January 
I 892 the French party attacked the English party, killing Sembera, one of the noblest, most conspicuous and best beloved of native Christians. They actually turned their strength upon the position held by Captain Lugard, but the fire of his Maxim gun sent them upon a flight which did not end until they had reached the Sese Islands.

The French party carried off Mwanga, who had been on their side because he thought they were going to be the victors in the fight. But when fortune had turned against them he sought and found an opportunity to escape from their midst, and, returning to Mengo, declared himself a Protestant. Then the French party submitted, and Captain Lugard assigned to the priests the province of Budu, in which they were permitted to labour without interference.

We consider that this was to treat the Jesuits with generosity, particularly as they were not required not to interfere in the Protestant provinces. They would have been well advised and well inspired never to have entered Uganda. They arrived on the scene two years after the English missionaries; they must have known that their presence would stir up strife and impede the Christian civilisation of the people, and their intrusion was quite gratuitous, for there were only too abundant opportunities for them in parts of the heathen world which had never been visited by missionaries, Protestant or Romanist. 
When peace was restored the native Christians set about the erection of a great cathedral, capable of holding 4000 people, for the capital. The walls were made of reeds, the roof was thatched with grass and supported by a perfect forest of poles. The missionaries hit upon a novel way of determining how many persons were present at the opening service. Each person, rich or poor, was requested to contribute one cowrie shell only; 373I cowries were given at the service.

The most urgent need and demand of the people was for Christian literature. When Pilkington reached Uganda in December I89o, the four Gospels had been translated by Mackay, Ashe, and Gordon, and St. Matthew's Gospel had been printed. Assisted by native helpers, Pilkington within two years-and these years included months of great insecurity-completed the translation of the New Testament, several books of the Old Testament, Bible stories, and hymns, and did a great deal of work on a grammar of the language. The difficulties of these labours were monumental, for no grammars or dictionaries existed and there are many words and ideas in the New Testament for which it is a very delicate business to find equivalent expressions in the language of an uncivilised heathen race. Pilkington's speed as a translator has never been surpassed. Most of these versions had to be printed in England, and having to be carried on men's heads from the coast to 
Uganda, they cost a terrific figure when they reached their destination. A New Testament cost rooo cowries, or the price of five weeks' food. Yet the books were eagerly bought and as eagerly read.

In the early part of 1893 the British Government took over Uganda, and the Union Jack replaced the flag of the British East Africa Company. In March, forty Protestant chiefs, without pressure from the English, published a joint decree, setting their slaves free. The Baganda, now become missionaries to others, began to carry the Gospel to their neighbours. Three Baganda teachers were set apart for work in Busoga. Six were ordained deacons, thus beginning a native ministry. Mika Sematimba, a Christian chief, whose gentle, kindly face attracted everyone, visited England, accompanied by the Rev. R. H. Walker, and appealed for more missionaries.

Pilkington had occasion, at the beginning of I894, to go on an expedition which revealed to him how little the knowledge and influence of the Gospel had spread beyond the neighbourhood of the capital. Within a few months he and $\mathrm{Mr}$. Baskerville, borrowing the idea from the Rev. A. B. Fisher, had planted about 200 'reading houses.' At each of these a little group was ' taught by a teacher, who was himself under the guidance of a more experienced worker, the whole being supervised by the European missionary.' It was 
a wise and practical application of the principle of devolution.

The new plan was a great success. Twenty thousand persons assembled every Sunday to hear the Gospel. Within a few months 800 persons were baptized and the number of catechumens rose from I70 to I500. The version of baptism that acquired currency among the heathen still outside the Church was that it consisted of 'making a hole in the head and rubbing in a powerful medicine, which kills the old heart; and then there comes in its place a new religious heart that does not lust for anything.' This was surely striking testimony to the reality and depth of the work that was being done by the missionaries in the power of the Holy Spirit. In this same year the cathedral was blown down, and while it was being rebuilt twenty churches were erected near the capital. And so the seeming evil wrought for good; for in this way the seed of the Gospel was scattered abroad.

Up to this time no European woman had set foot in Uganda. The perils of the way and of the country itself forbade the C.M.S. to allow women to run the risk. But the northern route, first traversed by Hannington, was comparatively healthy, and the danger from the Masai warriors had much diminished with the advent of British authority. Accordingly five ladies were chosen to be the pioneers of lady missionaries in this interesting and promising field. Accompanied by five men, 
the whole party being under the command of Bishop Tucker, they arrived in Mengo on October 4, I895, amidst a scene of tumultuous excitement. The Baganda women flung themselves upon the English ladies in rapturous joy. Already six native women had been at work as deaconesses for two years, and these were able to facilitate the operations of their new fellow-labourers from far across the sea.

The mission was now making simply wonderful progress. The report for 1897 gives the number of native Christian lay-agents as 659 , baptisms during the year 4442, and native Christian adherents, including catechumens, 12,856 . Mr. Mullins points out that in 1896 and 1897 the number of the adult baptisms was very nearly half of the total recorded for the whole of the C.M.S. missions.

The printing of Pilkington's translation of the Bible was completed in the autumn of 1897 . Three inches broad and three inches thick, it has become known as the biscuit-tin Bible, because it fitted nicely into one of Huntley \& Palmer's 2-lb. biscuit tins, which were plentiful in Uganda. But this circumstance was accidental, though very convenient, for biscuit tins are of great service in preserving books from the ravages of ants and other insects.

But what about Mwanga all this time? He was still King of Uganda, but under a British pratectorate he had no longer licence to rob and kill 
as he chose. He had security and prosperity, but these were not enough for him. So one night in the summer of 1897 he stole away from his capital, joined the Roman Catholic party at Budu, raised the standard of revolt and summoned his people to help him to drive out the Europeans, kill the native Christians, and return to the old days. He was defeated and driven into German territory, where he was held a prisoner. He was denounced by the British as an outlaw, and his infant son, a few weeks old, the son of a Protestant mother, was proclaimed as King Daudi Chwa, which, being interpreted, means 'David, the fly!'

Soon after a serious mutiny broke out among the Soudanese troops, upon whom the British mainly depended for the peace of the country. Three hundred of them, who had gathered at a place east of Busoga to take part in an exploring expedition to the north, seized the fort at Lubwa's, and murdered three Englishmen. It was feared that the Soudanese at Mengo might become dangerous to the British, out of sympathy with the mutineers, and accordingly they were disarmed. A body of Baganda under British officers was sent to Lubwa's, but the siege of the fort proceeded very slowly because of the smallness of the attacking party and of the immense banana fields which surrounded the position. Many of the besiegers lost their lives. While these things were going on, Mwanga escaped from the Germans and again showed his 


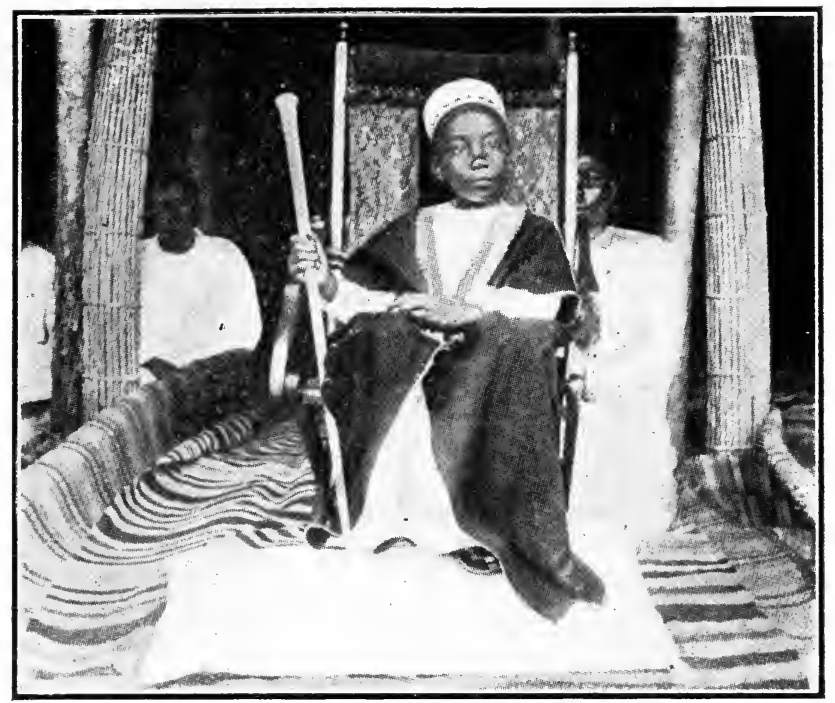

KING DAUDI CHWA IN STATE

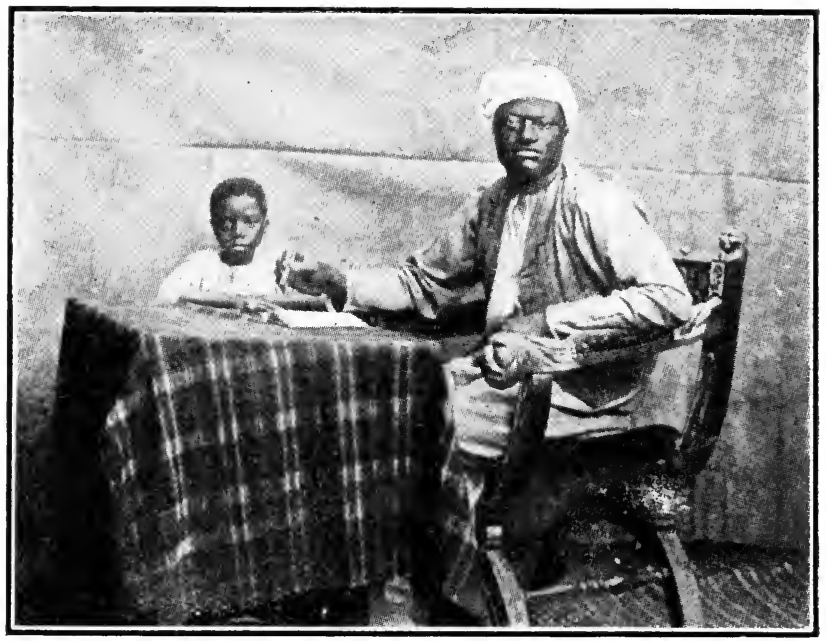

APOLO KAGWA, KATIKIRO OF UGANDA AND HIS SON 

face in Budu, but he was very soon put to flight. In the same month, December, the noble career of Pilkington, so far as it was to run its course in this earth, came to an end. As interpreter he had accompanied the Baganda troops to Lubwa's, and early one morning, in a hidden sally of the mutineers, he was mortally wounded by a shot in the thigh which severed a main artery. Aloni, his native 'boy,' saw the change in his face, and said to him-

' My master, you are dying. Death has come.'

' Yes, my child,' said the dying man, ' it is as you say.'

'My master,' continued Aloni, ' he that believeth in Christ, although he die, yet shall he live.'

'Yes, my child,' again answered his master, ' it is as you say--shall never die.'

His life quickly ebbed away, and the same evening he was buried under a tree near the spot where Hannington had been murdered twelve years before. ${ }^{1}$ The Baganda mourned him deeply. 'We all shed tears,' wrote Henry Wright Duta; ' we cried our eyes out.'

Some Sikh troops arrived from India in the following month, and the mutineers perceived that their game was played out. Abandoning the fort in the night-time, they were pursued north-

1 Afterwards the remains were disinterred and buried at Mengo, where Bishop Hannington's bones, so strangely recovered, had been laid. 
wards beyond Lake Kioga, captured, or dispersed. For over a year, however, Mwanga and the slaveraiding King Kabarega, though they had ceased to menace the capital, continued to be troublesome, until in March I899 they were captured and banished to the Seychelles. Mwanga, removed from the scene, had no longer a shred of influence, and he died in I903-forgotten. $\mathrm{He}$ had been baptized and had given signs, it is said, of true repentance.

Our readers will readily understand that in this rapid sketch we are merely noting the points of exceptional interest in connection with the Uganda Mission. There are very important features of work common to all missions, such as education, women's work, and the like, which do not, in such a sketch as ours, call for special mention. We must, however, note the industrial work, because it has a bearing on the erection of the great brick cathedral which is the glory of the ecclesiastical architecture in the country.

Industrial mission work in Uganda took on its first noteworthy development under Mr. K. E. Borup, a Canadian of Swedish extraction, who in the course of I899-I900 trained six Protestant lads in printing and carpentry. Mr. Borup and his lads set up, printed and issued a four-page leaflet periodical, called Mengo Notes. Then the master set himself to teach carpentry and building. Soon a tremendous demand was made upon his 
resources and his ingenuity. The huge cathedral of reeds and thatch was in a parlous condition, and the Prime Minister decided that the new building must be of brick. But bricks had been introduced into Uganda only a few years before, and a building of brick of the size of the new cathedral had never even been dreamed of by the Baganda Christians in their wildest moments. The idea must have seemed as doubtful and as marvellous to them as the structure of glass and iron erected by Sir Joseph Paxton in I85I for the housing of the first great international industrial exhibition.

What was to be done? Mr. Borup rose to the occasion. He taught brick-making. He constructed a huge brick-making machine capable of turning out 3000 bricks a day. It was calculated that at least a million bricks would be required. How was the material for all these bricks to be obtained? Volunteer labourers were forthcoming. The great chiefs, with the Prime Minister himself at their head, went in state to the clay pits, and marched back to the sound of the drum, with great balls of clay on their heads, to the place where the bricks were to be made. The great ladies of the country, the princesses and chiefs' wives, went in similar fashion into the forest and carried back bundles of brushwood to the brick-kiln fires.

The notables of the country voluntarily taxed themselves to meet the cost of the cathedral. 
It was to be cruciform in shape, with walls of brick and roof of thatch, lighted by seventyfour windows and entered by ten doors, and capable of accommodating 4000 people. King Daudi Chwa laid the foundation-stone on June I8, I90r. This stone was a large block which had been used to mark the grave of Pilkington before a marble cross arrived from England for that purpose. The first service was held on June 26, 1902, the day on which King Edward, but for his sudden illness, would have been crowned. The people were summoned to the ceremony by the immense booming of a drum five feet high, presented by Henry Wright Duta. This substitute for 'sweet chiming bells' was in harmony with the customs of the country.

The most remarkable circumstances in connection with the consecration of the cathedral on June $2 I$, I904, by Bishop Tucker, in the presence of a vast concourse of people, related to the collection. This consisted of I3 cows, 4 goats, I25 eggs, I30 fowls, 75,000 cowrie shells, 500 rupees in coin, 600 rupees promised, and 1064 pice. The money only represented $£ 85$ of our money. The cows were tied up outside the cathedral, but the goats were led up to the communion rail by a rope, and the Bishop, after having duly received them, returned them to be tied up outside. The fowls were received in large crates made of sticks, and the shells were given in bundles fastened with the 
dried banana fibre. The sidesmen were not content with collecting from the congregation inside, but brought in large bags full from the crowd outside, who had been standing patiently for hours in the sun with their offerings ready.

Uganda for the last few years has been developing in a quiet, peaceful manner. Not that there are not some disquieting and even distressing factors in the situation, to which we shall refer presently. A new settlement of the country was made in I900 by Sir H. H. Johnston, the British Special Commissioner, who instituted a hut tax of three rupees, a very large sum to people who reckon in cowrie shells, of which at least 600 go to the rupee. But the tax is not oppressive, and has stimulated many thousands of lazy people to activity. Further, the tax may be paid in kind. A live young elephant is payment for Iooo huts, a hippopotamus for Ioo huts, a tame zebra for 30 huts, a live young zebra for 20 huts, a live goat for one hut. At times the seat of Government bears a marked resemblance to a menagerie.

Sir Apolo Kagwa, the Prime Minister, is the most influential native personality in Uganda. $\mathrm{He}$ is one of the triumphs of the Gospel in that country; his powers as a leader in war and a ruler in peace, and his sound Christian character, have made him a mighty force for good. On his visit to England in I902 his dignity and intelligence made a good impression. He pleaded before the C.M.S. Com- 
mittee that 200 European teachers might be sent to Uganda and the surrounding countries. A few years ago he was knighted by King Edward.

The medical missionary is playing his superbly useful part in Uganda as in other parts of the missionfield. Dr. A. R. Cook ${ }^{1}$ arrived in Uganda in I897, and within a few months the 'mission hospital,' a reed structure, was opened with Miss Timpson as nurse and chief member of the staff. A new ward to accommodate twenty beds was added in the following year, and in I899 a new hospital altogether, in the form of a double Maltese cross, was constructed, with accommodation for fifty beds. The Prime Minister and the other chiefs provided all the labour. Dr. J. H. Cook now went out with his wife to reinforce his brother.

Miss Timpson has recorded some amusing instances of her struggles with the ignorance and obstinacy of the out-patients. For example, she is handing to one of them a box of pills, explaining that they are very strong, that he is to take one pill morning, noon, and night, and that the supply is to last three days, when, lo! and behold! the nurse's back being turned, the patient, who has not been listening but feasting his eyes on the box, proceeds to swallow the three days' supply at once, and it is a question whether one of them is rescued from his throat! The consequences will certainly not

${ }^{1}$ See $A$ Doctor and His Dog in Uganda, published by the R.T.S. at 2 s. 
be pleasant to the patient, and may cause the doctor considerable trouble and anxiety.

The medical mission work has, of course, grown with the other operations and the development of the country. Towards the end of November the hospital was struck by lightning and burned to the ground. All the patients were saved, though only after heroic efforts by Europeans and natives, but most of the surgical instruments were destroyed. The chiefs at once agreed to furnish bricks and timber for the new building. 'If God has allowed our hospital to perish,' remarked the Prime Minister, "it is to show that we must build a bigger and better one.'

The construction of the railway from Frere Town to the northern shore of the Victoria Nyanza has of course altered, almost beyond recognition, the conditions of the problem which Uganda represented in the pre-railway days. The sufferings of the missionaries and the porters in the terrible journey from the coast are a thing of the past. No long journey or large caravan was organised which did not cost suffering and loss of life to many natives, through privation, disease, the hostility of wild beasts and of men scarcely less wild. One of the most valuable results of the construction of the railway has been a staggering blow to the slave trade on the East Coast of Africa. For the making of the railway large numbers of coolies had been brought from India, and the problem fo supplying them with food, 
while at work, for example, in a waterless desert, was only solved by the exercise of much ingenuity and toil. Some districts along the line were terrorised by lions which carried off quite a number of the labourers. The journey from the coast to the northern shore of the Victoria Nyanza, which formerly took months, can now be accomplished in three days. A service of fair-sized steamers now does the crossing of the lake to Entebbe in Uganda in about thirty hours.

A journey to Uganda is now a pleasure excursion. 'Cook's' take tourists out from England to the East Coast of Africa, thence by rail and boat to Uganda, returning down the Nile past Khartoum and other spots made so familiar by the recent history of Egypt. Bishop Tucker has described his satisfaction at being able to look out of a railway carriage window as he was carried past the scene of former trying marches.

The flag of the Gospel has been carried into many of the countries round about Uganda, and under that banner many signal victories for Christ have been won. On the northern shore of the Albert Edward Nyanza, 200 miles west of Mengo, and east of the mountains of Ruwenzori, lies the land of Toro. Captain Lugard in $\mathrm{r} 8 \mathrm{~g} \mathrm{I}$ placed on the throne of Toro the lad Kasagama. At that time Kasagama's brother, Yafeti, was in Mengo, and on the occasion of two visits to his native land brought with him Baganda Christian teachers. 
King Kasagama, the Queen-Mother, and fourteen other Batoro, were baptized in I896. The king, who took the name of Daudi (David), showed himself to be a Christian in deed as in profession. When any difficult matter came up for discussion, he always asked himself, "What ought I to do as a Christian ?'

In the following year King Daudi sent a letter to 'the Elders of the Church in Europe' appealing for more teachers. 'I want very much,' he said, 'God giving me strength, to arrange all the matters of this country for Him only, that all my people may understand that Christ Jesus, $\mathrm{He}$ is the Saviour of all countries, and that $\mathrm{He}$ is the King of all kings. The teachers are few, and those who wish to read many. Therefore, sirs, my dear friends, have pity on the people in great darkness. I want my country to be a strong lantern that is not put out, in this land of darkness.'

Strange sights might be witnessed in the Christian schools at Toro. Here might be seen the Prime Minister himself, struggling with the mysteries of elementary arithmetic. He would have it for a long time that twice two made twenty, and that thirteen should be written I03; when at length he understood the notation he rubbed his hands with delight, exclaiming, ' $\mathrm{Oh}$ ! what wisdom we have!'

West of Toro, on the borders of the Congo Free State, is the land of Mboga, at the edge of the 
famous forest inhabited by pygmies. The Gospel was introduced into Mboga by the chief of the country, who happened to be in Toro when 'the good news' was brought to that land. The progress of the Gospel received a blow by the arrest of Apolo, the principal Christian teacher, who had come from Uganda, on a charge of murder. A Christian woman had accidentally impaled herself on a spear which had been carelessly left outside her house in a most awkward position. Apolo happened to be near the spot at the time of the accident, and went to the assistance of the poor woman, who was in her death-agony. Some passers-by whom he summoned to his help accused him of murdering the woman. He was arrested, sent to Toro with his accusers, but the British officer before whom the case came, so firmly convinced was he of Apolo's innocence, discharged him without even the formality of a trial. Apolo on another occasion had suffered much for the cause of Christ, had lain in prison, been beaten, and lost all his worldly goods. He had sacrificed comfort in Uganda in order to carry the Gospel to his brethren. Seduraka, a fellow-labourer, was declared by his friends and kinsmen in Uganda to be a madman for returning to work at Mboga. 'I would,' said Bishop Tucker, 'that there were many such madmen in the world as Apolo and Seduraka.'

Let us turn to another corner of the map. Not 
far from the south-east corner of the Victoria Nyanza are the stations of Msalala and Usambiro, which have already been mentioned more than once in this little book in connection with Hannington and Mackay, Now, Msalala and Usambiro are in the country known as Usukuma, now part of German East Africa. This portion of the field stirs up memories, sad as well as glad. When Bishop Tucker visited Usambiro on his first journey to Uganda, he found the graves of five missionaries there-those of Mackay, Bishop Parker, Blackburn, Hunt, and Dunn.

The central and principal mission station in Usukuma is at Nassa, on the southern shore of Speke Gulf. The fruit of the Gospel, though the country is populous, has not been so plentiful as in Uganda, though it is sound and good fruit. The converts are real and true, no ' rice Christians' among them. Daudi Mbasa, the first-fruit, refused an important chieftainship, and put away a number of wives, for the sake of the Gospel. Sunday is observed by heathen and Christians alike on the shores of Speke Gulf. The missionaries run up a red-cross flag to let the people know it is the Sabbath day.

Bunyoro was for years known only as the land of the slave-raiding King Kabarega, a name of terror. It lies north of Toro, and along the eastern shore of Lake Albert. The religion of the people in the old days consisted of devil-worship. The 
evil spirit was propitiated by the torture and sacrifice of human beings. The moment a baby was born it was scarred with a sharp knife and dedicated to the devil. If the baby had a pain in the head or chest, and cried, that was taken to signify that the devil was angry, and the poor little thing was burned with a red-hot iron on head and chest. His teeth, as they arrived, were painfully extracted. A little girl was once brought to a missionary with a deep wound in her forehead, caused by her mother firing a blunt arrow at the child's head that she might draw blood and cure pain. These cruel superstitions are all but dead.

When King Kabarega was banished, the British administrator placed his little son of ten years of age on the throne. The lad had received Christian instruction at Mengo, and it was hoped that Yosiya would be a firm, just, and merciful ruler. The first convert was a lad called, on account of his fiery nature, Fatake or Gun-cap. People told him that if he became a Christian he would lose everything. 'But,' said he, in his first sermon, ' what have I lost except my evil habits ?'

A wonderful service took place at Koima, the capital of Bunyoro, on the occasion of a visit from King Daudi Kasagama of Toro and several Christian chiefs. One after another, says Mr. Mullins, got up and testified what the Gospel had done for them. 'The last time we came to you here in this country,' said one of the chiefs, "we came with shields and 
spears in our hands and hatred in our hearts ; now we stand before you with God's Word in our hands and His love in our hearts.' King Yosiya, who had proved weak and unfit for his position of authority, was deposed, by petition of the chiefs, and in his stead reigned another son of Kabarega, named Andereya, a young man and a zealous Christian. The joy of the missionaries was great, for no Christian worker had been more constantly helpful than Andereya.

In the descent of the Nile from the Victoria Nyanza to Lake Albert, the river passes through Lake Kioga, to the north of which is the land of Bukedi, wherein dwelt a strange unclothed race. When the Rev. G. R. Blackledge visited the country in I899, the girls thrust out their tongues at him to show that they wore rings through them, and then proved that they could work off the rings if they liked. Mr. Blackledge invited the natives to receive teachers; and to discuss this matter a great palaver was held, to which a crowd of men came fully armed. 'Each debater marched up and down between the long lines of men as he spoke, brandishing shield and spear to emphasise his words. At length the answer was given-

" "Formerly the Baganda used to make raids upon us. The teaching that has made such a change must be good. We will receive the teaching.'

Mwanga and Kabarega, when their case was desperate, had fled to Bukedi ; they were rooted out, 
and the country was placed under the direction of a Christian chief from Uganda, named Semei Kakungulu, a man of very earnest character and distinguished personal bravery. The people of Bukedi are a fine race-tall, well-proportioned, athletic, and courageous. Though they believe in witchcraft and worship devils, they are strictly moral. They are now being instructed by teachers from Uganda, and a rich harvest of souls may be expected in due season.

The Bahima, who inhabit Nkole, a small territory to the east of Albert Edward Nyanza, are believed to be the descendants of a tribe of Asiatic invaders. They are light brown in colour, and have thin but wiry bodies. They have been described as natural gentlemen. Their women, who are often beautiful, are-when not Christian-kept secluded, and are veiled when they appear in public.

Christianity was introduced into the country at the beginning of r9oo, and at the close of the year a striking scene was enacted. The Prime Minister brought all his charms and fetishes to the Christian teacher, saying that he wished them burnt. It was resolved to make the ceremony a public one, in order that the peasants might be disabused of a prevalent idea that the Christians retained these surrendered charms for their own benefit. When the king heard of the proposal, he ordered that the burning should take place in the courtyard of his palace. There his majesty, surrounded by his 
chiefs, sat down to witness the ceremony. As soon as the burning began, the people commenced to bring theircharms, and there was an almost universal moving towards the fire, which was kept going half the day. Last of all the king offered up his charms to conflagration. The scene is reminiscent of a well-known incident described in the Acts of the Apostles.

After the baptism of the king, some time later, a messenger came to the missionary, saying-

'Come and see the king beat his drum.'

What this might portend the missionary did not know, but, in faith and expectation, he sallied forth. It appeared that there was a certain instrument of music-or rather of noise-known as the national drum of Nkole, and immemorial report declared that if the king of the country were to beat it disaster would follow. Now that he was baptized, King Kahaya wished to beat this drum publicly that his people might see that he had given up the old superstitions. When the folk were gathered together in the courtyard, the king rose from his chair and solemnly beat the drum. Then the people dispersed.

Among the most recent authentic statements concerning the present position and the future prospects of Uganda is that contained in an interview with the Ven. R. H. Walker, Archdeacon of Uganda, in the Record of December 6, I907. On the whole this interview makes sad reading. Disease and 
death are busy in Uganda. The population is being decimated by the sleeping sickness, a mysterious malady which up to the present has baffled the understanding and the skill of medical science. Professor Koch, the famous Berlin student of bacteriology, has recently returned from a prolonged visit of investigation to Uganda. Three thousand five hundred victims of the sleeping sickness came under his supervision ; of these 3000 died and 500 were "left to die.' Everyone upon whom this terror-striking disease fastens is doomed to death within two years.

Archdeacon Walker is the senior member of the C.M.S. Uganda Mission, and as such his information and views have especial weight. $\mathrm{He}$ points to a more fearful enemy, baleful in its effects upon body and soul alike, than even the sleeping sickness. We are referring to the inconceivable evils of impurity. Among savage races, the primitive passions, against which St. Paul had to contend so earnestly even in a civilised race, work terrific havoc. Uganda was in an evil case in this respect even while she was isolated from civilisation; but since the opening of the railway and the influx of population from Mombasa and Zanzibar, including decadent members of the Southern European populations, the physical results of vice have intensified in mischief, until now we are face to face with this appalling fact, that the Baganda, the hope of Africa, are a dying nation. The population of the kingdom of Uganda-we are not speaking of the whole Protectorate-in IgoI 
was estimated at a little over I,000,000 ; to-day it may be put at 700,000. "If the death-rate be not diminished,' says Archdeacon Walker, 'the whole population will die out in twenty years.'

For this moral sickness the only cure is a vital personal godliness. Sir Harry Johnston is emphatic that Christianity is the only hope for the people.

The great things that God has wrought for Uganda in the past, and is even now working, forbid us to despair. Sixty thousand persons have been converted and baptized in the thirty years since the mission was started ; practically all the principal men and the bulk of the ruling classes of the country are professing Christianity; a large proportion of the native Christians are leading consistent Christian lives; there is a sincere and earnest desire on the part of the people to spread the good news of the Gospel in the regions beyond; and there is practically no opposition to missionary advance in the whole of the Protectorate, which has an area of II4,000 square miles, rather less than that of the whole of the United Kingdom. The number of native Christians in the Uganda Mission, according to the latest report, is 59,926. There were 6 I73 baptisms during I9o6.

The man who, at the order of Mwanga, compassed the death of Bishop Hannington, died so recently as the summer of rgo6. It seems that at the last Lubwa, the old chief of Usoga, was seeking the Saviour whose message he had so often heard and 
rejected. Â circumstance of singular and touching interest was the baptism, recorded in the latest C.M.S. report, of a son of Lubwa by the Rev. J. E. M. Hannington, a son of the Bishop : the murderer's son is received into the Christian Church by the son of the murdered man! Lubwa's son was called Mubinyo, which means 'very bad boy'; he is called Timothy, and is described as 'amiable, cleanly, clever, painstaking, and above all truly anxious to follow the Saviour.' 


\section{AFRICA}

\section{The Redemption of Africa}

FREDERIC PERRY NOBLE

Illustrations, Maps and Tables, 2 vols., 8vo, Cloth, \$4.0o.

The subtitle of this book, "A Story of Civilization," is a most fitting supplement to the distinctive title. "No book on any land surpasses this in thoroughness of preparation, wealth of citation, impartiality of judgment, and the predominant desire to tell nothing but the truth." This testimony from The New York Sun is emphasized by every journal acquainted with missions in that land. It is practically an encyclopedia on Africa.

\section{Dawn in the Dark Continent; ${ }^{\text {Or Africa and its }}$}

\section{JAMES STEWART, M. D., D.D.}

Colored Maps, 8vo, Cloth, $\$ 2.00$ net.

There has probably been no man more competent to outline the missionary work in Africa than the veteran founder of the famous Lovcdale Institute. This is just what he has done in this volume, supplementing it by some invaluable comments on the training of a missionary.

\section{The Egyptian Sudan}

Illustrated, I $2 \mathrm{mo}$, Cloth, \$1.0o net.

This new mission field of the American United Presbyterian Church has been recently brought into prominence by John D. Rockefeller's gift to it of \$100.000. Mr. Giffen's book describes, in - most interesting style, the unique problems faced in such a country. The Interior knows of "no other book so fuil of information as to a great military and economic center on the Cape-to-Cairo railway.

\section{On the Borders of Pigmy Land}

Illustrated, r $2 \mathrm{mo}$, Cloth, $\$ 1.25$ net. RUTH B. FISHER Mrs. Fisher is a successful author and has written a book which commands the enthusiastic approval of "all sorts and conditions" of papers, missionary, religious and secular. The Mountains of the Moon, the Great Lakes, the Uganda Railway, Pigmies and other tribes combine to give a rare and sig. nificant setting to the work of the missionary.

\section{Pioneering on the Congo}

REV. W. HOLMAN BENTLEY

Illustrated, 2 vols., 8 ro, Cloth, $\$ 5.00$ net.

- The present Congo discussions acquire a new interest in the light of the conditions as brought to light by the early missionaries. No one has done this better than $\mathrm{Mr}$. Bentley, of the English Baptists. A fine scholar, a sympathetic, "accurate observer, impartial, intelligent, trustworthy." 


\section{Daybreak in Livingstonia}

Illustrated, 12mo, Cloth, \$r.50 net.

JAMES W. JACK, M. A.

"One of the best missionary histories, combining possibilities of romance almost as thrilling as King Solomon's Mines, with a calm presentation of visible and tangible results that ought to open the eyes of any who still consider Christian Missions a failure."-Glasgow Herald.

\section{In Afric's Forest and Jungle}

Illustrated, I $2 \mathrm{mo}$, Cloth, \$1.00. REV. R. H. STONE

A record of Six Years Among the Yorubans on the West Coast of Africa, with numerous tales of thrilling experiences growing out of the wars between the great African tribes." A vivacious and deeply interesting volume."

\section{The Sign of the Cross in Madagascar \\ REV. J. J. KILPIN PLETCHER}

Illustrated, I $2 \mathrm{mo}$, Cloth, \$1.00.

A pastor, appointed to visit Madagascar and report on the work of the London Missionary Society, fascinated by what he learned, has gathered up the results in story form. With reniarkably vivid touch he describes the early conditions, the coming of the "strange messengers," the "mighty faith," the bitter persecution, the divine interposition, the changes and the victory of the Cross.

\section{The Personal Life of David Livingstone}

W. GARDEN BLAIKIE, D. D.

Portrait and maps, 8vo, Cloth, \$1.50.

This standard life of the great missionary and explorer has the peculiar advantage of the special authorization by his family to use unpublished journals and correspondence. There is thus a peculiar power in its presentation of what the $S$. $S$. Times calls his "simple but noble life of self-surrender to a great motive."

\section{Pilkington of Uganda}

C. F. HARFORD-BATTERSBY, M. A., M. D.

Illustrated, 8vo, Cloth, \$r.50.

A fitting sequel to the biography of Alexander Mackay, covering with that a moral transformation equal perhaps to anything recorded even in apostolic days.

\section{A Life for Africa}

Illustrated, r $2 \mathrm{mo}$, Cloth, $\$ 1.25$.

ELLEN C. PARSONS

- This biography of Rev. A. C. Good, Ph.D., of the Presbyterian Church in the U. S. A., by the Editor of Woman's Work for Woman, is both a record of missionary service, and opens up a section of West Equatorial Africa of which little is known. 


\section{A Miracle of African Missions}

$16 \mathrm{mo}$, Cloth, 6oc net.

JOHN BELL

The story of Matula, a Congo Convert, describes a change as great as that in the Apostle Paul, as profound as that in Jerry McAuley. The Interior says, "It ought to be digested and preached in every pulpit in the land."

Adaora : The Romance of a West African Girl.

Illustrated, I 2mo, Cloth, 5oc net.

MARY E. BIRD

"An excellent book," so says The Christian Observer, "for our young people's missionary library."

\section{Missionary Biographies Series}

Illustrated, I amo, Cloth, each $75 \mathrm{c}$.

Albert Moffatt

DAVID J. DEANE

The Missionary Hero of Kuruman.

Samuel Crowther

JESSE PAGE

The Slave Boy who became Bishop of the Niger.

Thomas J. Comber

REV. JOHN B. MYERS

Missionary Pioneer to the Congo.

Madagascar

W. J. TOWNSEND, D.D.

Its Missionaries and Martyrs.

Thomas Birch Freeman

REV. JOHN MILUM

Missionary Pioneer to Ashanti, Dahomey and Egba.

The Congo for Christ

REV. JOHN B. MYERS

The Story of the Congo Mission.

David Livingstone

A. MONTEFIORE

Missionary and Explorer.

\section{Missionary Annals Series}

I $2 \mathrm{mo}$, Paper, each 15c; Flexible Cloth, each $30 \mathrm{c} \mathrm{net.}$

Robert Moffatt

David Livingstone

Madgascaar
M. L. WILDER

MRS. J. H. WORCESTER

BELLE MCPHERSON CAMPBELL

\section{Biographies : World's Benefactors Series}

Illustrated, 12mo, Cloth, each 75c.

David Livingstone ARTHUR MONTEFIORE, F. R. U.S. His Labors and His Legacy.

Henry M. Stanley ARTHUR MONTEFIORE, P. R. G.S. The African Explorer. 


\section{Poland, the Knight Among Nations}

With Introduction by Helena Modjeska.

Illustrated, Cloth, $\$ 1.50$ net.

LOUIS E. VAN NORMAN

Poland is worth knowing-it is interesting. How could it be otherwise when it gave us Copernicus, Kosciusko, Chopin, Paderewski and Sienkiewicz. Not much has been known about the people because they have been hard to get at. Mr. Van Norman went to Cracow, won the hearts of the people, was treated like a guest of the nation and stayed till he knew his hosts well, and he here conveys an extensive array of information.

\section{The Continent of Opportunity: south America}

Profusely illustrated, $\$$ 1.50 net.

FRANCIS E. CLARK

Dr. Clark writes from a thorough-going tour of examination, covering practically every centre of importance in South American continent, Panama, Chile, Ecuador, Peru, Argentine, Brazil, Paraguay and Uruguay. Dr.' Clark's prime object has been to collect information of every sort that will help to understand the problems facing Civilization in our sister Continent.

\section{China and America To-day}

$12 \mathrm{mo}$, Cloth, $\$ 1.25$ net.

ARTHUR H. SMITH

Dr. Smith is one of America's ablest representatives at forcign courts. He is not so accredited by the government of this country, but rather chooses to be known as a missionary to China. In this capacity he has learned much of China which in another relation might be denied him. Being a statesman by instinct and genius, he has taken a broad survey of conditions and opportunities and here presents his criticisms of America's strength and weakness abroad.

\section{Ancient Jerusalem}

Illustrated. In press.

HON. SELAH MERRILL.

This work will immediately be recognized as authoritative and well nigh final. Dr. Merrill, as the American Consul, has lived at Jerusalem for many years, and has given thirty-five years of thorough, accurate study and exploration to this exhaustive effort. It contains more than one hundred maps, charts, and photographs.

\section{Palestine Through the Eyes of a Native}

Illustrated, \$1.00 net. GAMAHLIEL WAD-EL-WARD

The author, a native of Palestine, has been heard and appreciated in many parts of this country in his popular lectures upon the land in which so large a part of his life was spent. His interpretation of many obscure scriptural passages by means of native manners and customs and traditions is particularly helpful and informing. 



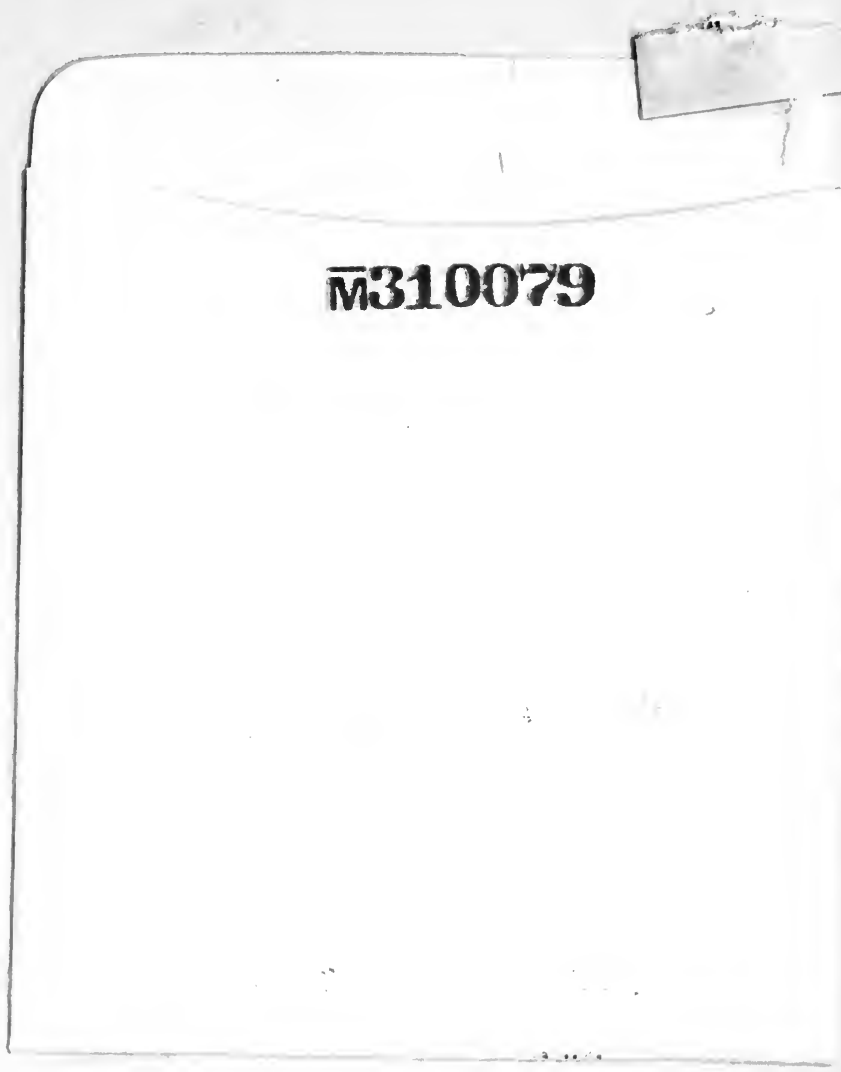


wit?

t. 